\title{
ASSESSING RODENT SPECIES COUNTS AND DIVERSITY IN THE NOT-GRAZED MONTANA DE ORO STATE PARK AND THE ROTATIONALLY GRAZED PECHO RANCH
}

\author{
A Thesis \\ presented to \\ the Faculty of California Polytechnic State University, \\ San Luis Obispo
}

In Partial Fulfillment

of the Requirements for the Degree

Master of Science in Agriculture, with Specializations in Animal Science

by

Nancy Marie Lemos

June 2014 
(C) 2014

Nancy Marie Lemos

ALL RIGHTS RESERVED 


\section{COMMITTEE MEMBERSHIP}

TITLE:

Assessing Rodent Species Counts and Diversity in the NotGrazed Montana De Oro State Park and the Rotationally Grazed Pecho Ranch

AUTHOR: $\quad$ Nancy Marie Lemos

DATE SUBMITTED: June 2014

COMMITEE CHAIR: $\quad$ Dr. Marc Horney, Assistant Professor

Animal Science Department

California Polytechnic State University, San Luis Obispo

COMMITTEE MEMBER: Dr. Priya Verma, Professor

Natural Resources Management and Environmental

Sciences Department

California Polytechnic State University, San Luis Obispo

COMMITTEE MEMBER: Dr. Chip Appel, Professor

Natural Resources Management and Environmental

Sciences Department

California Polytechnic State University, San Luis Obispo 


\begin{abstract}
Assessing Rodent Species Counts and Diversity in the Not-Grazed Montana De Oro State Park and the Rotationally Grazed Pecho Ranch
\end{abstract}

Nancy Marie Lemos

The available data examining the influence of rotational grazing on rodent responses are limited. This study investigated how rotational livestock grazing practices influence small mammal rodent abundances and species diversity. We looked for evidence of variation in the occurrence and/or numbers of certain rodent species among three plant community types (grassland, shrubland, grass-shrub mix), managed with or without grazing. We used Sherman live traps over a total of eight trapping sessions. We totaled 486 trapnights for each of the six plant community and grazing management combinations. The three plant community types were identified by visual cover.

Out of the eight different species we captured, only Peromyscus maniculatus (North American deermouse) and Reithrodontomys megalotis (western harvest mouse) had sufficient captures to be analyzed for differences in abundance. Using all eight species to calculate the Shannon's diversity index for each plot, we found evidence that rodent species diversity is less in grassland habitats than in shrubland habitats or grassland/shrubland mixed habitats $(\mathrm{p}<0.001)$. We observed that the North American deermouse was most common in the not-grazed shrub habitat $(\mathrm{p}<0.05)$. The North American deermouse preferred the not-grazed grassland habitat to the grazed grassland habitat, and the not-grazed shrub habitat to the grazed shrub habitat. The North American deermouse was more prevalent in the grazed grassland/shrubland mixed habitats than the not-grazed mixed habitat. The western harvest mouse preferred the not-grazed grassland habitat to the grazed grassland habitat. Based on our results, the current rotational livestock grazing practices do not influence biological diversity, so no management adjustments are needed. The North American deermouse abundance would benefit from not-grazing management in a grassland community or in a shrubland community, but would benefit from rotationally grazing management in a mixed grassland/shrubland habitat. From a management perspective, the western harvest mouse would benefit from not-grazing in a grassland community, but appears unaffected by grazing in the shrubland and mixed communities.

Keywords: Rodent, Grazing, Peromyscus maniculatus, Reithrodontomys megalotis 


\section{ACKNOWLEDGMENTS}

Thank you PG\&E biologist Sally Krenn of Pacific Gas and Electric for permission to conduct the study within the Pecho Ranch property.

Thank you California State Parks for permission to conduct the study within the Montana de Oro State Park.

Thank you Bob Blanchard, the leaser of Pecho Ranch, for his cooperation and assistance with this project.

Thank you Dr. Marc Horney for being the head of my thesis committee and for the guidance patiently given through the revision process.

Thank you Dr. Priya Verma and Dr. Chip Appel for being on my thesis committee.

Thank you to Professor Michael Hall, Professor Robert Rutherford, and Dr. Brent Hallock for being on my original thesis committee.

Thank you to Professor Jeff Sklar, whom assisted in the statistical approach of the study and provided helpful explanations and insight of the various types of statistical methods utilized in the study.

Thank you to Professor Larisa Vredevoe for allowing me to work under her scientific collecting permit to complete this study.

Thank you to my assistant, Jamie Miller, whom taught me how to trap, mark, and handle the rodents.

Thank you to my family, especially my husband and our parents, who have supported me through the thesis process.

This study was made possible through funds provided by the Headwaters Fund, Pacific Gas and Electric, US Fish and Wildlife Service, California Coastal Conservancy, and the Agricultural Research Institute. 
TABLE OF CONTENTS

Page

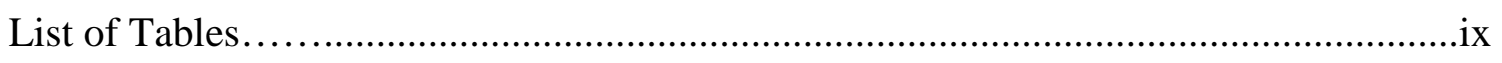

List of Figures...................................................................................................

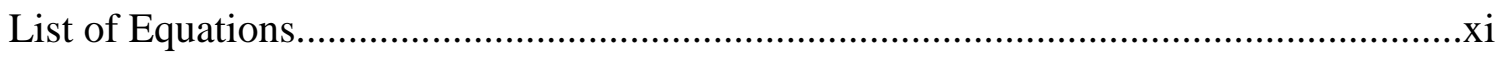

\section{CHAPTER}

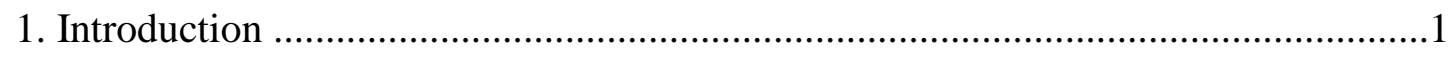

Rodent Ecological Importance....................................................................

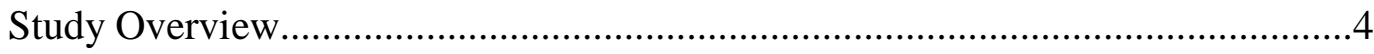

2. Literature Review.........................................................................................

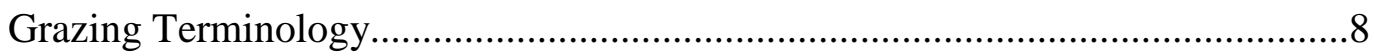

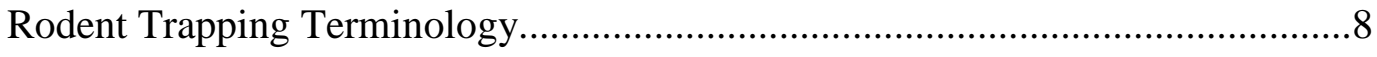

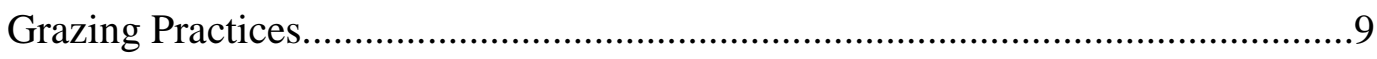

Deferred Grazing.......................................................................................

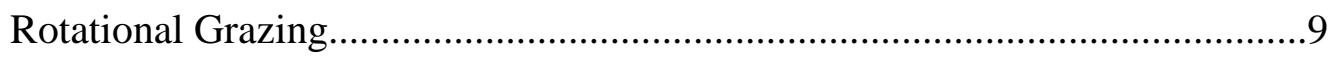

High-Intensity, Short-Duration Grazing..........................................................10

Continuous Grazing......................................................................................11

Scholarly Works of Livestock Grazing Impacts on Rodent Abundance................12

Studies Finding an Increase in Rodent Abundance with Livestock Grazing............................................................................................12

Studies Finding Mixed Rodent Abundance Results with Livestock

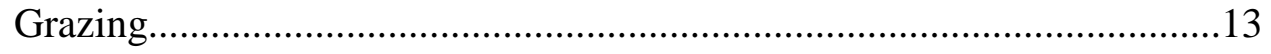


Studies Finding a Decrease in Rodent Abundance with Livestock

Grazing...

Studies Finding Vegetation Influences on Rodent Captures............................15

Methods in the Field.........................................................................................17

3. Materials and Methods....................................................................................19

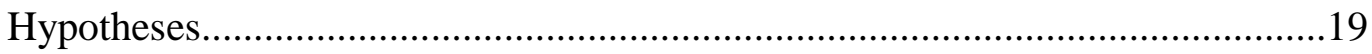

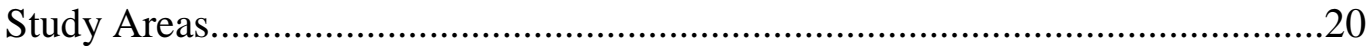

Study Area History ..........................................................................................23

Experimental Design..........................................................................................25

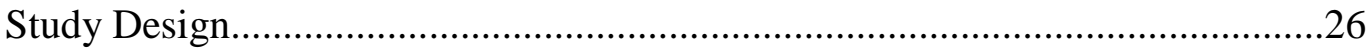

Data Collection Process......................................................................................26

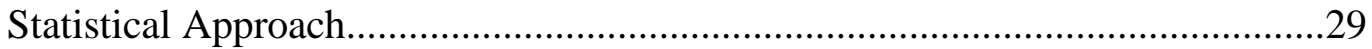

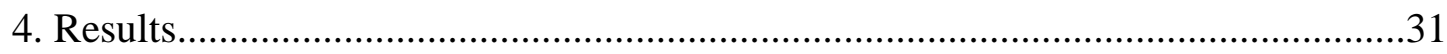

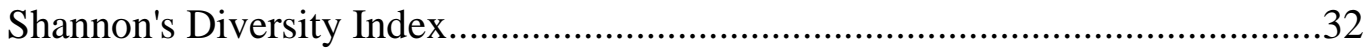

Count Data: Peromyscus Maniculatus (North American Deermouse)...................35

Count Data: Reithrodontomys Megalotis (Western Harvest Mouse).....................40

5. Discussion and Conclusion...............................................................................42

Peromyscus Maniculatus (North American Deermouse)........................................43

Reithrodontomys Megalotis (Western Harvest Mouse)..........................................44

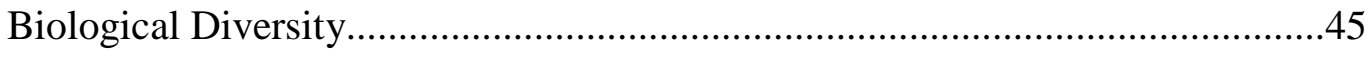

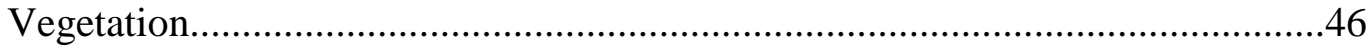

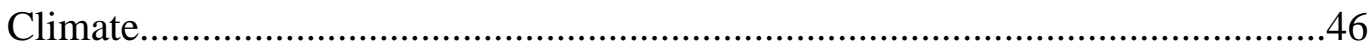

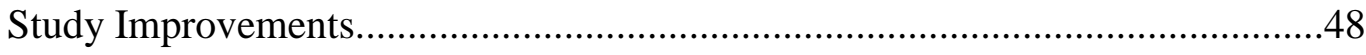

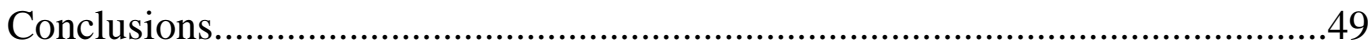


Recommendations.

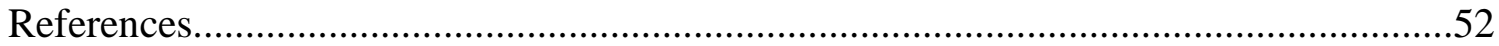

\section{Appendixes}

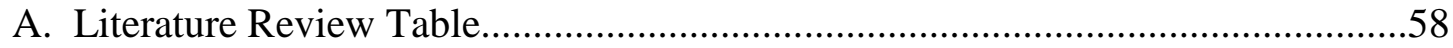

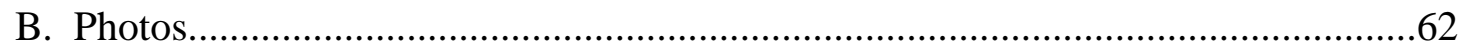

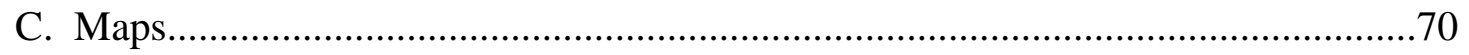

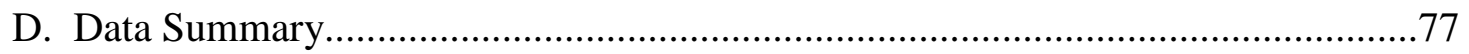

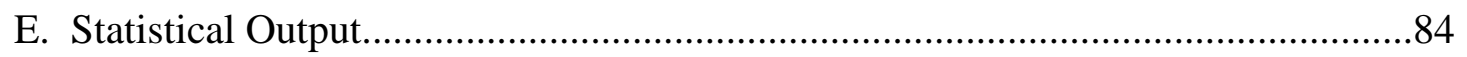




\section{LIST OF TABLES}

Table Page

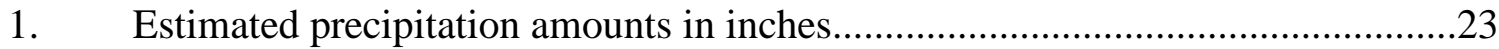

2. Summary of trapping session dates and plot types.......................................28

3. 2-Way ANOVA results with the interaction effect..........................................33

4. 2-Way ANOVA results without the interaction effect.....................................34

5. Tukey comparative analysis of the Shannon's diversity index means...................35

6. Summary of the log linear results for species count data.................................37

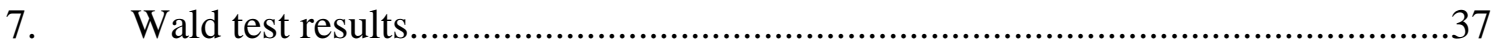

8. Post-hoc comparative analysis of the relationship

between the species count interactions per 486 trapnights..............................39 


\section{LIST OF FIGURES}

Figure $\quad$ Page

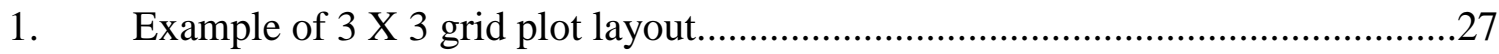

2. Mean Shannon's diversity index for each management/plant community

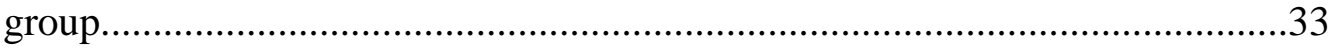

3. Mean Shannon's diversity index for each community and management type.......34

4. Mean number of observed North American deer mouse counts per 486 trapnights for each management/plant community group.............................36

5. Management practice and plant community interaction plot on the number of captures for the species Peromyscus maniculatus....................................38

6. Mean number of observed western harvest mouse counts per 486 trapnights for each management/plant community group............................40

7. Management practice and plant community interaction plot on the number of captures for the species Reithrodontomys megalotis. 


\section{LIST OF EQUATIONS}

Equation Page

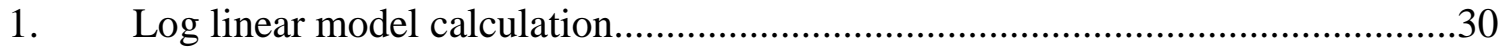




\section{CHAPTER 1}

\section{INTRODUCTION}

Livestock grazing is considered by Bock et al. (1993) to be the most widespread management practice in western North America, occurring on approximately $85 \%$ of the semi-arid and arid lands of the west (Sabadell, 1982). Huntsinger and Stars (2006) estimated that arid and semiarid North America make up more than a third of western North American, and totals approximately one billion hectares of range livestock grazing. Livestock grazing occurs on $31.5 \%$ of the 100 million acres of land in California, including 15 million acres of private land, and 16.5 million acres of public land (Kuminoff et al. 2001).

Since livestock grazing is a common land use, it has the potential to affect wildlife, including rodents. According to Wilson and Reeder (2005), rodents comprise $42 \%$ of the mammal species living in the world. Since a variety of animals consume rodents, and a disturbance effecting rodent diversity may also affect their predator diversity (Owen, 1988), it is possible that rodent responses to cattle grazing can impact other trophic levels. Previous small mammal studies suggest that rodents are sensitive to habitat alterations (Sauvajot et al., 1998; Sullivan and Sullivan, 2001). This study strives to increase understanding of the livestock grazing influence on small mammals within a rotational grazing management system. The specific research question addressed is: 
Does rotational livestock grazing benefit or harm rodent abundance and diversity when compared to an adjacent not-grazed area?

\section{Rodent Ecological Importance}

Rodents consume a variety of foods. For example, Jameson (1952) has documented the diet of a deer mouse (Peromyscus maniculatus) to include seeds, fruits, leaves, arthropods, fungi, birds and other mice. Batzli and Pitelka (1971) documented grass stems, grass leaves, grass seeds, and green forbs in the California vole (Microtus californicus) diet. Both studies observed seasonal differences in the diet of the rodents (Batzli and Pitelka, 1971; and Jameson, 1952). Northern flying squirrels (Glaucomys sabrinus) and two species of deer mice (Peromyscus maniculatus and Peromyscus keeni) have been documented as predators on bird eggs and nestlings (Bradley and Marzluff, 2003).

Rodents are considered to be one of the main herbivores in range ecosystems that have a direct impact on the vegetation (Holechek et al. 2004). Herbivores reduce shrubs through browsing and indirectly affect herb cover and seed densities by opening up areas under shrubs and/or modifying physical and chemical conditions of the soil (Holechek et al. 2004). Rodents also increase the probability of seedling establishment through harvesting seeds (Longland et al., 2001).

Small mammals can influence vegetative succession and species composition. Weltzin et al. (1997) demonstrated how the black-tailed prairie dog (Cynomys ludovicianus) prevents woody succession of a grassland and savannah environment by removing the honey mesquite (Propsopis glanulosa) pods. They found that honey 
mesquite seed and pod disappearance was 3-99\% greater within the black prairie dog colonies than in areas where prairie dogs were excluded (Weltzin et al. 1997). In another study, Heske et al. (1993) observed greater species diversity of summer annual dicots on plots where kangaroo rats (Dipodomys sp.) were present, but was uncertain if this observation was caused by the kangaroo rat activities or as a consequence of the increase in grass cover.

Rodents are a key prey species for many predators, including raptors, snakes, foxes, bobcats, and coyotes. Preston (1990) observed that five species of rodents comprised 82\% (by frequency) of the diet of Red-tailed Hawks (Buteo jamaicensis), and at least $40 \%$ of the diet of Northern Harriers (Circus cyaneus). Filippi et al. (2005) observed that rodents comprised $66.7 \%$ of the diet for the four-lined snake (Elaphe quatuorlineata). Fitch and Twining (1946) examined the contents of Pacific rattlesnake (Crotalus viridis oreganos) stomachs, and observed rodent remains in $68.97 \%$ of the 87 stomachs. Lanszki et al. (2002) analyzed red fox (Vulpes vulpes) scats over a period of four years and determined that rodent remains comprised $68 \%$ of the mean biomass. Neale and Sacks (2001) examined bobcat (Lynx rufus) scat for five seasons and detected rodent remains the most frequently, with seasonal totals ranging from $40.9 \%$ to $58.6 \%$ of occurrences. Neale and Sacks (2001) also studied coyote (Canis latrans) scat, and detected rodent remains in 15.9 to $36.7 \%$ of the total seasonal observations.

Small mammals create burrows and shelters that also provide habitat for other animals. Burrows of California ground squirrels (Spermophilus beecheyi) are an important habitat for both juvenile and adult California tiger salamanders (CTS), Ambystoma californiense (Loredo et al., 1996). Loredo et al. (1996) observed 59 CTS 
adults and 68 CTS juveniles and found that $83 \%$ of the adults and $54 \%$ of the juveniles utilized California ground squirrel burrows upon emigrating from a breeding pond. Davidson et al. (2008) observed a 2 to 4 fold increase in lizard abundance on the mounds and burrow systems of the prairie dog (Cynomys gunnisoni) and banner-tailed kangaroo rat (Dipodomys spectabilis) when compared to areas without mounds and burrow systems. Whitford and Steinberger (2010) observed more than 40 arthropod taxa in the stick houses created by two species of packrats, Neotoma albigula and Neotoma micropus.

Rodents are important to study because of their influence on ecosystem characteristics. Their presence or absence can influence bird fledgling success (Bradley and Marzluff, 2003), successful germination of plants (Longland et al. 2001), woody succession (Weltzin et al. 1997), and plant diversity (Heske et al. 1993). Rodents are a key prey species and can greatly impact the food chain and affect many carnivores (Preston, 1990; Filippi et al. 2005; Fitch and Twining, 1946; Lanszki et al., 2002; Neale and Sacks, 2001). Rodents create shelters and burrows that are used by California tiger salamanders (Loredo et al., 1996), lizards (Davidson et al., 2008), and arthropods (Whitford and Steinberger, 2010). If the presence of rotational livestock grazing or absence of grazing does affect rodents, the management system has potential to affect other ecosystem conditions as well.

\section{Study Overview}

Our purpose was to better understand how rotational livestock grazing practices influence small mammal species diversity. This was accomplished by conducting 
simultaneous surveys of small mammals on land managed by a rotational grazing system and on adjacent not-grazed land with similar plant communities. Results were analyzed for differences in species diversity and population counts among management type and plant community combinations. The two management strategies are "grazed" and "notgrazed." Three broad plant community types were defined for sampling purposes. "Grasslands” represented plant assemblages where less than 25\% of the vegetation were shrubs, and more than $75 \%$ were grasses and forbs. "Mixed" communities contained approximately 50\% shrubs and 50\% grasses and forbs. "Shrub" communities were defined as those where $75 \%$ of the vegetation consisted of shrubs and less than $25 \%$ of the vegetation consisted of grasses and forbs.

This observational study had three objectives.

1) Determine if the six factors (three plant community types and two management practices) produce differences in rodent species captures and/or Shannon's diversity index.

2) Determine if rodent species captures vary by plant community as determined by species captures and/or Shannon's diversity index.

3) Determine if rodent species captures differ by management practice as determined by species captures and/or Shannon's diversity index.

Based on the field guide created by Kays and Wilson (2002), we expected to find ten rodent species in the habitats within the study area, including Peromyscus maniculatus, Thomomys bottae, Rattus rattus, Rattus norvegicus, Chaetodipus californicus, Neotoma fuscipes, Neotoma lepida, Peromyscus californicus, 
Reithrodontomys megalotis, and Microtus californicus. The hypotheses under investigation are:

1) We expect to find Peromyscus maniculatus, Thomomys bottae, Rattus rattus, and Rattus norvegicus equally in all three plant community types since they are reported in the field guide as being commonly found in all habitat types. We do not know how grazing impacts these four species, so we assume that they will be equally represented in both the grazed and not-grazed areas.

2) We expect to find Chaetodipus californicus, Neotoma fuscipes, Neotoma lepida, Peromyscus californicus more often in the shrubland community since they are reported in the field guide as occurring in coastal scrub habitat. We do not know how grazing impacts these four species, so we assume that they will be equally represented in both the grazed and not-grazed areas.

3) We expect to find Reithrodontomys megalotis and Microtus californicus more often in the grassland community since they are reported in the field guide as being commonly found in grassland habitat. We do not know how grazing impacts these two species, so we assume that they will be equally represented in both the grazed and not-grazed areas.

4) We expect to find greater rodent species diversity in the shrubland community since there are two more rodent species in the study area that prefer shrubland habitat to grassland habitat. We do not know how grazing will impact biological diversity, so we assume that they will be equally represented in both the grazed and not-grazed areas. 


\section{CHAPTER 2}

\section{LITERATURE REVIEW}

A search of the published literature on rodents and livestock grazing produced 16 scholarly works dedicated to small mammal ecology and the environmental impacts of livestock grazing practices. Of those, seven studies found variation in species and numbers of rodents depending on whether sites were managed by livestock grazing or if they were not grazed. We organized the studies based on the authors finding an increase, decrease, or both in their rodent abundance results with regard to the presence of livestock grazing. Most authors gave very limited details of the grazing management system used in their studies. Some only provided the name of the grazing system they used such as “deferred," “rotational," or “continuous” and did not include any other details. Some authors provided grazing duration, stocking density, or the number and type of animals they used. We categorized these scholarly works based upon the details they provided. This literature review discusses grazing and rodent trapping terminology, followed by a description of grazing practices utilized within the seven scholarly works. We then discussed the impacts on rodent abundance within the seven studies, categorizing those studies by 1) those studies that found an increase in rodent abundance with livestock grazing, 2) studies finding mixed rodent abundance results with livestock grazing, and 3) studies finding decreases in rodent abundance with livestock grazing. 
Lastly, we discuss the studies that found vegetation influence on rodent captures and compared trapping methods used in the seven studies. Tables summarizing these scholarly works in this literature review are in Appendix A.

\section{Grazing Terminology}

Grazing terminology is from Bedell (2005). An animal-unit (AU) is described as one mature cow of about 1,000 pounds (450 kg), either dry or with calf up to 6 months of age. This animal would consume about 26 pounds (12 kg) of forage/day on an oven-dry basis. An animal-unit-equivalent (AUE) is a number that relates the amount of forage a particular kind or class of animal consumes on an oven-dry basis, relative to one AU. An animal-unit-month (AUM) is the amount of oven-dry forage one animal consumes for 30 days.

\section{Rodent Trapping Terminology}

The Sherman trap is an aluminum box-trap with an open door at one end leading to a weight-sensitive treadle that closes the spring-loaded door. Small Sherman live traps measure $5.1 \mathrm{~cm}$ x $6.4 \mathrm{~cm}$ x $16.5 \mathrm{~cm}$. Medium Sherman live traps measure $7.6 \mathrm{~cm}$ x 8.9 cm x $22.9 \mathrm{~cm}$ (photos 7, 8, and 14 in Appendix B). Trapping grids are square or rectangular in shape and traps are spaced evenly along the lines, but traplines also run inside the square or rectangle (Jones et al., 1996). A trapline, also called transect line, is a sampling technique where traps are spaced evenly along a line (Jones et al., 1996). Trapnights are the number of traps multiplied by the number of daily trapping periods (Jones et al., 1996). A drift fence is a barrier designed to direct small mammals into traps (Jones et al,. 1996). A live pitfall trap is a smooth-walled container with its open-end 
flushed to the surface and placed in the ground at least $40 \mathrm{~cm}$ deep so that the animals cannot escape by jumping out of the container (Jones et al., 1996). The animals are captured when they fall through the opening into the container.

\section{Grazing Practices}

Three different types of grazing practices were described in the seven scholarly works presented in this literature review: "deferred." "rotational," and "continuous." Kothmann (2009) and Holechek et al. (2004) provided descriptions of these three grazing management practices.

\section{Deferred Grazing}

According to Kothmann (2009), deferred grazing is the cessation of grazing for a continuous period during the growing season in order for the livestock-preferred plant species to reach reproductive maturity. The deferment may be as short as 60 days or longer than a year, depending on the environment and the vegetation. When a grazed area is under deferment, preferred plants and patches that have experienced more grazing activity than other areas have an opportunity to recover. In addition, deferment can be set to increase a particular species' population or its biomass. In a deferred system, there are at least two pastures. One pasture is not grazed for the length of deferment and the other

pastures are grazed. More than one pasture can suspend grazing at the same time (Holechek et al., 2004), provided there is another location for the livestock.

\section{Rotational Grazing}

Rotational grazing is the action of keeping livestock in paddocks/pastures for a time and then moving the animals into another paddock/pasture when the conditions are 
suitable. These conditions depend on the livestock manager, but a few reasons to move into a new pasture are low quality and/or quantity of feed, manager preference, and limitations on drinking water. Rotational grazing has more management variables than deferred or continuous grazing. According to Kothmann (2009), rotational grazing practices are defined in terms of four characteristics that are set by the manager: 1) stocking density, 2) number of paddocks per herd, 3) length of rest periods, and 4) length of grazing periods.

An advantage of having a more highly concentrated group of animals is that the available forage will be grazed more uniformly than a less concentrated group (Kothmann, 2009). However, a less concentrated group can be more selective about what they eat and may return to preferred plants multiple times, while other plants are not eaten.

When the animals are moved into another paddock, the vegetation in the previously used paddock has an opportunity to grow and rest from other livestock impacts (Kothmann, 2009). The length of rest depends on how long the livestock graze in the other paddocks, the total number of paddocks, and seasonal conditions. Seasonal conditions also impact resting periods. Favorable seasonal conditions such as water and sunlight will encourage vegetation growth (George et al., 1985), allowing the plants to be ready for grazing sooner than during seasonal conditions that disfavor plant growth (e.g. drought) (Kothmann, 2009).

\section{High-Intensity, Short-Duration Grazing}

High-intensity, short-duration (HISD) grazing is a type of rotational grazing that is also referred to as short-duration grazing, rapid-duration grazing, time-control grazing, 
and cell grazing (Holechek et al., 2004). Five principles typically describe HISD grazing: 1) the management is flexible without a set schedule, 2) stock density is high, 3) the grazing periods during the growing season are short, lasting from 1-5 days, 3) resting periods last 30 to 60 days, 4) and there is a fencing layout (Holechek et al., 2004; Savory and Parsons, 1980).

High-intensity, short-duration grazing generally refers to a large number of livestock (high density) contained in an area for a brief amount of time (short duration). As defined by Holechek et al. (1998) grazing intensity refers to the effects that grazing animals have on rangelands for a particular time period. High-intensity can be achieved by concentrating animals with high enough stocking rates to heavily graze the vegetation (Smith, 2012). Holechek and Galt (2000) defined heavy grazing intensity as "51-60 percent of forage by weight have been utilized, nearly all primary forage plants show grazing on key areas, palatable shrubs show hedging, key areas show a lack of seed stalks, and grazing is noticeable in areas over 1.5 miles from water." In comparison, four other grazing intensity categories-1) non-use to light grazing utilizes 0-30 percent of forage by weight, 2) conservative grazing utilizes 31-40 percent of forage by weight, 3) moderate grazing utilizes 41-50 percent of forage by weight, and 3) severe grazing utilizes $61+$ percent of forage by weight.

\section{Continuous Grazing}

Holechek et al. (2004) defines continuous grazing as keeping a herd of livestock in an area throughout a year or during the time of year that grazing is feasible. It is the easiest type of grazing management because there is minimal animal handling and decisions focus on stocking density (Kothmann, 2009). The livestock have access to the 
entire area and do not need to be moved until grazing is no longer possible. Livestock gather around areas where water, vegetation, and shade are nearby, which can cause uneven use of the pasture (Holechek et al., 2004). Since the livestock have a large area to graze, they tend to be more selective in the plants they consume, which can reduce forage quality over time (Holechek et al., 2004; Kothmann, 2009). However, over the short term, livestock gain weight quickly since they are consuming the highest quality plants they can find. Overtime, the favorite plants are grazed more often than their resources can be replenished and the plants die. Once the livestock have reduced the forage quality from frequently grazing their favorite plants or in their favorite places, animal performance can decline (Kothmann, 2009).

\section{Scholarly Works of Livestock Grazing Impacts on Rodent Abundance}

There are seven studies where we found variation in species and numbers of rodents when comparing sites managed by livestock grazing with sites that were not grazed. We organized the studies based on the author(s) finding an increase, decrease, or mixed results in their rodent abundance results with regard to the presence of livestock grazing.

\section{Study finding An Increase in Rodent Abundance with Livestock Grazing}

Powers et al. (2011) observed an increase in rodent abundance in response to livestock grazing, but they were only searching for signs of pocket gophers (Thomomys monticola and T. Bottae). They compared pocket gopher densities in 21 ungrazed sites with 21 grazed sites from June to July 2009 in the central Sierra Nevada Mountains, California. The sites varied in size from 4 to 60 hectares (ha) and were grazed by cattle from July through September. During those months, the cattle removed $40-60 \%$ of the 
herbaceous biomass produced that year. The number of cattle that grazed the study area was not included in the report, so stock density is not known. The authors observed that pocket gopher density increased by 14.3 pocket gophers per ha in the grazed sites over the ungrazed sites.

\section{Studies Finding Mixed Rodent Abundance Results with Livestock Grazing}

Bock et al. (1984), Bueno et al. (2012), and Jones et al. (2003) and reported that the abundance of rodents varied by species in how they responded to grazing in their habitat. The rodent responses were observed in different habitat types. Jones et al. (2003) trapped in grassland and mesquite oak savannah in southeastern Arizona. Bueno et al. (2012) did not provide habitat information, but trapped in Alberta, Canada. Bock et al. (1984) trapped in semi-desert grassland in southeastern Arizona.

Jones et al. (2003) and Bock et al. (1984) did not describe the type of grazing system utilized. In Jones et al. (2003), the stocking density averaged about one AU per 25 ha. Bock et al. (1984) described their grazing treatment as one AU per 10 ha. Bueno et al. (2012) compared ungrazed areas with areas managed by continuous grazing, but did not provide stocking density. These three studies all involved cattle grazing.

Bueno et al. (2012) trapped deer mice and meadow voles before and after grazing treatments. Deer mice (Peromyscus maniculatus) and meadow vole (Microtus pennsylvanicus) captures did not differ among the sites prior to grazing. After grazing, deer mice were captured twice as often in the grazed area than in the non-grazed area, and meadow voles were captured 25 times more often in the ungrazed plots than in the grazed area.

Bock et al. (1984) observed that one small mammal species (Merriam kangaroo rat, Dipodomys merriami) was captured approximately 18 times more often on the grazed 
section, while five other species (hispid pocket mouse, Perognathus hispidus; western harvest mouse, Reithrodontomys megalotis; white-footed mouse, Peromyscus leucopus; southern grasshopper mouse, Onychomys torridus; and hispid cotton rat, Sigmodon hispidus) were trapped approximately 2.4, 6.5, 1.9, 5.25, and 2.4 times, respectfully more often in the non-grazed section. In addition, the capture numbers of two other mice species (silky pocket mouse, Perognathus flavus; and the deer mouse, Peromyscus maniculatus) did not differ among treatments.

Jones et al. (2003) observed that 36\% of mice species from the Muridae family (Baiomys taylori, Sigmodon fulviventer, Reithrodontomys fulvescen, and R. megalotis) were trapped $69 \%$ more often in the ungrazed sites. Heteromyidae family members (Chaetodipus penicillatus, Chaetodipus baileyi, Perognathus favus, Chaetodiptus hispidus, and Dipodomys merriami) were trapped 27\% more often in the grazed sites.

\section{Studies Finding a Decrease in Rodent Abundance with Livestock Grazing}

All three of the authors that observed a decrease in rodent abundance in response to livestock grazing pooled their rodent capture data (Bock et al., 2006, Chapman and Ribic, 2002; and Rosenstock, 1996) Two of these authors conducted abundance analysis because their capture sizes were too small to test individual species' responses (Rosenstock, 1996; Bock et al., 2006). The reduced rodent responses in grazed areas were observed in shrubland/grassland habitat in southcentral Utah (Rosenstock, 1996), perennial bunchgrass/shrub habitat in southeastern Arizona (Bock et al., 2006), and in riparian grass/forb habitat in southwestern Wisconsin (Chapman and Ribic, 2002).

Grazing management and stock density greatly differed among all three studies. In the Rosenstock (1996) study, there was deferred grazing management with a stocking density of 1 AU per 165.5 ha, which is low. The length of the deferment period was not 
described. Rosenstock (1996) compared differences at the patch scale (1ha) and at the macrohabitat scale (100 ha). In Chapman and Ribic's (2002) study, there were two types of grazing management: continuous grazing with a stocking density of one AU per 1 to 2.6 ha, and managed intensive rotational grazing (MIRG) with a stocking density of one AU per 0.02 ha. In the Bock et al. (2006) study there was rotational grazing management on two ranches with a stocking density of one AU per 17 ha on one ranch, and one $\mathrm{AU}$ per 12 ha on the other ranch. Despite the different grazing managements, total rodent abundance was consistently lower in the grazed areas than the non-grazed areas. Bock et al. (2006) and Rosenstock (1996) had used cattle in their study, while Chapman and Ribic (2002) did not describe the type of livestock in their study.

Chapman and Ribic (2002) observed 1.4 to 2.3 times more species and 3 to 5 times greater small mammal abundance on the non-grazed buffer sites than on the MIRG pastures. They observed an average of 1.4 to 2.9 times more small mammal species and an average of 4.3 to 7 times more small mammal abundance on the non-grazed buffer areas than on the continuously grazed pastures (Chapman and Ribic, 2002). The MIRG and continuous grazed pastures did not differ in total abundance (Chapman and Ribic, 2002). Bock et al. (2006) found an average of $34 \%$ more total abundance in the ungrazed areas as compared to the grazed areas. Rosenstock (1996) observed that the ungrazed sites in the macrohabitat contained $80 \%$ more small mammals in the ungrazed sites than the grazed sites. This leads to the question, "What was it about the grazed pastures that may have produced this difference in rodent abundances?"

\section{Studies Finding Vegetation Influences on Rodent Captures}

Rosenstock (1996) and Bock et al. (2006) both measured vegetation height in their plots and found taller vegetation in the non-grazed areas than in the grazed areas. On 
the other hand, Jones (2003) did not observe a difference in vegetation height. Bock et al. (2006) observed a positive correlation with total abundance and vegetation height, but unfortunately did not include the quantity of that correlation. Rosenstock (1996) also observed that ungrazed patches and macrohabitats had taller perennial grass (mean difference $9.5 \mathrm{~cm}$ and $21.27 \mathrm{~cm}$, respectfully) than the grazed area. Powers et al. (2011) observed $37.3 \%$ taller on average maximum vegetation height than the grazed sites.

Plant litter, ground cover, and canopy cover differed among the grazed areas and the non-grazed areas. Jones (2003) observed 48\% more bareground in the grazed area than in the non-grazed area and a 35.4\% more grass canopy in the non-grazed area than in the grazed area. Rosenstock (1996) observed that ungrazed patches and macrohabitats had more perennial grass (mean difference 7.9\% and 7.27\%, respectfully) and litter cover (mean difference $6.62 \%$ and $2.36 \%$, respectfully) than in the grazed area. Bock et al. (1984) observed $45 \%$ more grass cover and $25.3 \%$ more woody plants than the grazed pasture. Powers et al. (2011) observed that the ungrazed sites had 27.1\% more cover and $67 \%$ thicker thatch than the grazed sites on average. These results suggest that vegetation characteristics contribute to habitat selection among rodents.

Jones et al. (2003) found that total Heteromyidae captures were positively correlated with the amount of unvegetated ground (correlation coefficient $=0.54$ ). They also reported a negative correlation between the unvegetated ground and percentage of captures consisting of the Muridae family, excluding the Peromyscus genus (correlation coefficient $=-0.76)$. Powers et al. (2011) found a negative correlation between pocket gophers and vegetation cover (correlation coefficient $=-0.45$ ) and pocket gophers and thatch height (correlation coefficient $=-0.66$ ) in ungrazed sites. These relationships 
suggest that rodents are responding to the plant characteristics that are associated with the presence or absence of grazing. Herbivores consume the vegetation, and as the plant height, canopy, or litter cover changes, rodents may become more prevalent or less prevalent depending upon their individual habitat preference.

\section{Methods in the Field}

Common rodent trapping methods are traplines (Bock et al., 2006; Chapman and Ribic, 2002; Bock et al., 1984; Jones et al., 2003) or grids (Rosenstock, 1996; Bueno et al., 2012). Most small mammal trappers utilized Sherman live traps in their study (Bock

et al., 2006; Chapman and Ribic, 2002; Rosenstock, 1996), although Chapman and Ribic (2002) also used drift fences with pitfall traps. Trap station spacing and trap bait varied among researchers. Some trap stations were spaced 10-meters apart (Powers et al., 2011; Jones et al., 2003), others were spaced 5 or 6 meters apart (Bock et al., 2006; Rosenstock, 1996), 20-meters (Bock et al., 1984), or up to 30-meters apart (Chapman and Ribic, 2002).

Bait also varied among the trappers, with some having a mixture of bait types including birdseed, grains, and seeds (Bueno et al., 2012; Rosenstock, 1996), but the most common bait was rolled oats as part of a mixture or on its own (Jones et al., 2003; Bock et al., 1984; Rosenstock, 1996; Bock et al., 2006). Cotton or synthetic cotton was the most common bedding material (Bock et al., 2006; Bueno et al., 2012; Jones et al., 2003). Marking was done by one of three methods: metal ear tag (Bueno et al., 2012; Chapman and Ribic, 2002; Rosenstock, 1996), ink (Bock et al., 2006), or clipping guard hairs (Jones et al., 2003).

Bock et al. (2006), Bueno et al. (2012), and Jones et al. (2003) and trapped for three consecutive nights. Bock et al. (2006) began trapping for four consecutive nights, 
but switched to three nights because they were not capturing new rodents after three nights. Chapman and Ribic (2002) trapped for 5 consecutive nights. Rosenstock et al. (1996) trapped for four consecutive nights.

Time of trapping in relation to the presence or absence of livestock varied among the trappers. Most studies did not include the elapsed time that trapping occurred since the last grazing event (Bock et al., 2006; Jones et al., 2003; and Rosenstock, 1996). Trapping occurred immediately before and after rotational grazing in the Chapman and Ribic (2002) study. Bock et al. (2006) trapped when cattle were present during one winter season, but the time since grazing occurred in the other trapping sessions is unknown. Powers et al. (2011) conducted surveys one month before the onset of livestock grazing and nine months since the grazing event. Bock et al. (1984) and Bueno et al. (2012) trapped before the onset of grazing and also during grazing.

The most common methods of trapping among the studies include the following methods: 1) the use of traplines spaced 5 or 6 meters apart, 2) the use of rolled oats as bait, 3) the use of cotton or synthetic cotton as bedding material, 4) the use of metal ear tags for marking captures, 5) and trapping for 3 consecutive nights for each trapping session. 


\section{CHAPTER 3}

\section{MATERIALS AND METHODS}

\section{Hypotheses}

Our four hypotheses were:

1) Peromyscus maniculatus, Thomomys bottae, Rattus rattus, and Rattus norvegicus are reported in the field guide as being commonly found in all habitat types; therefore, we expect to find them equally in all three plant community types. We do not know how grazing impacts these four species, so we assume that they will be equally represented in both the grazed and not-grazed areas.

2) We expect to find Chaetodipus californicus, Neotoma fuscipes, Neotoma lepida, Peromyscus californicus more often in the shrubland community since they are reported in the field guide as occurring in coastal scrub habitat. We do not know how grazing impacts these four species, so we assume that they will be equally represented in both the grazed and not-grazed areas.

3) We expect to find Reithrodontomys megalotis and Microtus californicus more often in the grassland community since they are reported in the field guide as being commonly found in grassland habitat. We do not know how grazing impacts these two species, so we assume that they will be equally represented in both the grazed and not-grazed areas. 
4) We expect to find greater rodent species diversity in the shrubland community since there are two more rodent species in the study area that prefer shrubland habitat to grassland habitat. We do not know how grazing will impact biological diversity, so we assume that they will be equally represented in both the grazed and not-grazed areas.

\section{Study Areas}

We tested the hypotheses by trapping rodents in a rotationally grazed area and a not-grazed area. The not grazed area (NGA) was located in Montana de Oro State Park, north of Coon Creek in San Luis Obispo County, California. Montana de Oro State Park prohibits livestock grazing. The grazed area (GA) was located in Pecho Ranch owned by Pacific Gas and Electric Company (hereafter referred to as "PG\&E”), located south of Coon Creek and adjacent to Montana de Oro State Park. Maps of the GA and the NGA

are in Appendix C. Since November 1, 1990, the Blanchard family has had a grazing lease/license agreement on 3358 acres of Pecho Ranch to graze cattle, goats, and sheep (Pacific Gas and Electric Company, 2006). Horses are also known to graze on Pecho Ranch (Macon and Dagget, 2000).

The livestock manager describes grazing management as high-intensity, shortduration (Macon and Dagget, 2000), but we were not able to obtain enough grazing management information to support this claim. However, we have enough information to classify the grazing management as rotational grazing. We could classify the grazing management as high-intensity short duration if we had a record during the time of the study of high stocking density, grazing periods lasting one to five days, and resting 
periods lasting 30 to 60 days during the growing season (Holechek et al., 2004; Savory and Parsons, 1980).

In 1992, the Blanchard family implemented what they described as a highintensity short-duration grazing management strategy (Macon and Dagget, 2000). The Pecho Ranch is divided into 25 pastures and the entire herd grazes a pasture for several days, creating a brief intense impact on the rangeland vegetation; then the pasture is rested for 45 to 60 or more days. The timing and duration of grazing is dependent on the amount of forage, the type of forage, the time of the year, and moisture availability. The grasslands and shrublands are each grazed 2-3 times per year, although goats are more often used in the shrublands than the cattle. The cattle are occasionally fed hay in a confined area to break down old brush and encourage new brush and perennial grass growth (Macon and Dagget, 2000).

Fry (1992), in his Pecho Ranch Grazing Capacity report for Diablo Canyon estimated the carrying capacity for a 12-month grazing season to be 132 animal units (AU), or 1,584 animal unit months (AUMs). Fry recommended reducing that by $20 \%$ (105.6 AU) during drought years and allowing increases of up to 20\% (158.4 AU) during above average rainfall years. The carrying capacity and stocking density are unknown for the duration of the study, but we can estimate them if we assume that there are $30 \%$ more AU (Macon and Dagget, 2000) than estimated in the Fry (1992) publication. That means that the carrying capacity would be around $172 \mathrm{AU}$ in a normal year, $137 \mathrm{AU}$ during a drought year; and 206 AU during an above average rainfall year. The stocking density would by one AU per 7.9 ha in a normal year, one AU per 9.9 ha during a drought year, and one AU per 6.6 ha during an above average rainfall year. 
The study area was characterized by a climate that is described as Mediterranean. Mediterranean climates have mild, wet winters and hot, dry summers (Holechek et al. 2004). The average precipitation for the area is 16.74 inches according the Western Regional Climate Center (no date) at the Morro Bay Fire Department weather station. This station is located approximately six miles southwest of the Montana de Oro State Park. Most of the precipitation occurs from October through April months. Monthly high temperatures average in the low 60's during the winter and upper 60's during the summer (Western Regional Climate Center, no date).

Rapid plant growth occurs when water is present and temperatures are above 45 degrees Fahrenheit. Since temperatures are in the 60's year round at the study site, conditions for plant growth are dependent upon precipitation. Plants germinate after the first rains of the season (George et al., 1985) and vegetation growth continues until there is no more available moisture in the soil. Table 1 demonstrates the precipitation levels during the time of the study. Based on the available precipitation and temperatures, the growing seasons during the study were from November 2006 through April 2007, January 2008 through April 2008, and began in November 2008 continuing through the duration of the study in February, 2009. 
Table 1. Estimated precipitation amounts in inches. Data were from the Western Regional Climate Center (no date) "Morro Bay Fire Department" station during trapping sessions. February 2008 data were not available, so data from the "San Luis Obispo Polytech" station were included, which is located about 13 miles east of Montana de Oro State Park. Bold numbers indicate months when trapping occurred.

\begin{tabular}{|c|c|c|c|c|}
\hline & & Water & Year & \\
\hline Month & 06-07 & 07-08 & 08-09 & Average \\
\hline October & 0.1 & 0.69 & 0.2 & 0.72 \\
\hline November & 0.49 & 0.0 & 1.0 & 1.69 \\
\hline December & 1.84 & 0.39 & 1.58 & 2.66 \\
\hline January & 1.26 & 7.0 & 0.73 & 3.29 \\
\hline February & 2.42 & 2.75 & 4.89 & 3.43 \\
\hline March & 0.38 & 0.03 & & 2.95 \\
\hline April & 0.69 & 0.56 & & 1.21 \\
\hline May & 0.06 & 0.0 & & 0.34 \\
\hline June & 0.0 & 0.0 & & 0.07 \\
\hline July & 0.0 & 0.0 & & 0.03 \\
\hline August & 0.29 & 0.03 & & 0.06 \\
\hline September & 0.0 & 0.0 & & 0.28 \\
\hline Total & 7.53 & 11.45 & 8.4 & 16.73 \\
\hline
\end{tabular}

\section{Study Area History}

Montana de Oro State Park and Pecho Ranch were part of the Mexican Land Grant Osos y Pecho y Islay. The Osos y Pecho y Islay Land Grant (hereafter referred to as 'Land Grant”) was granted on December 1, 1842 to Victor Linares (Jesperson, 1939). The Land Grant was also granted to Francisco Dadillo in 1843 and to James, Scott, and John Wilson in 1845. Ranchos were large and rancheros lived in a feudal state, with thousands of cattle grazing in the hills and many retainers administering to their wants or tending to their herds. Within fifty years, many rancheros lost all or nearly all of their holdings due to one or more of the following reasons: 1) interest on borrowed money, 2) 
taxation by the state government, 3) proving title to their lands before the U.S. Commission and Courts, and 4) massive cattle herd deaths during the drought of 1863 to 1864. The land was surveyed and patented on September 23, 1869 with an area of 32,430.70 acres (Jesperson, 1939). Estates were cut up into smaller tracts and passed to other owners including Mrs. Ramona Hillard, W.H. Patterson, and K.M. and H.M. Warden.

In 1892, Alden Bradford Spooner leased 6,500 acres of the property and began a farming and dairy business and raised livestock (Jesperson, 1939; Morrison and Haydon, 1917). In 1902, Spooner purchased the 6,500 acres and continued to add surrounding acreage until 1917. By 1917, he had accumulated 8,800 acres from Diablo Canyon to Hazard Canyon including six miles of ocean frontage (Jesperson, 1939; Morrison and Haydon, 1917; Sullivan, 2008). Spooner organized the Pecho Ranch and Stock Company, which involved raising, buying, selling, and dealing with livetock (Jesperson, 1939; Morrison and Haydon, 1917). Spooner ran 500 head of cattle on his ranch, raised a large number of hogs, had Holstein dairy cows, and fine bred horses (Jesperson, 1939; Morrison and Haydon, 1917; and Sullivan, 2008). The Pecho Ranch was known for blooded livestock and for its winter pea production. Spooner also raised barley, hay, and wheat (Jesperson, 1939).

The Pecho Ranch and Montana de Oro State Park continued under Spooner ownership until 1963, when approximately half of Pecho Ranch (4,441 acres) was purchased by the State of Califonia and became known as Montana de Oro State Park (Gates and Bailey, 1982). Pacific Gas and Electric Company currently owns the Pecho Ranch. The Pecho Ranch continues to be grazed under a grazing lease held by Robert 
Blanchard. Prior to the establishment of the state park, the coastal bench lands were used for military exercises for a short period. The Montana de Oro State Park was grazed until the early 1970s (Soreng and Keil, 2003).

\section{Experimental Design}

The trapping study was conducted in 54 plots, with 27 plots selected in the grazed area (hereafter referred as "GA") and 27 plots selected in the not-grazed area (hereafter referred as "NGA"). Location maps of these plots are in Appendix C. The 27 plots were categorized by plant community through a visual estimation of plant cover. Within each GA and NGA, nine plots were comprised of coastal scrub vegetation, nine plots were comprised of grass and forbs vegetation, and nine plots were comprised of a coastal scrub/grass mixture. "Grassland” represented plant assemblages where less than $25 \%$ of the vegetation was shrub, and more than $75 \%$ were grasses and forbs (Appendix B, photos one and two). "Mixed" communities contained roughly 50\% shrub vegetation and $50 \%$ grass and forb vegetation (Appendix B, photos three and four). "Shrubland" communities contained 75\% shrubs and less than 25\% grasses and forbs (Appendix B, photos five and six).

Plot selection consisted of driving or walking around the GA and NGA until suitable habitats were located. Criteria for selecting suitable habitats included 1) vehicle accessibility within a five-minute walking distance from the plot in order to release all animals within three hours after sunrise, 2) did not present a safety concern for trappers, 3) fit the plant community classifications of grass, mixed, or shrub, and 4) were separated from another plot's edge by a distance of at least $80 \mathrm{~m}$. We randomly selected plots for 
the first trapping session by writing each accessible plot designation on a piece of paper, placing them all in a hat, closed our eyes, and chose four plots in the GA and four plots in the NGA. The other plots during the following trap sessions were selected based on seasonal accessibility.

\section{Study Design}

Rodent captures were observed and compared among plant community types (shrub-dominated/grass-dominated/mixed) and management practice (grazed, not grazed). This was a balanced design, with nine replicates of each vegetation type in each of the two management practice areas, for a total of fifty-four observation plots. Plots measured 40 meters by 40 meters in size, spaced at least 80 meters apart. There were a total of 27 plots for each management practice, 18 plots for each plant community, and nine plots for each management/plant community group combination.

\section{Data Collection Process}

One 3 X 3 grid was set up within each 40 X 40 meter plot. A total of nine trapping locations spaced twenty meters apart made up the dimensions of the grid, so that three rows and three columns of nine trapping stations in each plot (Figure 1). Two traps were set up at each trapping station (Appendix B, photo seven), for a total of eighteen traps per plot. Each trapping session was conducted over three continuous trap nights. A trap-night is the number of traps in the plot multiplied by the number of nights trapping occurred (Jones et al., 1996). A minimum of 400-500 trap-nights is recommended by Jones et al. 
(1996) for a preliminary inventory of a habitat. Our methodology totaled 54 trap-nights per plot, and 486 trap-nights per community in the GA and NGA.

\begin{tabular}{|c|c|c|}
\hline $\mathrm{X}$ & $\mathrm{X}$ & $\mathrm{X}$ \\
\hline 00 & 00 & 00 \\
\hline X & $\mathrm{X}$ & $\mathrm{X}$ \\
\hline 00 & 00 & 00 \\
\hline $\mathrm{X}$ & $X$ & $\mathrm{X}$ \\
\hline 00 & oo & 00 \\
\hline \multicolumn{3}{|c|}{ |---- 20 m ----| } \\
\hline
\end{tabular}

Figure 1. Example of $3 \mathrm{X} 3$ grid plot layout. "X" refers to trapping station. "o" refers to Sherman live traps. Total plot area was 40 by 40 meters, with 20 meter spacing between trapping stations.

The small mammals were captured using medium Sherman live traps (Appendix E, photo 16). The Sherman live traps were baited with rolled oats. Cotton balls were added to the traps to reduce hypothermia risk in captured animals. The traps were set approximately three hours prior to sunset and checked within three hours after sunrise. All traps were closed during the daytime. Trapping was conducted during a two-year period from March, 2007 to February 2009. Table 2 contains the dates for corresponding plot collections. 
Following collection, the small mammals were identified to species, marked, and released at their original location (Appendix B, photos nine through sixteen). We marked the rodents by clipping an estimated $1 \mathrm{~cm}$ squared portion of the guard hairs or coloring the top fur layer with a marker in order to recognize recaptures. The recaptures were recorded, but not included in the analysis count numbers.

Table 2. Summary of trapping session dates and plot types.

\begin{tabular}{|cccccccccc|}
\hline & & \multicolumn{3}{c}{ Grazed } & & \multicolumn{3}{c|}{ Not Grazed } \\
\cline { 3 - 5 } Date & & Grass & Mixed & Shrub & & Grass & Mixed & Shrub \\
\hline March, 2007 & Plots & 2 & 1 & 0 & & 0 & 2 & 2 \\
\hline July, 2007 & Plots & 1 & 1 & 1 & & 0 & 0 & 0 \\
\hline October, 2007 & Plots & 1 & 0 & 2 & & 4 & 0 & 0 \\
\hline January, 2008 & Plots & 0 & 2 & 2 & & 2 & 1 \\
\hline June, 2008 & Plots & 0 & 1 & 3 & & 0 & 3 & 1 \\
\hline September, 2008 & Plots & 4 & 0 & 0 & & 1 & 2 \\
\hline December, 2008 & Plots & 0 & 2 & 0 & 2 & 1 & 1 \\
\hline February, 2009 & Plots & 1 & 2 & 1 & 2 & 0 & 2 \\
\hline & Total & 9 & 9 & 9 & 9 & 9 & 9 \\
\hline
\end{tabular}

Our hypotheses would be supported by 1) finding equal amounts of Peromyscus maniculatus, Thomomys bottae, Rattus rattus, and Rattus norvegicus captures in all three habitat types in both the grazed and not-grazed areas; 2) finding more Chaetodipus californicus, Neotoma fuscipes, Neotoma lepida, Peromyscus californicus captures in the shrubland community than the mixed or grassland communities in both the grazed and 
not-grazed areas; 3) finding more Reithrodontomys megalotis and Microtus californicus captures in the grassland community than the mixed or shrubland community in both the grazed and not-grazed areas; and 4) finding more rodent species diversity in the shrubland community than the mixed or grassland community for both the grazed and not-grazed areas though utilizing a species diversity index.

\section{Statistical Approach}

Species diversity index and species counts were analyzed. The differences in species abundance within each plot were compared using a diversity index, specifically the Shannon index. Shannon's diversity index is a heterogeneity measure of diversity that takes into account species evenness as well as species richness (Magurran, 2004). Species evenness refers to the similarity of relative abundance of different species (Wilson et al., 1996). Species richness is the total number of species in a community (Wilson et al., 1996). We measured species counts by a capture index, or the number of individual rodent captures per total number (486) of trapnights (Conroy, 1996). A summary of all data are located in appendix D.

The Shannon's diversity index results were analyzed using a 2-way analysis of variance (ANOVA) analysis in the Minitab 15 software. A Tukey analysis with an error rate of 5\% was conducted on the Shannon's diversity index response variable to examine any significant results. Confidence intervals were used to compare means for various groups. The data were transformed so that the normal errors assumption was not severely violated (Appendix E). The Shannon's diversity index data followed a normal distribution after taking the square-root of the data. Shannon's diversity index had no evidence of 
non-constant variance (Appendix E). Species captures were considered random since trappers did not have control of the small mammals.

All analyses of the count data were done at the species level. The count data were analyzed using a log linear Poisson regression model approach to examine the relationship of each rodent species captures to treatment and plant community (Appendix E). The interaction effects were estimated using Equation 1.

Equation 1. Log linear model calculation.

$$
\begin{aligned}
& \ln (y)=\alpha+\beta_{1} X_{1}+\beta_{2} X_{2}+\beta_{3} X_{3}+\beta_{4} X_{1} X_{2}+\beta_{5} X_{1} X_{3}, \\
& \text { Where, } \\
& \qquad \begin{array}{l}
\mathrm{y}=\text { the species count } \\
X=\text { a dummy variable } \\
X_{1}=1 \text { if plot is not grazed, otherwise } X_{1}=0 . \\
X_{2}=1 \text { if community is mixed, otherwise } X_{2}=0 . \\
X_{3}=1 \text { if community is shrub, otherwise } X_{3}=0 .
\end{array}
\end{aligned}
$$

A post-hoc analysis at the family confidence level of $95 \%$ for Wald chi-square confidence intervals was conducted for pairwise comparisons of the species count marginal means through the Statistical Package for the Social Sciences software Version 21 program (Appendix E). The post hoc Wald confidence intervals incorporated a Bonferroni correction for multiple comparisons. 


\section{CHAPTER 4}

\section{RESULTS}

A total of eight different species were captured. Peromyscus maniculatus (North American deermouse) and Reithrodontomys megalotis (western harvest mouse) were the only two species out of the eight species captured with sufficient observations to support a loglinear model analysis that included interactions for the treatment and community factors. Peromyscus boylii (brush deermouse), Neotoma fuscipes (dusky-footed woodrat), Chaetodipus californicus (California pocket mouse), Microtus californicus (California vole), Neotoma lepida (desert woodrat), and Peromyscus californicus (California deermouse) had insufficient observations to support a log-linear model analysis.

There were not enough data counts for the log linear model to successfully complete an interaction test to estimate interaction effects for the brush deermouse and the dusky-footed woodrat. In addition, there was a high standard error for the community factor in both species. Since the two factors cannot be tested for an interaction effect, the factors cannot be statistically analyzed individually.

Out of all 54 plots, the California pocket mouse was only captured in two plots in the grazed shrubland community, three plots in the not-grazed shrubland community, and two plots in the not-grazed mixed community. The California vole was captured in one plot in the grazed mixed community, in one plot in the grazed shrubland community, in one plot in the not-grazed grassland community, and in two plots in the not-grazed mixed 
community. The desert woodrat was captured in two plots in the grazed shrubland community and in one plot in the not-grazed grassland community. The California deermouse was captured in one plot in the grazed mixed community. Data summaries are located in Appendix D.

\section{Shannon's Diversity Index}

Figures 2 and 3 contain summaries of the observation data. A 2-way ANOVA gave no evidence of an interaction effect $(\mathrm{p}=0.147)$ between plant community type and management practice (Table 3) or of any difference in management practice $(p=0.194$, Table 4), but there was evidence of a community effect $(\mathrm{p}<0.001$, Table 4$)$. The Tukey analysis provided evidence that the species diversity in the grass-dominated community was significantly less than the mixed and shrub-dominated communities (Table 5). When the Shannon's diversity index means were adjusted to follow a normal distribution by taking the square-root of the mean, the species diversity in the grassland community was 0.248 to 0.795 lower than the mixed community and 0.262 to 0.810 lower than the shrub community on average. 


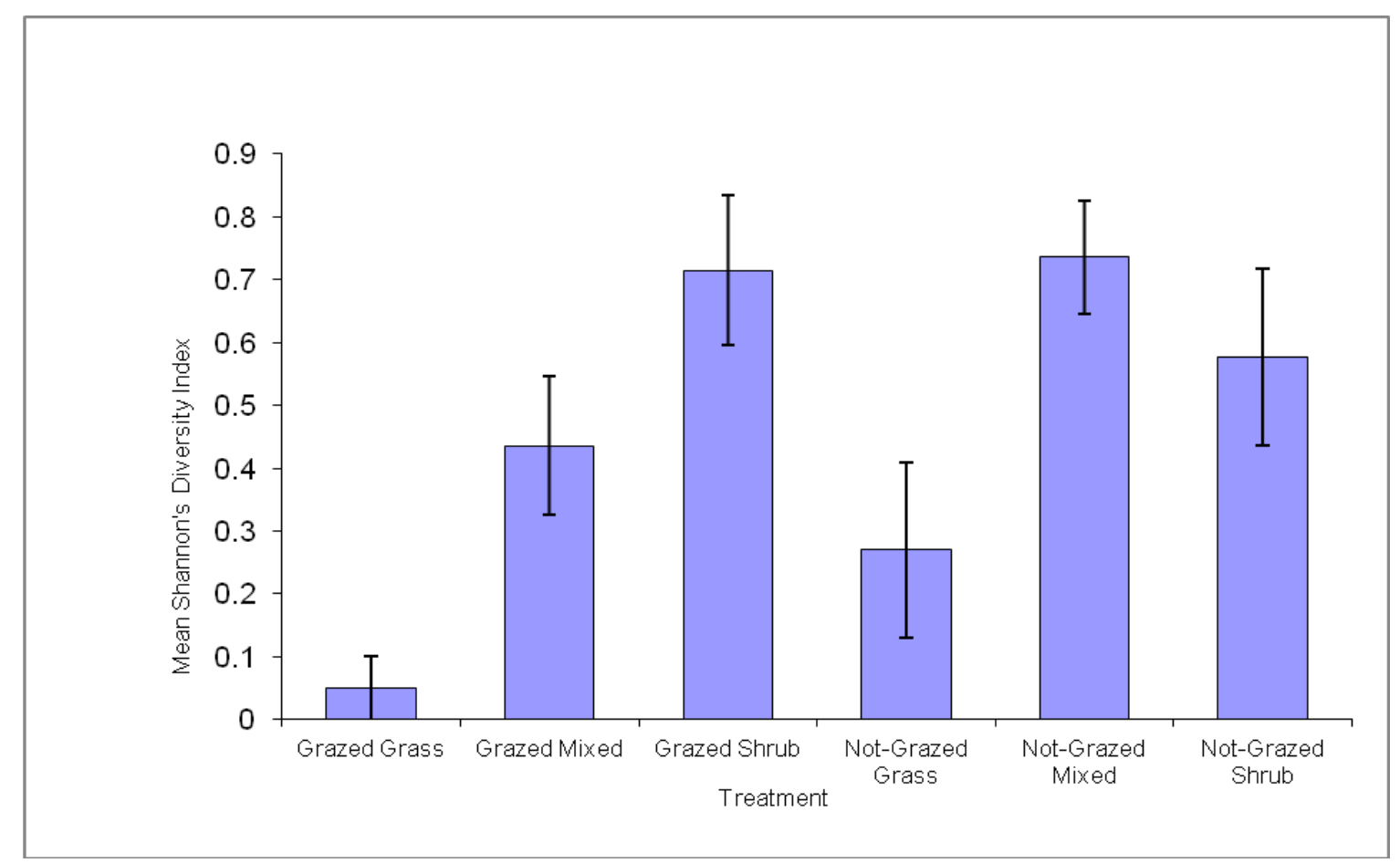

Figure 2. Mean Shannon's diversity index for each management/plant community group. The error bars represent 1 standard error above and below the mean.

Table 3. 2-Way ANOVA results with the interaction effect. A comparison of the observed Shannon's Diversity Index means for each community and management type.

\begin{tabular}{|c|c|c|c|c|c|c|}
\hline & \multicolumn{3}{|c|}{ Community } & \multicolumn{2}{|c|}{ Management } & \multirow{2}{*}{$\frac{\text { Interaction }}{\mathrm{M}^{*} \mathrm{C}}$} \\
\hline & Grass & Mixed & Shrub & Grazed & $\begin{array}{c}\text { Not } \\
\text { Grazed }\end{array}$ & \\
\hline Shannon DI Mean & 1.24 & 1.9 & 2.04 & 1.84 & 1.62 & \\
\hline Adj MS & & 1.679 & & & & 0.221 \\
\hline $\mathrm{F}$ & & 15.12 & & & & 1.99 \\
\hline p-value & & $<0.001$ & & & & 0.147 \\
\hline
\end{tabular}




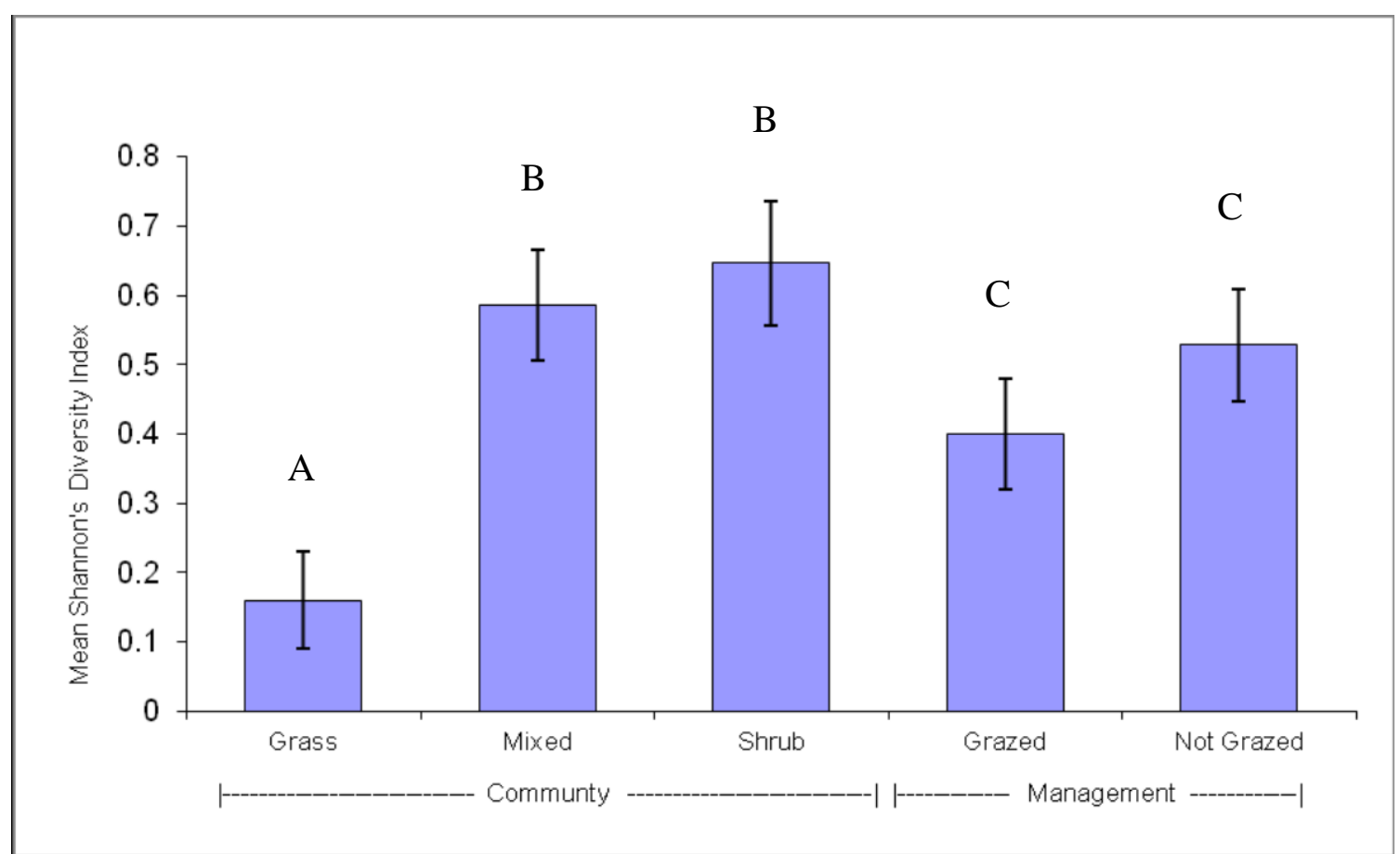

Figure 3. Mean Shannon's diversity index for each community and management type. The error bars represent 1 standard error above and below the mean. Similar letters are not significantly different from each other.

Table 4. 2-Way ANOVA results without the interaction effect. A comparison of the observed Shannon's Diversity Index means for each community and management type.

\begin{tabular}{ccccccc} 
& \multicolumn{3}{c}{ Community } & & \multicolumn{2}{c}{ Management } \\
\cline { 2 - 4 } \cline { 5 - 6 } & Grass & Mixed & Shrub & & Grazed & $\begin{array}{c}\text { Not } \\
\text { Grazed }\end{array}$ \\
\hline Shannon DI Mean & 0.16 & 0.59 & 0.09 & & 0.4 & 0.53 \\
\pm SE & \pm 0.07 & \pm 0.08 & \pm 0.09 & & \pm 0.08 & \pm 0.08 \\
Adj MS & & 1.679 & & & \multicolumn{2}{c}{0.2} \\
F & & 14.54 & & & 1.73 \\
p-value & & $<0.001$ & & & 0.194 \\
\hline
\end{tabular}


Table 5. Tukey comparative analysis of the Shannon's diversity index means. Means of groups are significantly different at the family confidence coefficient of 95\%. The levels are $\mathrm{G}$ for grass, $\mathrm{M}$ for mixed, $\mathrm{S}$ for Shrub. The treatments are $\mathrm{Gr}$ for grazed and NGr for not-grazed. The values represent the confidence intervals of the comparisons. "*" indicates a significantly different comparison.

\begin{tabular}{|cc|}
\hline \multicolumn{2}{|c|}{$(\text { Shannon's Diversity Index })^{\wedge} 0.5$} \\
M-G & $(0.248,0.795)^{*}$ \\
S-G & $(0.262,0.810)^{*}$ \\
S-M & $(-0.259,0.288)$ \\
NGr-Gr & $(-0.064,0.307)$ \\
\hline
\end{tabular}

\section{Count Data: Peromyscus Maniculatus (North American Deermouse)}

Observations of mean count data are in Figure 4. The Wald chi-square test and the log linear Poisson regression model provided evidence of an interaction among the management practice and plant community type variables for North American deermouse with a p-value of $<0.05$ (Tables 6 and 7, Figure 6). On average of 486 trapnights, the North American deermouse was captured the most often in the not-grazed shrubland with between 5.96 to 10.49 more captures than the grazed grassland; between 4.75 to 9.48 more captures than the not-grazed mixed group; between 2.93 to 7.96 more captures than the grazed shrubland; between 1.49 to 6.73 more captures than the not-grazed grassland; and between 0.05 to 5.51 more captures than the grazed mixed group $(p<0.05)$. We observed that on average of 486 trapnights, the grazed grass group had between 1.11 to 4.45 fewer North American deermouse captures than the grazed shrub group; and between 2.28 to 5.95 fewer North American deermouse captures than the not-grazed grass group (Table 8). On average of 486 trapnights, the grazed mixed group had between 
0.4 to 4.93 more North American deermouse captures than the grazed shrub group; and between 2.23 to 6.43 more North American deermouse captures than the not-grazed mixed group (Table 8).

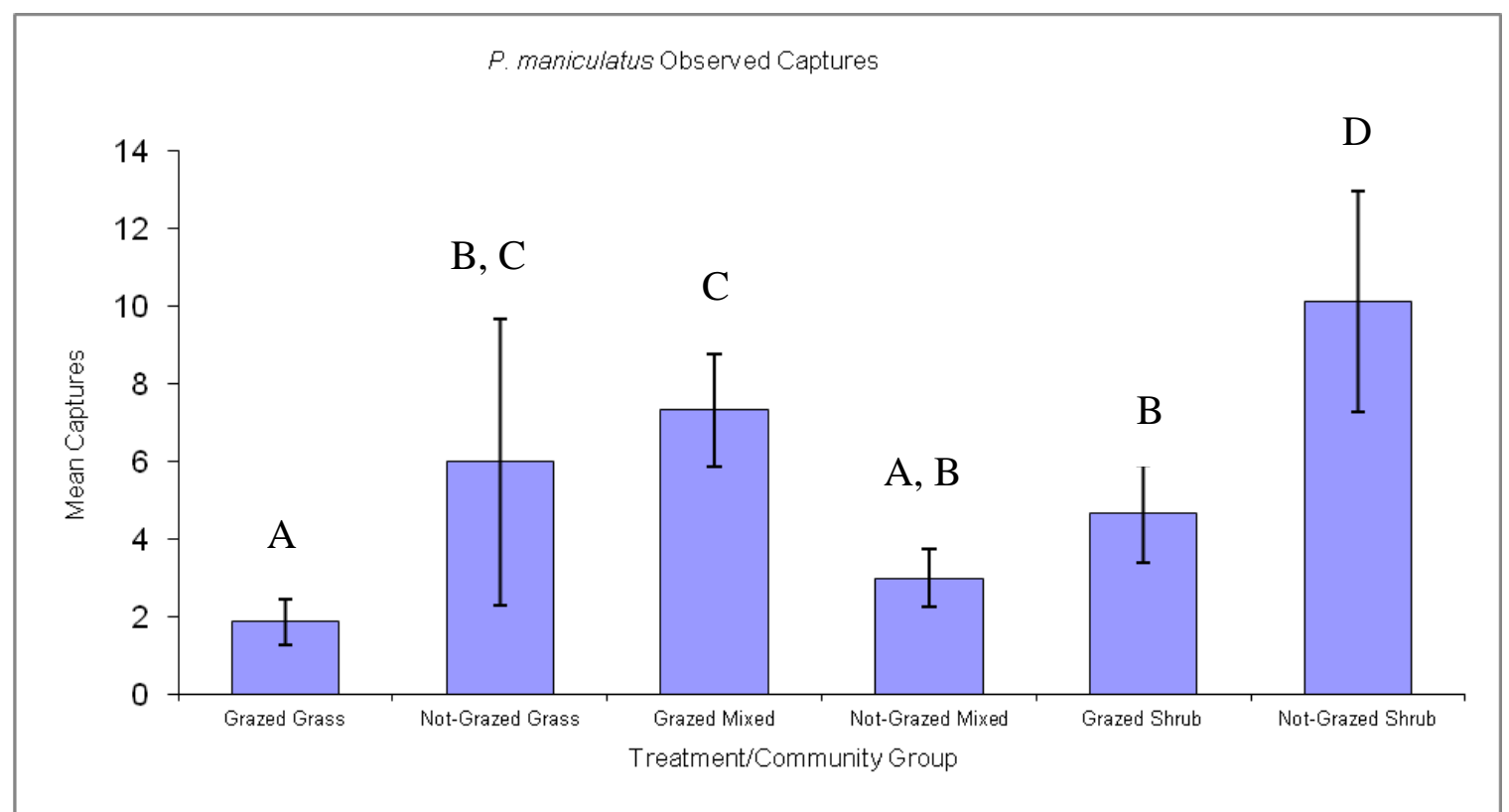

Figure 4. Mean number of observed North American deer mouse counts per 486 trapnights for each management/plant community group. The error bars represent 1 standard error above and below the mean. Similar letters are not significantly different from each other. 
Table 6. Summary of the log linear results for species count data. Reference group is the Grazed Treatment and Grass Community. Estimates of species counts are compared to the reference group. A "***" means there was insufficient plot representation to conduct an interaction test for a log linear model.

\begin{tabular}{|l|c|cccccc|}
\hline \multicolumn{2}{|c|}{} & \multicolumn{3}{c|}{ Treatment } & \multicolumn{4}{c|}{ Community } \\
\hline \multicolumn{2}{|c|}{} & Intercept & Not Grazed & $\begin{array}{c}\text { Grazed } \\
\text { Mixed }\end{array}$ & $\begin{array}{c}\text { Grazed } \\
\text { Shrub }\end{array}$ & $\begin{array}{c}\text { Not } \\
\text { Grazed } \\
\text { Mixed }\end{array}$ & $\begin{array}{c}\text { Not } \\
\text { Grazed } \\
\text { Shrub }\end{array}$ \\
\hline P. man & & & & & & & \\
& Estimate & 2.83 & 1.16 & 1.36 & 0.9 & -2.05 & -0.38 \\
& P-value & $<0.001$ & $<0.001$ & $<0.001$ & 0.002 & $<0.001$ & 0.253 \\
& SE & 0.24 & 0.28 & 0.27 & 0.29 & 0.36 & 0.33 \\
\hline R. mega & Estimate & 0.00 & 3.04 & 2.20 & 2.20 & -2.84 & -3.85 \\
& P-value & 1.000 & 0.003 & 0.037 & 0.037 & 0.011 & 0.002 \\
& SE & 1.00 & 1.024 & 1.05 & 1.05 & 1.12 & 1.19 \\
\hline P. boylii & Estimate & -23.06 & 1.50 & 24.00 & 24.30 & $* * *$ & $* * *$ \\
& P-value & 0.999 & 0.001 & 0.999 & 0.999 & $* * *$ & $* * *$ \\
& SE & 26345.11 & 0.45 & 26345.11 & 26345.11 & $* * *$ & $* * *$ \\
\hline N. fus & Estimate & -19.08 & -0.43 & 20.66 & 21.58 & $* * *$ & $* * *$ \\
& P-value & 0.998 & 0.261 & 0.997 & 0.997 & $* * *$ & $* * *$ \\
& SE & 6580.19 & 0.387 & 6580.19 & 5680.19 & $* * *$ & $* * *$ \\
\hline
\end{tabular}

Table 7. Wald test results. A comparison of the observed species count means for each community and management type with the interaction effect.

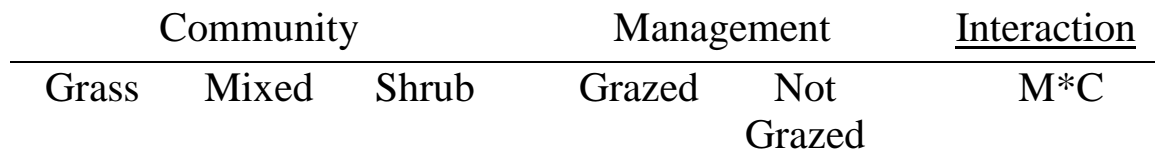

\begin{tabular}{|c|c|c|c|c|c|c|}
\hline \multirow{2}{*}{$\begin{array}{l}\text { P. man Mean } \\
\text { p-value }\end{array}$} & 3.37 & 4.69 & 6.87 & 4.01 & 5.67 & \\
\hline & & 0.000 & & \multicolumn{2}{|c|}{.011} & $<0.001$ \\
\hline R. mega Mean & 0.51 & 1.11 & 0.67 & 0.48 & 1.08 & \\
\hline $\mathrm{p}$-value & & 0.221 & & & & 0.005 \\
\hline
\end{tabular}




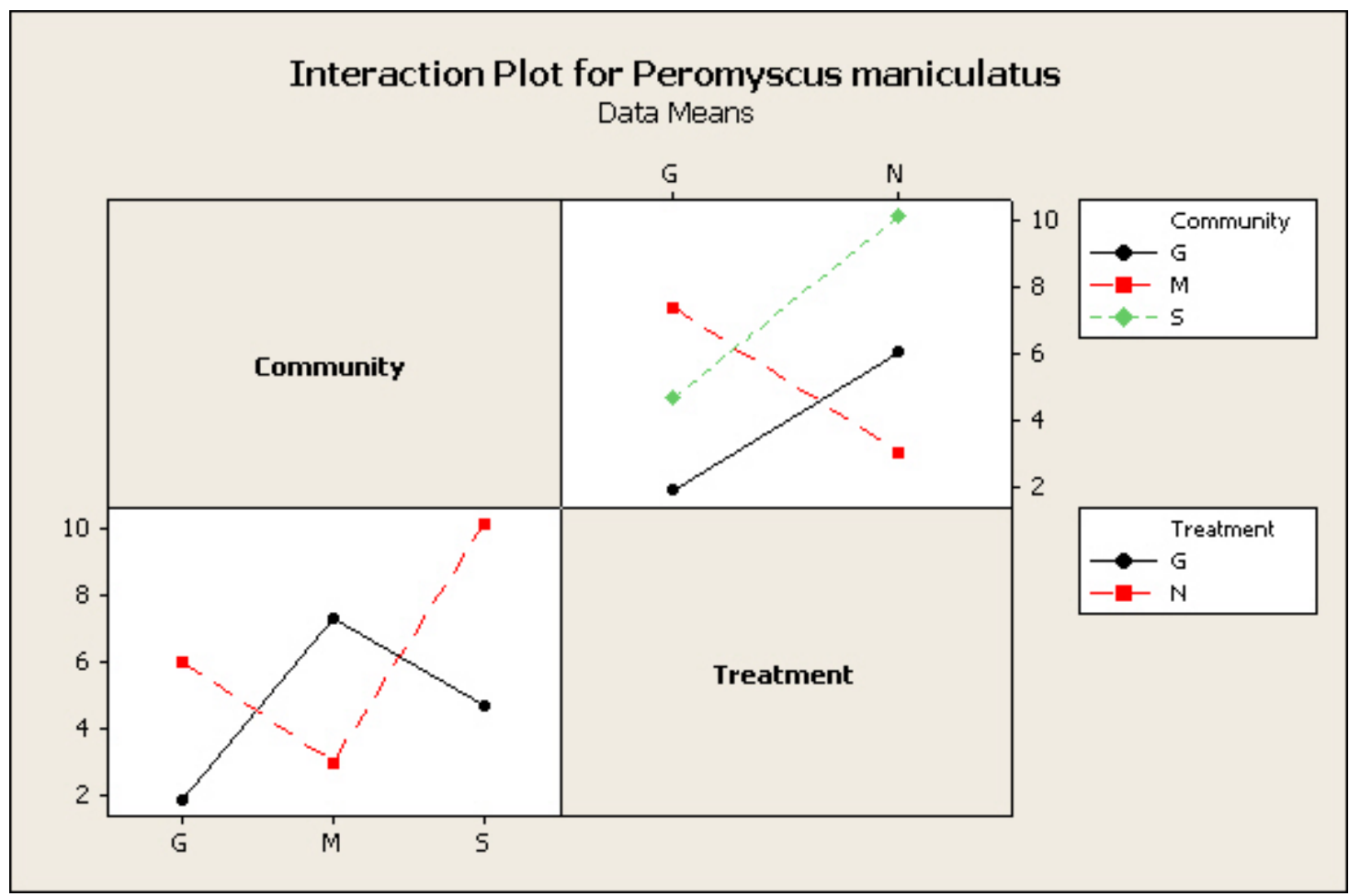

Figure 5. Management practice and plant community interaction plot on the number of captures for the species Peromyscus maniculatus. 
Table 8. Post-hoc comparative analysis of the relationship between the species count interactions per 486 trapnights. The levels are $\mathrm{G}$ for grass, $\mathrm{M}$ for mixed, $\mathrm{S}$ for Shrub. The treatments are Gr for grazed and NGr for not-grazed. The values represent the confidence intervals of the comparisons. * indicates significantly different relationship.

\begin{tabular}{|cc|cl|}
\multicolumn{2}{c|}{ North American deermouse } & \multicolumn{2}{|c|}{ Western harvest mouse } \\
\hline Gr/G-Gr/M & $(-7.43,-3.46)^{*}$ & $\mathrm{Gr} / \mathrm{G}-\mathrm{Gr} / \mathrm{M}$ & $(-1.92,0.14)$ \\
$\mathrm{Gr} / \mathrm{G}-\mathrm{Gr} / \mathrm{S}$ & $(-4.45,-1.11)^{*}$ & $\mathrm{Gr} / \mathrm{G}-\mathrm{Gr} / \mathrm{S}$ & $(-1.92,0.14)$ \\
$\mathrm{Gr} / \mathrm{G}-\mathrm{NGr} / \mathrm{G}$ & $(-5.95,-2.28)^{*}$ & $\mathrm{Gr} / \mathrm{G}-\mathrm{NGr} / \mathrm{G}$ & $(-3.75,-0.69)^{*}$ \\
$\mathrm{Gr} / \mathrm{G}-\mathrm{NGr} / \mathrm{M}$ & $(-2.56,0.33)$ & $\mathrm{Gr} / \mathrm{G}-\mathrm{NGr} / \mathrm{M}$ & $(-2.24,0.02)$ \\
$\mathrm{Gr} / \mathrm{G}-\mathrm{NGr} / \mathrm{S}$ & $(-10.49,-5.96)^{*}$ & $\mathrm{Gr} / \mathrm{G}-\mathrm{NGr} / \mathrm{S}$ & $(-1.06,0.40)$ \\
$\mathrm{Gr} / \mathrm{M}-\mathrm{Gr} / \mathrm{S}$ & $(0.4,4.93)^{*}$ & $\mathrm{Gr} / \mathrm{M}-\mathrm{Gr} / \mathrm{S}$ & $(-1.38,1.38)$ \\
$\mathrm{Gr} / \mathrm{M}-\mathrm{NGr} / \mathrm{G}$ & $(-1.05,3.72)$ & $\mathrm{Gr} / \mathrm{M}-\mathrm{NGr} / \mathrm{G}$ & $(-3.12,0.45)$ \\
$\mathrm{Gr} / \mathrm{M}-\mathrm{NGr} / \mathrm{M}$ & $(2.23,6.43)^{*}$ & $\mathrm{Gr} / \mathrm{M}-\mathrm{NGr} / \mathrm{M}$ & $(-1.68,1.24)$ \\
$\mathrm{Gr} / \mathrm{M}-\mathrm{NGr} / \mathrm{S}$ & $(-5.51,-0.05)^{*}$ & $\mathrm{Gr} / \mathrm{M}-\mathrm{NGr} / \mathrm{S}$ & $(-0.62,1.73)$ \\
$\mathrm{Gr} / \mathrm{S}-\mathrm{NGr} / \mathrm{G}$ & $(-3.47,0.80)$ & $\mathrm{Gr} / \mathrm{S}-\mathrm{NGr} / \mathrm{G}$ & $(-3.12,0.45)$ \\
$\mathrm{Gr} / \mathrm{S}-\mathrm{NGr} / \mathrm{M}$ & $(-0.14,3.48)$ & $\mathrm{Gr} / \mathrm{S}-\mathrm{NGr} / \mathrm{M}$ & $(-1.68,1.24)$ \\
$\mathrm{Gr} / \mathrm{S}-\mathrm{NGr} / \mathrm{S}$ & $(-7.96,-2.93)^{*}$ & $\mathrm{Gr} / \mathrm{S}-\mathrm{NGr} / \mathrm{S}$ & $(-0.62,1.73)$ \\
NGr/G-NGr/M & $(-3.72,1.05)$ & $\mathrm{NGr} / \mathrm{G}-\mathrm{NGr} / \mathrm{M}$ & $(-0.73,2.96)$ \\
NGr/G-NGr/S & $(-6.73,-1.49)^{*}$ & $\mathrm{NGr} / \mathrm{G}-\mathrm{NGr} / \mathrm{S}$ & $(0.26,3.52)^{*}$ \\
NGr/M-NGr/S & $(-9.48,-4.75)^{*}$ & $\mathrm{NGr} / \mathrm{M}-\mathrm{NGr} / \mathrm{S}$ & $(-0.49,2.04)$ \\
& & & \\
\hline
\end{tabular}




\section{Count Data: Reithrodontomys Megalotis (Western Harvest Mouse)}

Observations of mean count data are in Figure 6. The Wald chi-square test and the log linear Poisson regression model provided evidence of an interaction effect among the grazing status and community factors for $R$. megalotis with a p-value of $<0.05$ (Tables 6 and 7, and Figure 7). On average, the not-grazed grass group had between 0.69 to 3.75 more $R$. megalotis captures than the grazed grass group per 486 trapnights (Table 11). The not-grazed grass group had 0.26 to 3.52 more captures per 486 trapnights than the not-grazed shrub group on average (Table 11).

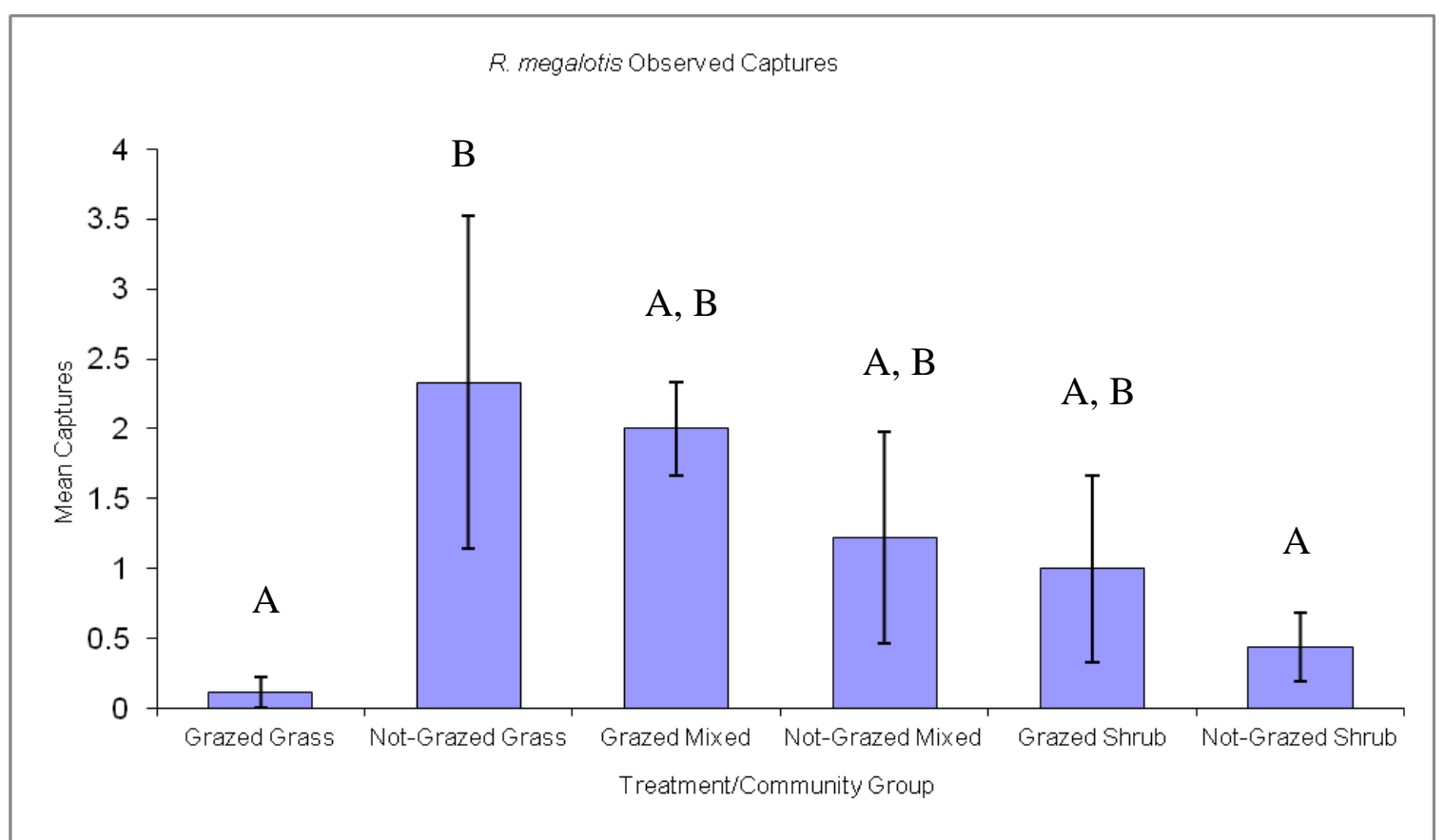

Figure 6. Mean number of observed western harvest mouse counts per 486 trapnights for each management/plant community group. The error bars represent 1 standard error above and below the mean. Similar letters are not significantly different from each other. 
Figure 7. Management practice and plant community interaction plot on the number of captures for the species Reithrodontomys megalotis.

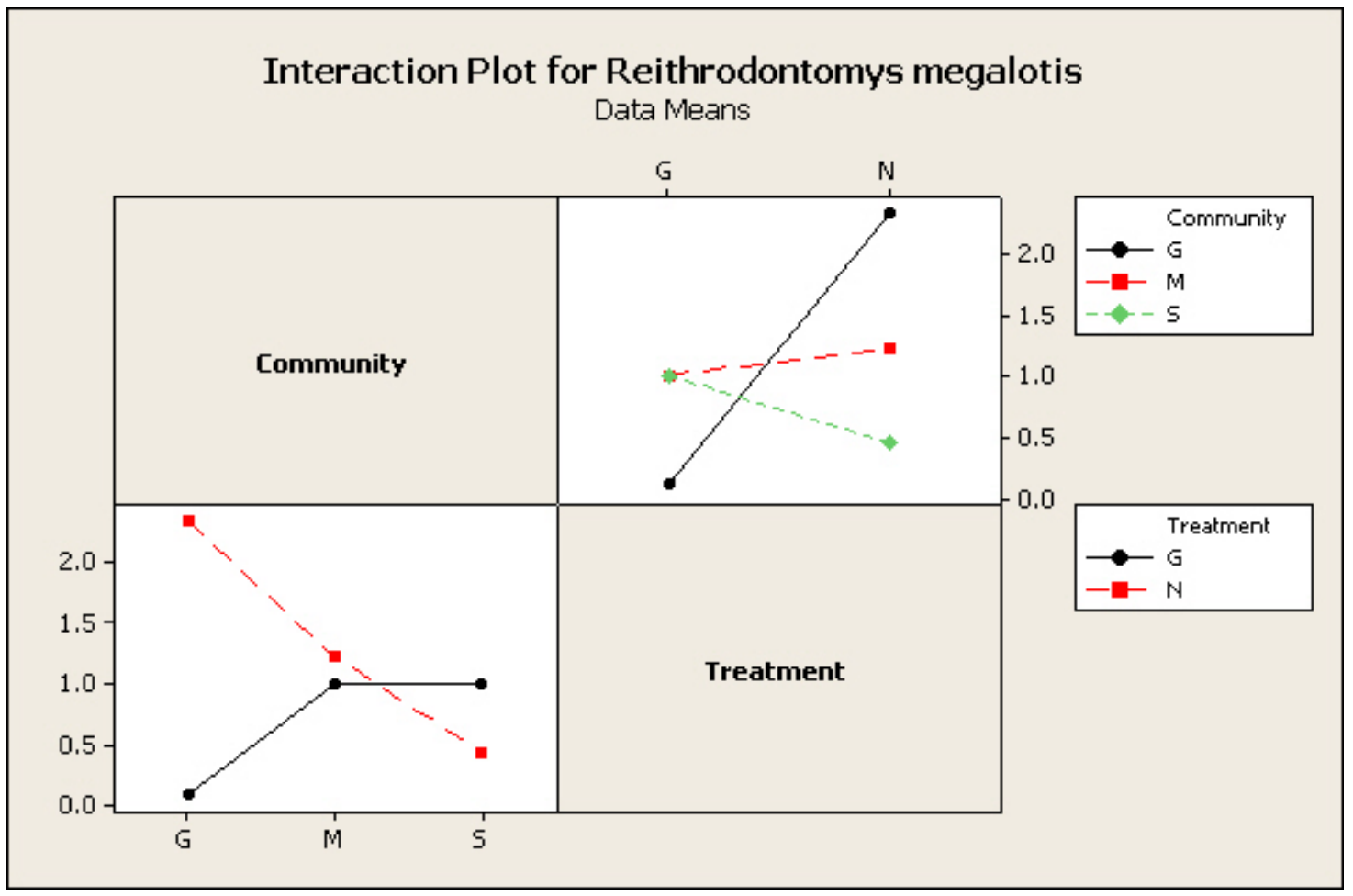




\section{CHAPTER 5}

\section{DISCUSSION AND CONCLUSION}

Based on the field guide created by Kays and Wilson (2002), we expected to find ten rodent species in the habitats within the study area. However, we only captured eight rodents, but could not analyze six species due to low species counts. The hypotheses under investigation were:

1) Peromyscus maniculatus, Thomomys bottae, Rattus rattus, and Rattus norvegicus are commonly found in all habitat types; therefore, we expect to find them equally in all three plant community types and in both the grazed and not-grazed areas.

2) We expect to find Chaetodipus californicus, Neotoma fuscipes, Neotoma lepida, Peromyscus californicus more often in the shrubland community since they are known to occur in coastal scrub habitat, but equally present in both the grazed and not-grazed areas.

3) We expect to find Reithrodontomys megalotis and Microtus californicus more often in the grassland community since they are commonly found in grassland habitat, but equally present in both the grazed and not-grazed areas.

4) We expect to find greater rodent species diversity in the shrubland community, but equal diversity in both the grazed and not-grazed areas, since there are two 
more rodent species in the study area that prefer shrubland habitat to grassland habitat.

We failed to support or contradict our first, second, and third hypotheses since we could not analyze the following species: Botta’s pocket gopher, House rat, Brown rat, California pocket mouse, Dusky-footed woodrat, Desert woodrat, California deermouse, and California vole. Since we were able to analyze the North American deermouse and the western harvest mouse, we created a sub-hypothesis for each of these species. Subhypothesis 1-1: We expected to find Peromyscus maniculatus (North American deermouse) equally in all three plant community types and equally in both management practices. Sub-hypothesis 2-1: We expected to find Reithrodontomys megalotis (western harvest mouse) more often in the grassland community but equally in both management practices.

We did find some evidence that impacts of rotational grazing on the North American deermouse and the western harvest mouse counts depended upon plant community $(\mathrm{p}<0.05)$. However, we were not expecting these results.

\section{Peromyscus Maniculatus (North American Deermouse)}

The deer mouse is a habitat generalist, known to tolerate many habitats and consume a generalized diet. They are found in open areas, brushlands, coniferous and deciduous forests, grasslands, woodlands, and marine shorelines (Kays and Wilson, 2002; M’Closkey, 1972; Meserve, 1976b; Province of British Columbia, 1998). The deer mouse primarily eats seeds (Province of British Columbia, 1998); but also consumes fruits, leaves, arthropods, fungi, birds and other mice Jameson, 1952. Since deer mice are 
commonly found in all habitat types, we hypothesized that the deer mice would be equally observed in all three plant community types in both management practices. However, we observed the deer mice abundance mainly in the shrubland community in the not-grazed area $(\mathrm{p}<0.05)$, with between 5.96 to 10.49 more captures than the grazed grassland, between 4.75 to 9.48 more captures than the not-grazed mixed group, between 2.93 to 7.96 more captures than the grazed shrubland, between 1.49 to 6.73 more captures than the not-grazed grassland, and between 0.05 to 5.51 more captures than the grazed mixed group on average of 486 trapnights. The deer mice abundance varied among the other treatment and plant community combinations $(\mathrm{p}<0.05)$. Our sub-hypothesis $1-1$ was rejected because North American deermouse abundance were not equally distributed among the three plant communities in either management practice.

\section{Reithrodontomys Megalotis (Western Harvest Mouse)}

The western harvest mouse is primarily a grassland species, utilizing habitats dominated by dense herbaceous vegetation including prairies, meadows, overgrown pastures, agricultural areas, stream valleys, and estuarine marshes (Kays and Wilson, 2002; Province of British Columbia, 1998). The western harvest mouse prefers a forb and grass seed diet, but also eats some herbaceous material (Province of British Columbia, 1998; Meserve, 1976a). Since western harvest mice are commonly found in grasslands, we hypothesized that they would be found more often in the grassland habitats in both management practices. However, we observed that western harvest mouse abundance varied among the treatment and plant community combinations ( $\mathrm{p}<0.05)$, but no single combination dominated all other combinations in captures. We observed that on average 
of 486 trapnights, the not-grazed grass group had between 0.69 to 3.75 more western harvest mouse captures than the grazed grass group and between 0.26 to 3.52 more captures per 486 trapnights than the not-grazed shrub group. Since the grassland habitat did not have more western harvest mice abundance than the other communities in both management types, we rejected our hypothesis.

\section{Biological Diversity}

We found no evidence that the rotational grazing practices used at Pecho Ranch had much influence on Shannon's diversity index (p>0.05). Bich et al. (1995), Chapman and Ribic (2002), and Schmidt et al. (2005) also did not observe any differences in rodent species diversity among grazed and not-grazed areas. Bock et al. (1984) and Grant et al. (1982) both observed more species diversity in grazed areas than in not-grazed areas. Bock et al. (2006) and Rosenstock (1996) observed more species diversity in non-grazed areas than grazed areas. Our results indicated that plant community does affect the Shannon's diversity index at Pecho Ranch and Montana de Oro State Park. In this case, the grass-dominated plant community had less rodent diversity than the grass-shrub mixed community and the shrub-dominated community.

Since we hypothesized that we were expecting to find greater rodent species diversity in the shrubland habitat in both management practices, but found that the mixed communities and the shrub communities did not differ in species diversity ( $>>0.05)$, we reject this hypothesis. Structural diversity of a habitat may be influenced by vegetation structure (Ricklefs, 2001); however, since we did not quantify vegetation species in our study, we do not know if the structural diversity differed among our three plant 
communities. Our results provided evidence that rodent species diversity responds to habitat conditions in Montana de Oro State Park and Pecho Ranch.

\section{Vegetation}

While we do not know the reasons behind our observations, we highly suspect that the key lies in the plant litter. Plant litter amounts may be associated with the differences in rodent species captures. Kaufman et al. (1989) observed that North American deer mice were more prevalent in areas with low plant litter and western harvest mouse were more abundant in areas of high plant litter. The North American deer mouse also forages in areas of low plant litter and the western harvest mouse forages in areas with moderate levels of plant litter (Clark and Kaufman, 1991). Unfortunately, plant litter information was not included in our study, so we do not know if there was a relationship between plant litter and rodent captures among the plant communities in our study. Hayes and Holl (2003) have observed that grazed grassland in a California coastal environment had between 3.33 to 4.23 times less plant litter and 1.67 to 2.0 times lower vegetation height than non-grazed grasslands. To determine if plant litter depth was connected with the rodent results, a repeat trapping study would need to be conducted that included measuring the plant litter depth and the plant height.

\section{Climate}

Rainfall totals and distribution between seasons could have impacted the availability of resources within these plant communities. During our two years of study, there were two consecutive seasons of drought (Western Regional Climate Center, no 
date). Holechek et al. (2004) describes a drought as the timeframe during which the average annual precipitation is less than $75 \%$ of average. During the $2006-2007$ wateryear, less than $45 \%$ of the average precipitation occurred. During the $2007-2008$ wateryear, the study area received only $68 \%$ of the average precipitation, with $61 \%$ of the seasonal rainfall occurring in January. Above average monthly rainfall only occurred during two months of the entire study: January 2008 and February 2009. The rest of the months had below average precipitation. Six trapping sessions occurred during the two consecutive drought years and two trapping sessions occurred during the months of above average rainfall. Fraschina et al. (2012) observed that precipitation positively affected rodent populations in subsequent seasons, but negatively affected rodent abundance during the season when rainfall occurred. However, our observations appear different than theirs in that we observed the highest captures in five out of six groups during February 2009 (the first above average rainfall month in over a year), including the grazed grassland, the grazed shrubland, the grazed mixed, the not-grazed grassland, and the not-grazed shrubland. The fewest captures in all groups occurred during the drought years, but not during a specific month. According to Holecheck et al. (2004), drought can reduce forage production by more than $50 \%$ compared to the annual average. Since multiple studies have documented that rodent population sizes (Jones et al., 2003; Kaufman et al., 1989; Powers et al., 2011) and rodent foraging preferences (Clark and Kaufman, 1991) are influenced by vegetation, we speculate that if the vegetation was affected by the drought, the rodent captures may also have been affected. 


\section{Study Improvements}

Since multiple studies have documented that rodent population sizes (Kaufman et al., 1989; Jones et al., 2003; Powers et al., 2011) and rodent foraging preferences (Clark and Kaufman, 1991) are influenced by vegetation, we think it would be useful to add litter depth, vegetative cover, and plant species composition metrics to further studies along these lines.

We recommend trapping when livestock are not present in the grazed area. Our trappers observed livestock springing traps after they had finished setting the traps and were walking away from the plot. Traps were also found several feet away from the initial location during processing. This disturbance likely reduced the amount of available traps for the rodents. While the presence of cattle may not reduce rodent activity (Bueno et al., 2012), studies involving rotational grazing trapped rodents when livestock were not present in the study area, but immediately before and after the onset of grazing (Johnson and Horn, 2008; Chapman and Ribic, 2002). Due to the disturbed traps in our study and following the example of other rotational grazing studies, we recommend trapping immediately before and immediately after the onset of grazing.

We would also set the trap stations closer together. Jones et al. (1996) recommends placing traps every 10 to 15 meters as a starting point. Since we placed our traps 20 meters apart, there were less available traps for the rodents. Fewer traps means there are less available trapnight opportunities to capture rodents.

Checking traps was faster when we had a recorder to write down the captures while we processed our rodents. However, it is very important to remind them upon 
arriving at each plot to differentiate capture information by plots. We had data sets that I could not use simply because the plots were not separated on the datasheets.

Choosing all plot locations and then organizing them into a randomized block design prior to trapping would be ideal to reduce bias in plot selection. Blocking the plots prior to trapping would ensure that all plots are equally represented during each trapping session. In addition we would trap in six plots at every trapping event, where three plots would be on the grazed area representing each plant community and three plots in the not-grazed area representing each plant community.

\section{Conclusions}

To answer our original research question, we did not find evidence that livestock rotational grazing affected species diversity through comparison with the not-grazed area ( $>$ 0.05). However, we found evidence that livestock rotational grazing does affect the North American deermouse and the western harvest mouse abundances differently among the three plant communities.

We found evidence that rodent biological diversity is less in a grassland habitat than in a shrubland habitat or in a grassland/shrubland mixed habitat $(\mathrm{p}<0.001)$. This suggests that the rodents we captured responded to the plant characteristics associated with the presence or absence of grazing. When utilizing rotational livestock grazing to manage for biological diversity, our data indicates that the current livestock grazing system is not causing harm to the rodent biodiversity $(\mathrm{p}>0.05)$. Therefore, no livestock grazing management adjustments are needed.

We found evidence that the North American deermouse abundance responded 
differently to the presence of rotational livestock grazing among the three plant communities. We observed that the North American deermouse was most common in the not-grazed shrub habitat $(\mathrm{p}<0.05)$. The North American deermouse preferred the notgrazed grassland to the grazed grassland, and the not-grazed shrub habitat to the grazed shrub habitat. There was also a higher North American deermouse abundance in the grazed mixed community than the not-grazed mixed community. From a management perspective, the North American deermouse abundance would benefit from not-grazing in a grassland community or a shrubland community and from rotationally grazing in a mixed grassland/shrubland community.

We observed that the western harvest mouse abundance responded differently to the presence of rotational livestock grazing among the grassland community. The western harvest mouse abundance was more prevalent in the not-grazed grassland than in the grazed grassland. From a management perspective, the western harvest mouse abundance would benefit from not-grazing in a grassland community, but appears unaffected by grazing in the shrubland and mixed communities.

\section{Recommendations}

We were unable to identify any clear mechanism of causation for our results. There is the possibility that rodents may be responding to vegetation characteristics other than visual shrubland and grassland cover. Based on previous studies, we think it would be useful to add litter depth, vegetative cover, and plant species composition metrics to future studies along these lines. If a connection is found among the vegetation characteristics and rodent species, then vegetation can be managed by adjusting the 
grazing management practices in order to influence the rodent populations. For example, the North American deer mouse is known to be more prevalent in areas with low plant litter (Kaufman et al., 1989). If we found a similar connection to Kaufman et al. (1989) and adjusted our grazing management to obtain the desired plant litter level, we may improve the abundance of the North American deer mouse. It is important to find the connection between rodents and vegetation prior to manipulating management practices since management programs should be developed from scientific data and principles that result from research on habitat selection (Garton et al., 2005). Monitoring should follow any management changes to confirm that the desired result is being obtained. By further studying the connection(s) between rodent and plant characteristics, we will have more knowledge to create a better livestock management program for the rodents. 


\section{References}

Batzli, G. O., \& Pitelka, F. A. (1971). Condition and diet of cycling populations of the California vole, Microtus californicus. Journal of Mammalogy, 141-163.

Bedell T. (Ed.) (2005). Glossary of terms used in range management (4th ed.). Society for Range Management.

Bich, B. S., Butler, J. L., \& Schmidt, C. A. (1995). Effects of differential livestock use on key plant species and rodent populations within selected Oryzopsis hymenoides/Hilaria jamesii communities of Glen Canyon National Recreation Area. The Southwestern Naturalist, 281-287.

Bock, C. E., Bock, J. H., Kenney, W. R., \& Hawthorne, V. M. (1984). Responses of birds, rodents, and vegetation to livestock exclosure in a semidesert grassland site. Journal of Range Management, 239-242.

Bock, C. E., Jones, Z. F., \& Bock, J. H. (2006). Rodent communities in an exurbanizing southwestern landscape (USA). Conservation Biology, 20(4), 1242-1250.

Bock, C. E., Saab, V. A., Rich, T. D., \& Dobkin, D. S. (1993). Effects of livestock grazing on neotropical migratory landbirds in western North America.

Bradley, J. E., \& Marzluff, J. M. (2003). Rodents as nest predators: influences on predatory behavior and consequences to nesting birds. The Auk, 120(4), 11801187.

Bueno, C., Ruckstuhl, K. E., Arrigo, N., Aivaz, A. N., \& Neuhaus, P. (2012). Impacts of cattle grazing on small-rodent communities: an experimental case study. Canadian Journal of Zoology, 90(1), 22-30.

Chapman, E. W., \& Ribic, C. A. (2002). The impact of buffer strips and stream-side grazing on small mammals in southwestern Wisconsin. Agriculture, ecosystems \& environment, 88(1), 49-59.

Clark, B. K., \& Kaufman, D. W. (1991). Effects of plant litter on foraging and nesting behavior of prairie rodents. Journal of mammalogy, 72(3), 502-512. 
Conroy, M. J. (1996). Abundance indices. In: D. E. Wilson, F. R. Cole, J. D. Nichols, R. Rudran, \& M. S. Foster (Eds). Measuring and monitoring biological diversity: Standard methods for mammals (pp. 179-192). Smithsonian Institution Press, Washington D.C

Davidson, A. D., Lightfoot, D. C., \& McIntyre, J. L. (2008). Engineering rodents create key habitat for lizards. Journal of arid environments, 72(12), 2142-2149.

Filippi, E., Rugiero, L., Capula, M., Capizzi, D., \& Luiselli, L. (2005). Comparative food habits and body size of five populations of Elaphe quatuorlineata: the effects of habitat variation, and the consequences of intersexual body size dimorphism on diet divergence. Journal Information, 2005(3).

Fitch, H. S., \& Twining, H. (1946). Feeding habits of the Pacific rattlesnake. Copeia, 6471.

Fraschina, J., León, V. A., \& Busch, M. (2012). Long-term variations in rodent abundance in a rural landscape of the Pampas, Argentina. Ecological research, 27(1), 191-202.

Fry, M. E. (1992). TES Diablo Canyon land stewardship program Pecho Ranch grazing capacity report. Retrieved March 4, 2014, from http://pbadupws.nrc.gov/docs/ML1116/ML11166A121.pdf

Garton, E. O., Ratti, J. T., \& Giudice, J. H. (2005). Research and Experimental Design (Chapter 8). In C. E. Braun (Ed). Techniques for Wildlife Investigations and Management (pp. 43-71). Port City Press: Baltimore, MD.

Gates, D.L., Bailey, J.H. 1982. Morro Bay’s Yesterdays. San Luis Obispo, CA: Central Coast Press. 149 p.

George, M., Clawson, J., Menke, J., \& Bartolome, J. (1985). Annual grassland forage productivity. Rangelands, 7(1), 17-19.

Grant, W. E., Birney, E. C., French, N. R., \& Swift, D. M. (1982). Structure and productivity of grassland small mammal communities related to grazing-induced changes in vegetative cover. Journal of Mammalogy, 248-260.

Hayes, G. F., \& Holl, K. D. (2003). Cattle grazing impacts on annual forbs and vegetation composition of mesic grasslands in California. Conservation Biology, 17(6), 1694-1702.

Heske, E. J., Brown, J. H., \& Guo, Q. (1993). Effects of kangaroo rat exclusion on vegetation structure and plant species diversity in the Chihuahuan Desert. Oecologia, 95(4), 520-524. 
Holechek, J. L., de Souza Gomes, H., Molinar, F., \& Galt, D. (1998). Grazing intensity: critique and approach. Rangelands, 15-18.

Holechek, J. L., \& Galt, D. (2000). Grazing intensity guidelines. Rangelands, 11-14.

Holechek, J.L., Pieper, R.D., Herbel, C.H. (2004). Range management Principles and Practices (5th ed.). Upper Saddle River, NJ: Pearson Education, Inc.

Huntsinger, L., \& Starrs, P. F. (2006). Grazing in arid North America: A biogeographical approach. Science et changements planétaires/Sécheresse, 17(1), 219-233.

Jameson, E. W. (1952). Food of deer mice, Peromyscus maniculatus and P. boylei, in the northern Sierra Nevada, California. Journal of Mammalogy, 50-60.

Jesperson, C. N. (1939). History of San Luis Obispo County State of California its People and its Resources. Los Angeles: H. M. Meier.

Johnson, M. D., \& Horn, C. M. (2008). Effects of rotational grazing on rodents and raptors in a coastal grassland. Western North American Naturalist, 68(4), 444452.

Jones, C., Mcshea, W. J., Conroy, M. J., \& Kunz, T. H. (1996). Capturing mammals. In: D. E. Wilson, F. R. Cole, J. D. Nichols, R. Rudran, \& M. S. Foster (Eds). Measuring and monitoring biological diversity: Standard methods for mammals (pp. 115-155). Smithsonian Institution Press, Washington D.C.

Jones, Z. F., Bock, C. E., \& Bock, J. H. (2003). Rodent communities in a grazed and ungrazed Arizona grassland, and a model of habitat relationships among rodents in southwestern grass/shrublands. The American midland naturalist, 149(2), 384394.

Kaufman, D. W., Kaufman, G. A., \& Finck, E. J. (1989). Rodents and Shrews in UnGrazed Tallgrass Prairie Manipulated by Fire.

Kays, R. \&Wilson, D.E. (2002). Mammals of North America. Princeton, New Jersey: Princeton University Press.

Kothmann, M. (2009). Grazing methods: a viewpoint. Rangelands, 31(5), 5-10.

Kuminoff, N. V., Sokolow, A.D., Summer, D.A. (2001, May). Farmland conservation: perceptions and realities, appendix A. Agricultural issues center issues brief, 16. Retrieved March 14, 2014, from http://aic.ucdavis.edu/publications/pub/briefs/brief16a.pdf 
Lanszki, J., \& Heltai, M. (2002). Feeding habits of golden jackal and red fox in southwestern Hungary during winter and spring. Mammalian Biology-Zeitschrift für Säugetierkunde, 67(3), 129-136.

Longland, W. S., Jenkins, S. H., Vander Wall, S. B., Veech, J. A., \& Pyare, S. (2001). Seedling recruitment in Oryzopsis hymenoides: are desert granivores mutualists or predators?. Ecology, 82(11), 3131-3148.

Loredo, I., Van Vuren, D., \& Morrison, M. L. (1996). Habitat use and migration behavior of the California tiger salamander. Journal of Herpetology, 282-285.

M'Closkey, R.T. 1972. Temporal Changes in Populations and Species Diversity in a California Rodent Community. Journal of Mammalogy, 53(4): 657-676.

Macon, D., \& Dagget, F. B. D. (2000). Grazing for change. Retrieved March 4, 2014 from http://ucanr.org/sites/sccNew/files/51814.pdf

Magurran, A. E. (2004). Measuring biological diversity. Malden, MA: Blackwell Publishing.

Meserve, P. L. (1976a). Food relationships of a rodent fauna in a California coastal sage scrub community. Journal of Mammalogy, 300-319.

Meserve, P. L. (1976b). Habitat and resource utilization by rodents of a California coastal sage scrub community. The Journal of Animal Ecology, 647-666.

Morrison, A. L., \& Haydon, J. H. (1917). History of San Luis Obispo County and Environs. Los Angeles: Historic Record Company. 1038p.

Neale, J. C., \& Sacks, B. N. (2001). Food habits and space use of gray foxes in relation to sympatric coyotes and bobcats. Canadian Journal of Zoology, 79(10), 1794-1800.

Owen, J. G. (1988). On productivity as a predictor of rodent and carnivore diversity. Ecology, 69(4), 1161-1165.

Pacific Gas and Electric Company. (2006). License agreement for grazing purposes. Retrieved March 4, 2014 from http://www.pge.com/nots/rates/tariffs/tm2/pdf/ELEC_2945-E.pdf

Powers, B., Johnson, M. D., LaManna, J. A., \& Rich, A. (2011). The influence of cattle grazing on pocket gophers in the central Sierra Nevada Mountains, California: potential implications for great gray owls. Northwestern Naturalist, 92(1), 13-18.

Preston, C. R. (1990). Distribution of raptor foraging in relation to prey biomass and habitat structure. Condor, 107-112. 
Province of British Columbia. 1998. Inventory methods for small mammals: shrews, voles, mice and rats. Standards for Components of British Columbia's Biodiversity, No. 31. Resources Inventory Committee. http://www.for.gov.bc.ca/ric/pubs/TEBIODIV/smallmammals/

Ricklefs, R. E. (2001). The Economy of Nature (5th ed.). New York: W. H. Freeman and Company.

Rosenstock, S. S. (1996). Shrub-grassland small mammal and vegetation responses to rest from grazing. Journal of Range Management, 199-203.

Sabadell, J. E., Risley, E. M., Jorgenson, H. T., \& Thornton, B. S. (1982). Desertification in the United States, Status and Issues. Final Report April 1982. 277 p, 34 Fig, 399 Ref, 15 Append.

Sauvajot, R. M., Buechner, M., Kamradt, D. A., \& Schonewald, C. M. (1998). Patterns of human disturbance and response by small mammals and birds in chaparral near urban development. Urban Ecosystems, 2(4), 279-297.

Savory, A., \& Parsons, S. D. (1980). The Savory grazing method. Rangelands Archives, 2(6), 234-237.

Schmidt, N. M., Olsen, H., Bildsoe, M., Sluydts, V., \& Leirs, H. (2005). Effects of grazing intensity on small mammal population ecology in wet meadows. Basic and Applied Ecology, 6(1), 57-66.

Smith, B., Sheley, R., Svejcar, T. ( 2012). Grazing invasive annual grasses: the green and brown guide (United States Department of Agriculture). Oregon State University, Eastern Oregon Agricultural Research Center.

Soreng, R.J., Keil, D.J. 2003. Sequentially adjusted sex-ratios in gynomonoecism, and Poa diaboli (Poaceae), a new species from California. Madroño, Vol. 50, No. 4, pp. 300-306.

Sullivan, J. 2008. Los Osos Valley (La Canada de Los Osos) the Valley of the Bears. Los Osos, CA: The Bay News.

Sullivan, T. P., \& Sullivan, D. S. (2001). Influence of variable retention harvests on forest ecosystems. II. Diversity and population dynamics of small mammals. Journal of Applied Ecology, 38(6), 1234-1252.

Weltzin, J. F., Archer, S., \& Heitschmidt, R. K. (1997). Small-mammal regulation of vegetation structure in a temperate savanna. Ecology, 78(3), 751-763. 
Western Regional Climate Center (n.d.). Morro Bay Fire Dept, California (045866) period of monthly climate summary. Retrieved May 14, 2014, from http://www.wrcc.dri.edu/cgi-bin/cliMAIN.pl?ca5866

Whitford, W. G., \& Steinberger, Y. (2010). Pack rats ( Neotoma spp.): Keystone ecological engineers? Journal of Arid Environments, 74(11), 1450-1455.

Wilson, D. E., Nichols, J. D., Rudran, R., Southwell, C. (1996). Introduction. In: D. E. Wilson, F. R. Cole, J. D. Nichols, R. Rudran, \& M. S. Foster (Eds). Measuring and monitoring biological diversity: Standard methods for mammals (pp. 1-7). Smithsonian Institution Press, Washington D.C.

Wilson, D. E., \& Reeder, D. M. (Eds.). (2005). Mammal species of the world: a taxonomic and geographic reference (Vol. 12). Baltimore, MD: Johns Hopkins University Press. 
Appendix A: Literature Review Table 
Table 1. Literature review summary of rodent capture analysis: Studies finding both increases and decreases in rodent species in grazed areas.

\begin{tabular}{|c|c|c|c|c|}
\hline Author & Habitat & Management & Trapping Methods & Rodent Results \\
\hline $\begin{array}{c}\text { Bueno et al. } \\
\text { (2011) }\end{array}$ & $\begin{array}{l}\text { Undisclosed habitat } \\
\text { type in Alberta Canada } \\
\text { during } 2007 .\end{array}$ & $\begin{array}{l}\text { No grazing and } \\
\text { continuous } \\
\text { grazing }\end{array}$ & $\begin{array}{l}13 \text { Longworth small mammal live traps } \\
\text { were placed in a grid of an undisclosed } \\
\text { pattern. Bait was a mixture of crushed } \\
\text { oats, sunflower seeds, peanut butter, } \\
\text { apple and synthetic cotton. Captures } \\
\text { marked with numbered ear tag. }\end{array}$ & $\begin{array}{l}\text { Deer mice abundance was } 2 x \text { greater } \\
\text { in the grazed areas. Meadow voles } \\
\text { were captured } 25 x \text { more often in the } \\
\text { ungrazed areas. }\end{array}$ \\
\hline $\begin{array}{c}\text { Bock et al. } \\
\text { (1984) }\end{array}$ & $\begin{array}{l}\text { Semi-desert grassland } \\
\text { in southeastern Arizona } \\
\text { from July, } 1981 \text { through } \\
\text { January, } 1983\end{array}$ & $\begin{array}{l}\text { No grazing and } \\
\text { undisclosed } \\
\text { grazing }\end{array}$ & $\begin{array}{l}\text { One } 600 \text {-m trapline in each grazed and } \\
\text { ungrazed area. Each trapline included } \\
60 \text { Sherman live traps set in pairs at } \\
\text { 20m intervals. Traps were baited with } \\
\text { rolled oats. }\end{array}$ & $\begin{array}{l}\text { Merriam kangaroo rats were captured } \\
\text { approx. } 18 x \text { more often on the grazed } \\
\text { section, while five other species } \\
\text { (hispid pocket mouse, western harvest } \\
\text { mouse, white-footed mouse, southern } \\
\text { grasshopper mouse, and hispid cotton } \\
\text { rat) were trapped (approx. } 2.4 x, 6.5 x \text {, } \\
1.9 x, 5.25 x \text {, and } 2.4 x \text { ) more often in } \\
\text { the non-grazed section. }\end{array}$ \\
\hline $\begin{array}{c}\text { Jones et al. } \\
\text { (2003) }\end{array}$ & $\begin{array}{l}\text { Grassland and mesquite } \\
\text { oak savanna in } \\
\text { southeastern Arizona } \\
\text { during 2001-2003 }\end{array}$ & $\begin{array}{l}\text { no grazing and } \\
\text { undisclosed } \\
\text { grazing }\end{array}$ & $\begin{array}{l}120 \text { Sherman live traps were spaced } \\
10 \mathrm{~m} \text { apart along a } 300-\mathrm{m} \text { transect in } \\
\text { each of four plots. Traps were baited } \\
\text { with cotton and rolled oats. Trapping } \\
\text { occurred for } 3 \text { consecutive nights. } \\
\text { Captures marked by fur clipping or ink }\end{array}$ & $\begin{array}{l}36 \% \text { of mice species from the Muridae } \\
\text { family were more common in the } \\
\text { ungrazed sitesby an estimated average } \\
\text { of } 69 \% .27 \% \text { more Heteromyidae } \\
\text { were trapped on grazed sites. }\end{array}$ \\
\hline $\begin{array}{l}\text { Powers et a } \\
\quad(2011)\end{array}$ & $\begin{array}{l}\text { Meadows containing } \\
\text { forbs in the central } \\
\text { Sierra Nevada } \\
\text { Mountains, California } \\
\text { from June to July, } \\
2009 \text {. }\end{array}$ & $\begin{array}{l}\text { No grazing and } \\
\text { continuous } \\
\text { grazing at same } \\
\text { elevations }\end{array}$ & $\begin{array}{l}\text { Estimated pocket gophers by counting } \\
\text { mounds or tunnels within } 10 \mathrm{~m} \text { x } 100 \mathrm{~m} \\
\text { belt transects. Three belt transects per } \\
\text { study site, set at least } 50 \mathrm{~m} \text { from forest } \\
\text { edge. }\end{array}$ & $\begin{array}{l}\text { Pocket gopher density increased by } \\
14.3 \text { pocket gophers per ha in the } \\
\text { grazed sites over the ungrazed sites. }\end{array}$ \\
\hline
\end{tabular}


Table 2. Literature review summary of rodent capture analysis: Studies finding a decrease of rodent abundance in grazed areas.

\begin{tabular}{|c|c|c|c|c|}
\hline Author & Habitat & Management & Trapping Methods & Rodent Results \\
\hline $\begin{array}{c}\text { Rosenstock } \\
\text { (1996) }\end{array}$ & $\begin{array}{l}\text { Shrubland/Grassland } \\
\text { Habitat in large (100+ } \\
\text { ha) and small }(1+\text { ha) } \\
\text { scales in southcentral } \\
\text { Utah from May } 1 \text { and } \\
\text { June } 31 \text { during 1989- } \\
1991\end{array}$ & $\begin{array}{l}\text { Ungrazed and } \\
\text { deferred grazing } \\
\text { system }\end{array}$ & $\begin{array}{l}\text { Small Sherman live traps spaced } 5 \text { meters } \\
\text { apart on a grid in the patch scale sites. At } \\
\text { the microhabitat sides, } 8 \times 8 \text { grid with } 10 \mathrm{~m} \\
\text { spacing between traps. Trapping occurred } \\
\text { simultaneously. Baiting was a mixture of } \\
\text { rolled oats, peanut butter, and birdseed } \\
\text { with a ball of raw wool. Captures marked } \\
\text { with metal ear tag. }\end{array}$ & $\begin{array}{l}\text { The ungrazed macrohabitat sites } \\
\text { contained } 50 \% \text { more small mammal } \\
\text { species and } 80 \% \text { more small } \\
\text { mammals than the grazed sites. }\end{array}$ \\
\hline $\begin{array}{c}\text { Bock et al. } \\
\text { (2006) }\end{array}$ & $\begin{array}{l}\text { Perennial bunchgrass } \\
\text { with scattered low } \\
\text { shrubs and a variety of } \\
\text { forbs in southeastern } \\
\text { Arizona during 2003- } \\
2005\end{array}$ & $\begin{array}{l}\text { Ungrazed and } \\
\text { rotational } \\
\text { grazing }\end{array}$ & $\begin{array}{l}\text { Thirty-six Sherman live traps baited with } \\
\text { cotton and rolled oats and used ink to } \\
\text { mark their captures. The traps were set in } \\
\text { pairs and evenly spaced along a } 200 \mathrm{~m} \\
\text { trapline. Captures marked with ink. }\end{array}$ & $\begin{array}{l}39 \% \text { greater rodent species richness, } \\
34 \% \text { total abundance in the ungrazed } \\
\text { areas as compared to the grazed } \\
\text { areas }\end{array}$ \\
\hline $\begin{array}{l}\text { Chapman } \\
\text { and Ribic } \\
(2002)\end{array}$ & $\begin{array}{l}\text { Grasses and sedges. } \\
\text { Buffer sites had 10-100 } \\
\text { cm deep litter layer; } \\
\text { grazed areas had 0- } \\
\text { 10cm litter layer. } \\
\text { Located in Wisconsin } \\
\text { during } 1997 \text { and } 1998 .\end{array}$ & $\begin{array}{l}\text { Non-grazed } \\
\text { buffer sites, } \\
\text { MIRG sites, and } \\
\text { continuously } \\
\text { grazed sites }\end{array}$ & $\begin{array}{l}\text { Four } 270 \text {-meter transects at each site for } \\
\text { rodent trapping. Two Sherman live traps } \\
\text { were placed at each trapping location } \\
\text { spaced } 30 \text { meters apart. They baited the } \\
\text { traps with a wild birdseed mixture and } \\
\text { used } 23 \text { medium and } 47 \text { small Sherman } \\
\text { live traps and four } 10 \text {-meter drift fences } \\
\text { with four pitfall traps apiece. Captures } \\
\text { marked with metal ear tag. }\end{array}$ & $\begin{array}{l}1.4 \text { to } 2.3 \text { times more species and } 3 \\
\text { to } 5 \text { times greater small mammal } \\
\text { abundance on the non-grazed buffer } \\
\text { sites than on the MIRG pastures. } \\
\text { They observed an average of } 1.4 \text { to } \\
2.9 \text { times more small mammal } \\
\text { species and an average of } 4.3 \text { to } 7 \\
\text { times more small mammal } \\
\text { abundance on the non-grazed buffer } \\
\text { areas than on the continuously } \\
\text { grazed pastures. }\end{array}$ \\
\hline
\end{tabular}


Table 3. Literature review summary of plant and rodent relationships among grazed and ungrazed areas.

\begin{tabular}{|c|c|c|c|c|}
\hline Author & Habitat & Management & Vegetation Results & Vegetaion/Rodent correlation \\
\hline $\begin{array}{l}\text { Rosenstock } \\
\text { (1996) }\end{array}$ & $\begin{array}{l}\text { Shrubland/Grassland } \\
\text { Habitat in large (100+ } \\
\text { ha) and small (1+ ha) } \\
\text { scales in southcentral } \\
\text { Utah from May } 1 \text { and } \\
\text { June } 31 \text { during 1989- } \\
1991\end{array}$ & $\begin{array}{l}\text { Ungrazed and } \\
\text { deferred grazing } \\
\text { system }\end{array}$ & $\begin{array}{l}\text { Ungrazed patches and macrohabitat } \\
\text { sites had more perennial grass (mean } \\
\text { difference } 7.9 \% \text { and } 7.27 \% \text { ), litter } \\
\text { cover (mean difference } 6.62 \% \text { and } \\
2.36 \% \text { ) \& taller perennial grass (mean } \\
\text { difference } 9.5 \mathrm{~cm} \text { and } 21.27 \text { ) than the } \\
\text { grazed area. There were no differences } \\
\text { in shrub cover and density. }\end{array}$ & No correlation analysis conducted detected \\
\hline $\begin{array}{l}\text { Bock et al. } \\
\text { (2006) }\end{array}$ & $\begin{array}{l}\text { Perennial bunchgrass } \\
\text { with scattered low shrubs } \\
\text { and a variety of forbs in } \\
\text { southeastern Arizona } \\
\text { during 2003-2005 }\end{array}$ & $\begin{array}{l}\text { Ungrazed and } \\
\text { rotational } \\
\text { grazing }\end{array}$ & $\begin{array}{l}\text { The vegetation heights in the ungrazed } \\
\text { area had a mean difference of } 9.7 \text {. }\end{array}$ & $\begin{array}{l}\text { Rodent species richness and total } \\
\text { abundance were positively correlated ( } 3.51 \\
\text { and } 2.48 \text {, respectfully) with vegetation } \\
\text { height, but not with grass basal area or } \\
\text { canopy. } P \text {. maniculatus was negatively } \\
\text { correlated (-2.62) with canopy. } R \text {. megalotis } \\
\text { was positively correlated (2.14) with basal } \\
\text { area. }\end{array}$ \\
\hline $\begin{array}{l}\text { Bock et al. } \\
\text { (1984) }\end{array}$ & $\begin{array}{l}\text { Semi-desert grassland in } \\
\text { southeastern Arizona } \\
\text { from July, } 1981 \text { through } \\
\text { January, } 1983\end{array}$ & $\begin{array}{l}\text { No grazing and } \\
\text { undisclosed } \\
\text { grazing }\end{array}$ & $\begin{array}{l}\text { The ungrazed sites also had } 27.1 \% \\
\text { more cover, } 67 \% \text { thicker thatch, } 37.3 \% \\
\text { taller maximum vegetation height, and } \\
30.5 \% \text { greater vegetation density than } \\
\text { the grazed sites on average. }\end{array}$ & No correlation analysis conducted detected \\
\hline $\begin{array}{l}\text { Jones et al. } \\
\text { (2003) }\end{array}$ & $\begin{array}{l}\text { Grassland and mesquite } \\
\text { oak savanna in } \\
\text { southeastern Arizona } \\
\text { during 2001-2003 }\end{array}$ & $\begin{array}{l}\text { No grazing and } \\
\text { undisclosed } \\
\text { grazing }\end{array}$ & $\begin{array}{l}\text { They also conducted vegetation line } \\
\text { transects and observed } 45 \% \text { more grass } \\
\text { cover and } 25.3 \% \text { more woody plants } \\
\text { than the grazed pasture. }\end{array}$ & $\begin{array}{l}\text { Heteromyidae captures were positively } \\
\text { correlated with the amount of unvegetated } \\
\text { ground ( } \mathrm{r}=0.54 \text { ). Muridae captures (not } P \text {. } \\
\text { maniculatus) had a negative correlation } \\
\text { with unvegetated ground ( } \mathrm{r}=-0.76 \text { ) }\end{array}$ \\
\hline $\begin{array}{l}\text { Powers et } \\
\text { al. (2011) }\end{array}$ & $\begin{array}{l}\text { Meadows in the central } \\
\text { Sierra Nevada } \\
\text { mountains, California } \\
\text { from June to July, } 2009 .\end{array}$ & $\begin{array}{l}\text { No grazing and } \\
\text { continuous } \\
\text { grazing at same } \\
\text { elevations }\end{array}$ & $\begin{array}{l}\text { Ungrazed sites had } 27.1 \% \text { more cover, } \\
67 \% \text { thicker thatch, and } 37.3 \% \text { taller } \\
\text { average maximum vegetation height } \\
\text { than grazed sites on average. }\end{array}$ & $\begin{array}{l}\text { Negative correlations between pocket } \\
\text { gopher captures and vegetation cover }(r=- \\
0.45) \text { and thatch height }(r=-0.66) \text {. }\end{array}$ \\
\hline
\end{tabular}


Appendix B: Photos 


\section{EXAMPLES OF GRASSLAND PLOTS}

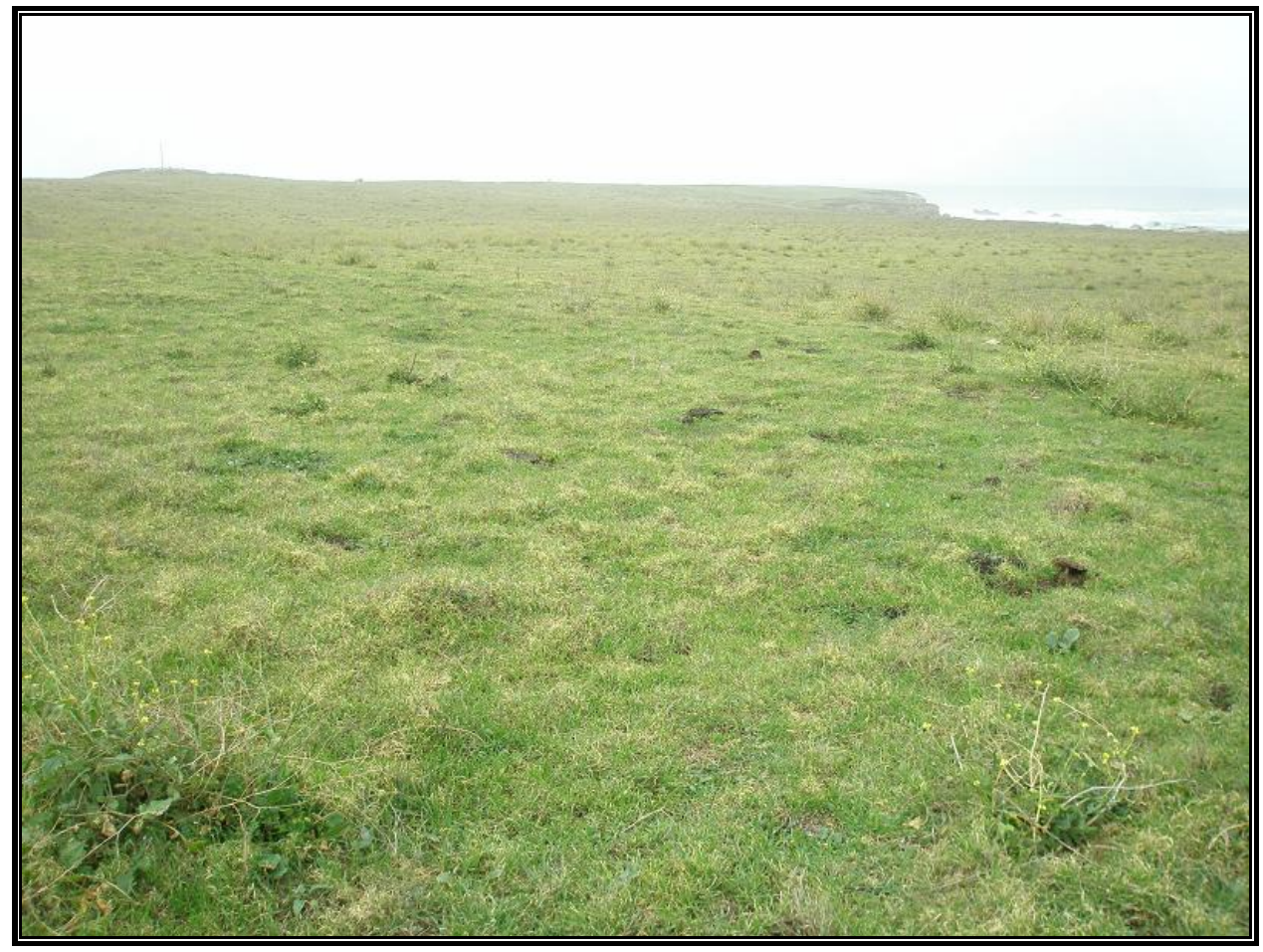

Photo 1. Example of a grazed grassland plot in Pecho Ranch

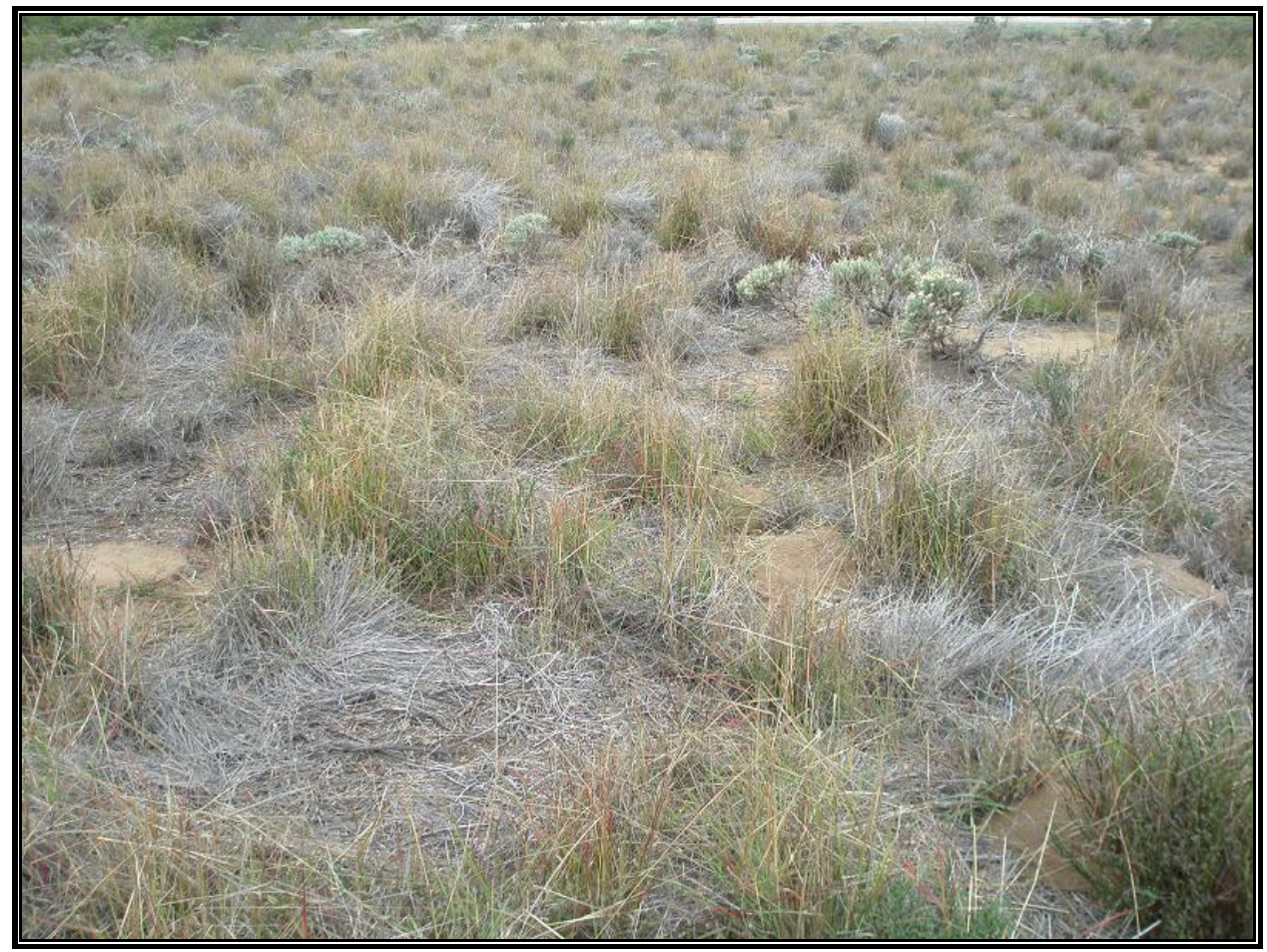

Photo 2. Example of a not grazed grassland plot in Montana De Oro State Park 


\section{EXAMPLES OF SHRUBLAND PLOTS}

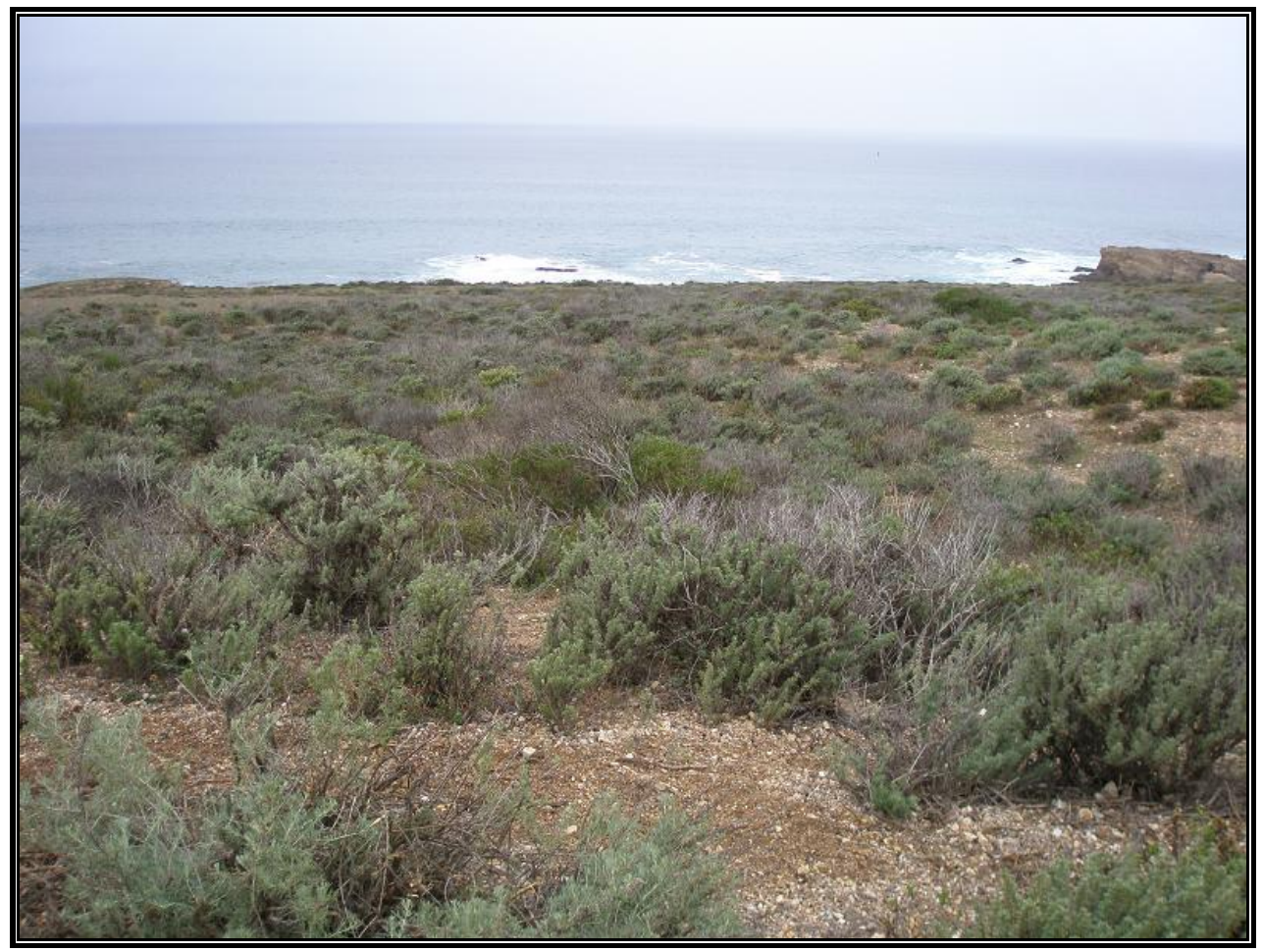

Photo 3. Example of grazed shrubland plot in Pecho Ranch

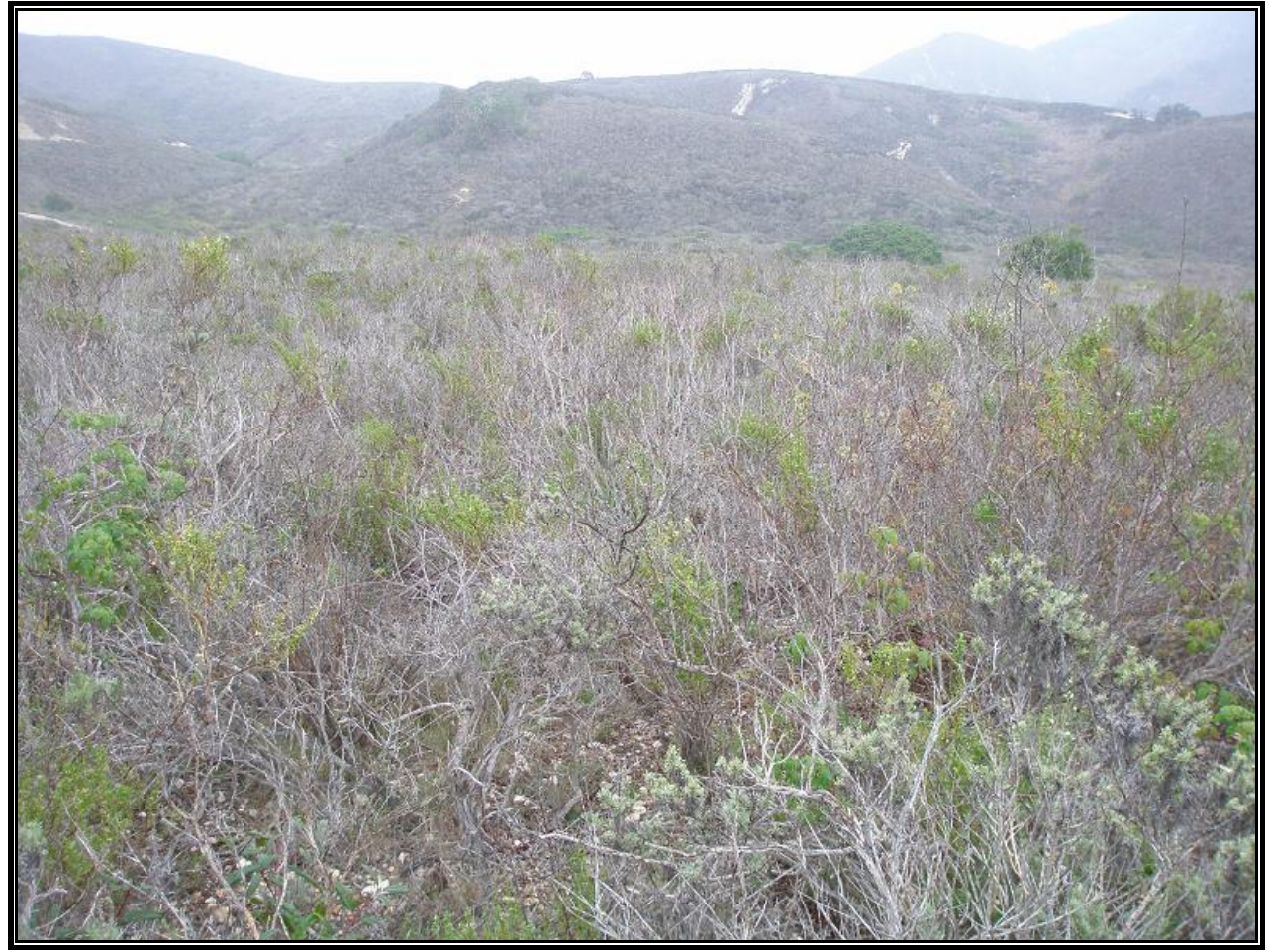

Photo 4. Example of a not-grazed shrubland plot in Montana de Oro State Park 


\section{EXAMPLES OF GRASSLAND/SHRUBLAND MIXED PLOTS}

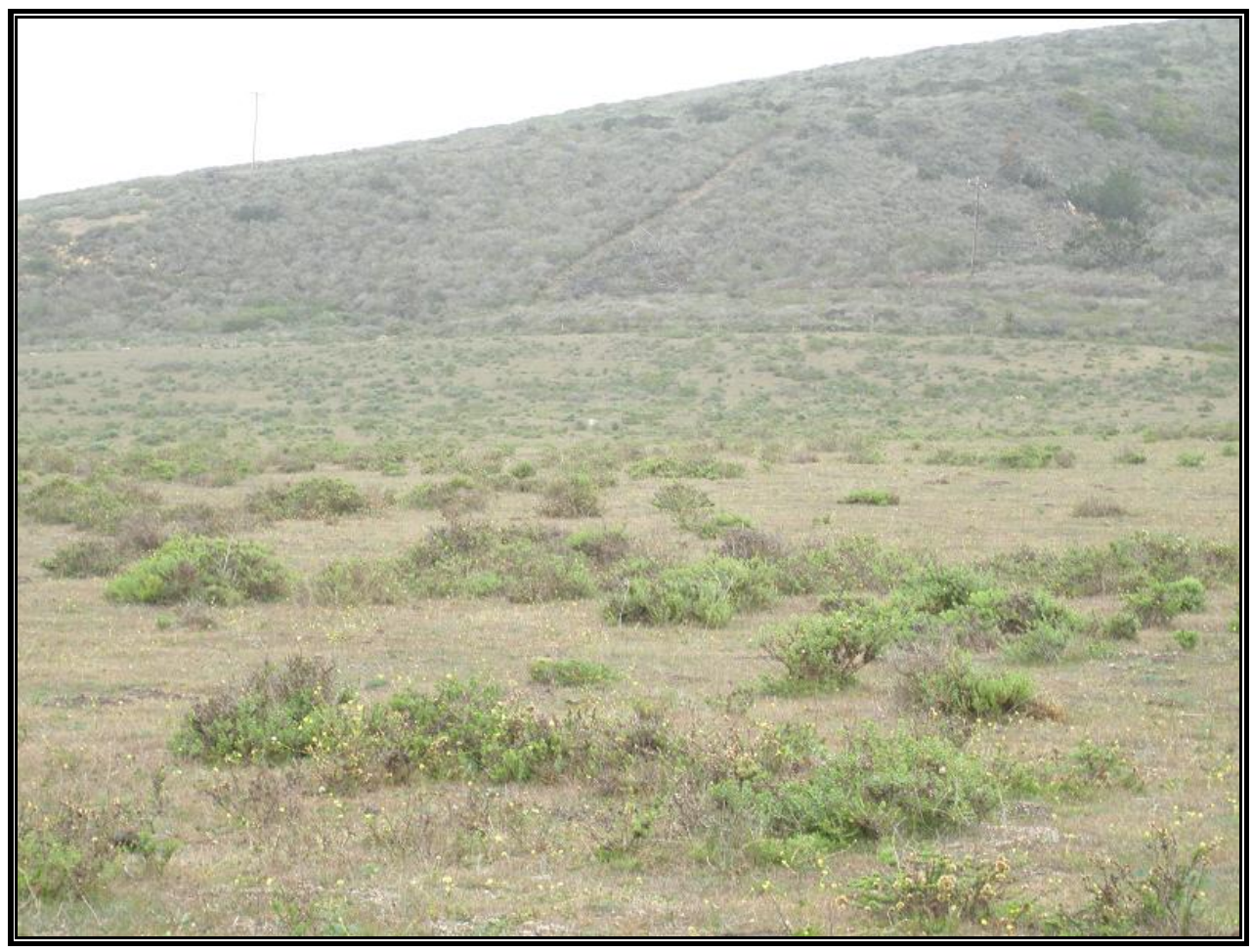

Photo 5. Example of a grazed grassland/shrubland mixed plot in Pecho Ranch

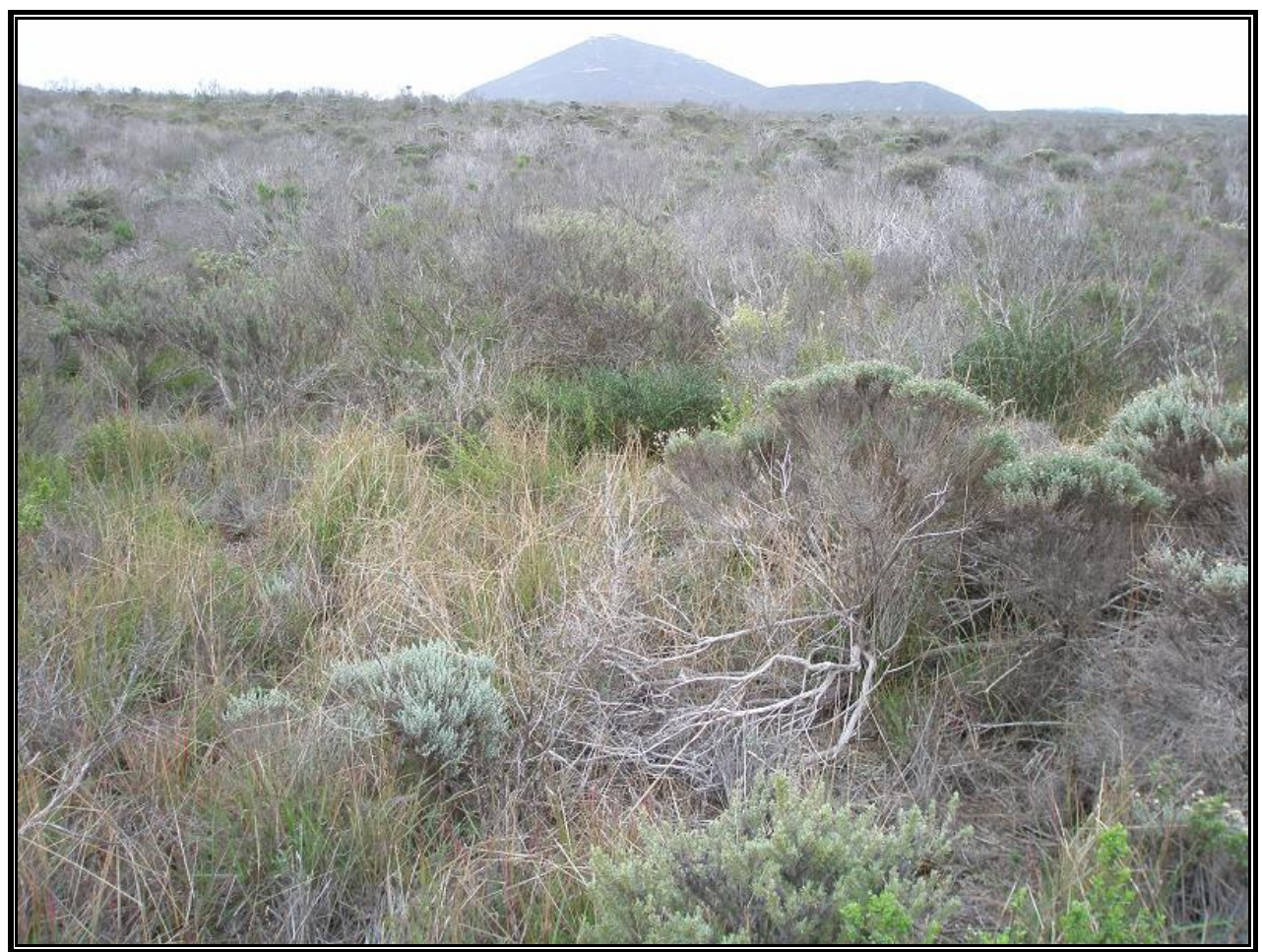

Photo 6. Example of a not- grazed grass/shrub mixed plot in Montana de Oro State Park 


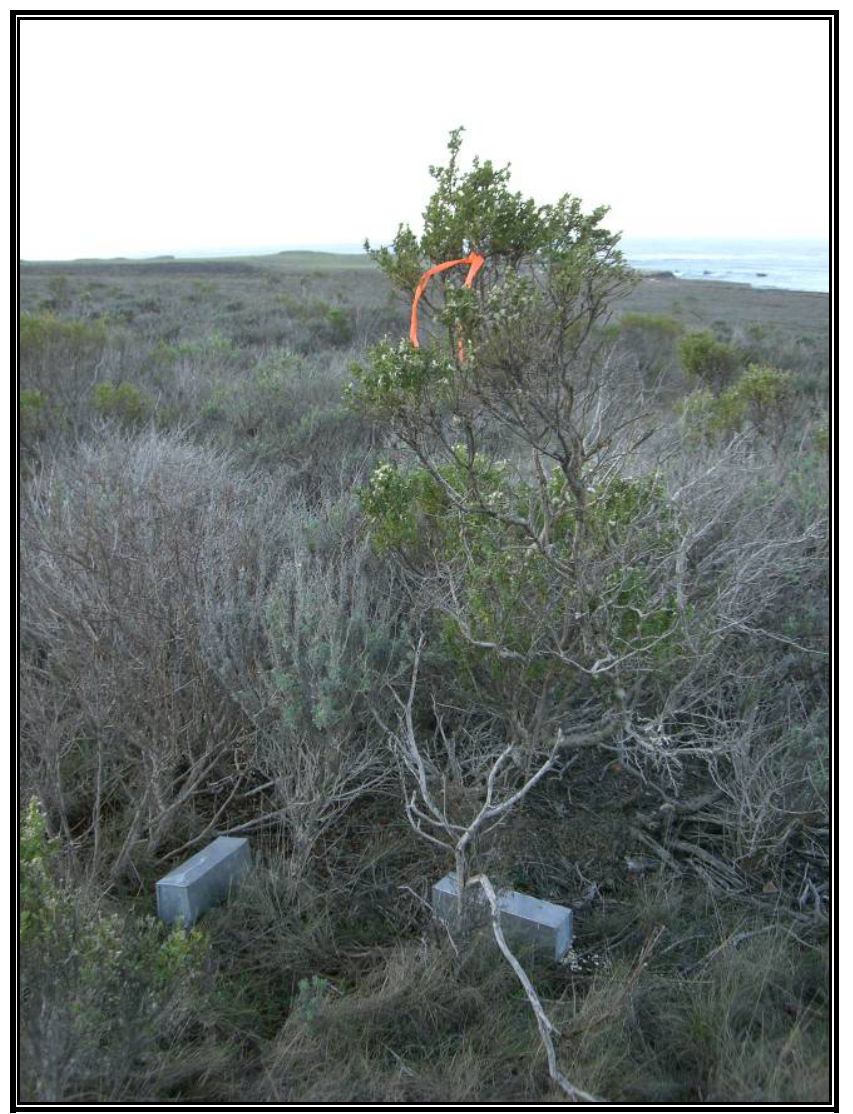

Photo 7. Trapping station within a plot

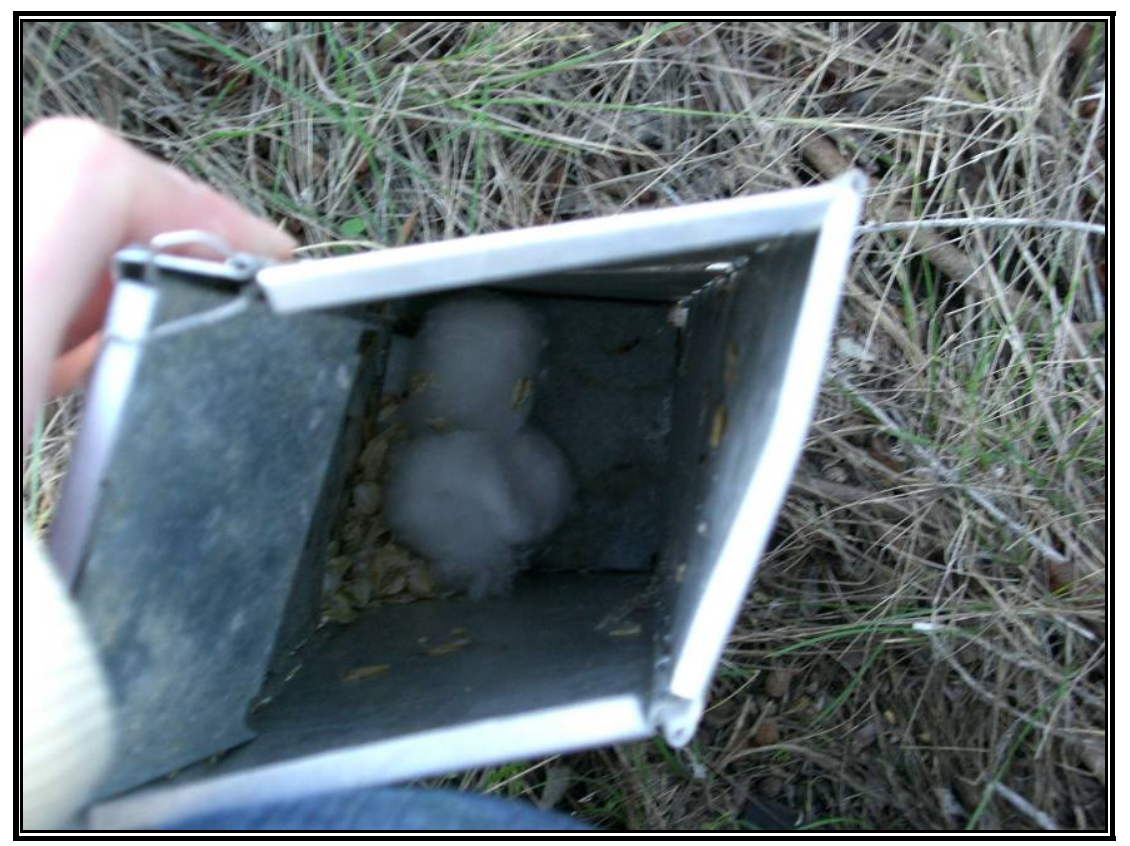

Photo 8. Checking trap for a capture 


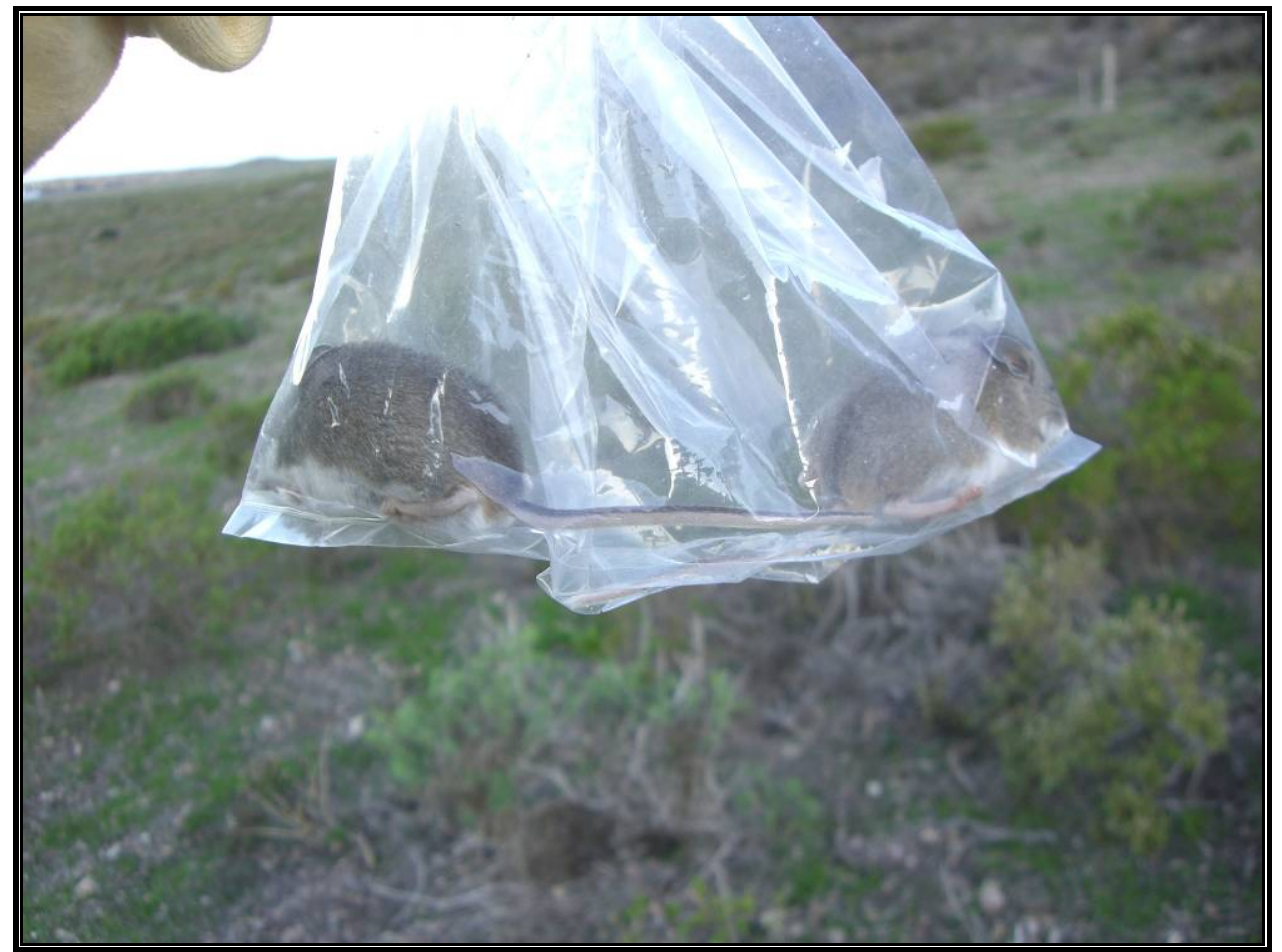

Photo 9. Mice are placed in bags when removed from traps. This is a double capture.

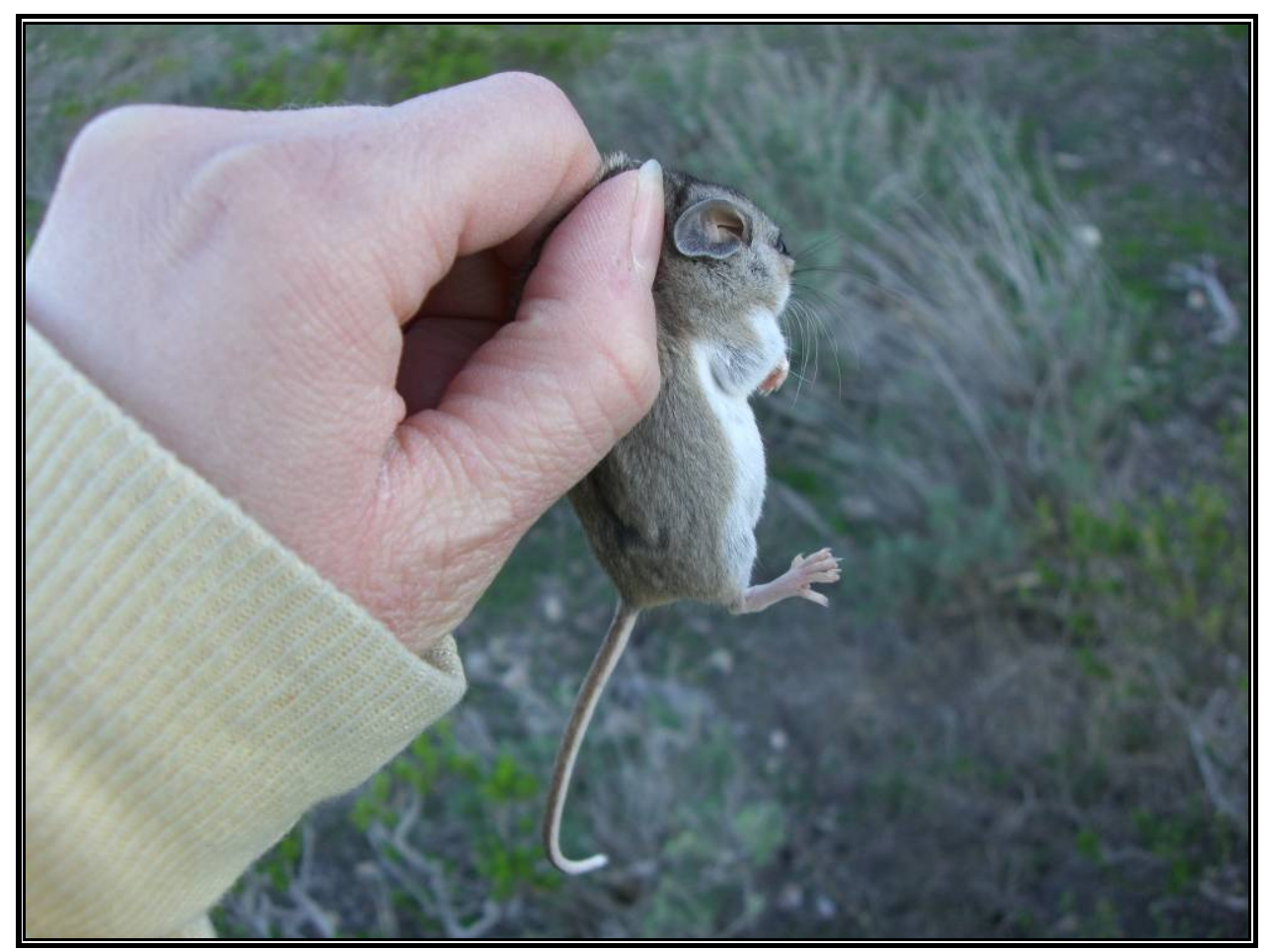

Photo 10. Holding mouse for processing 


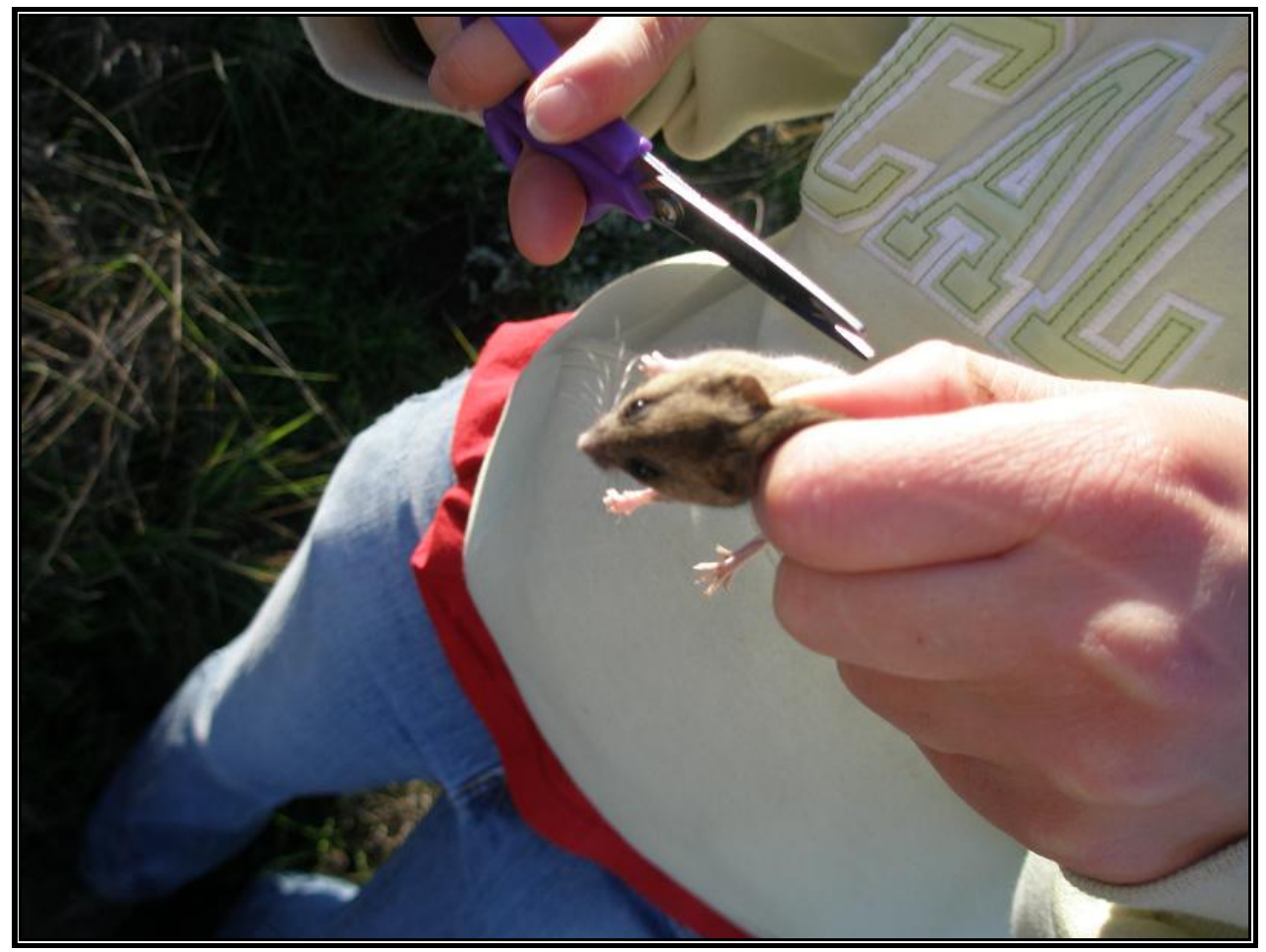

Photo 11. Clipping mouse guard hairs for identification

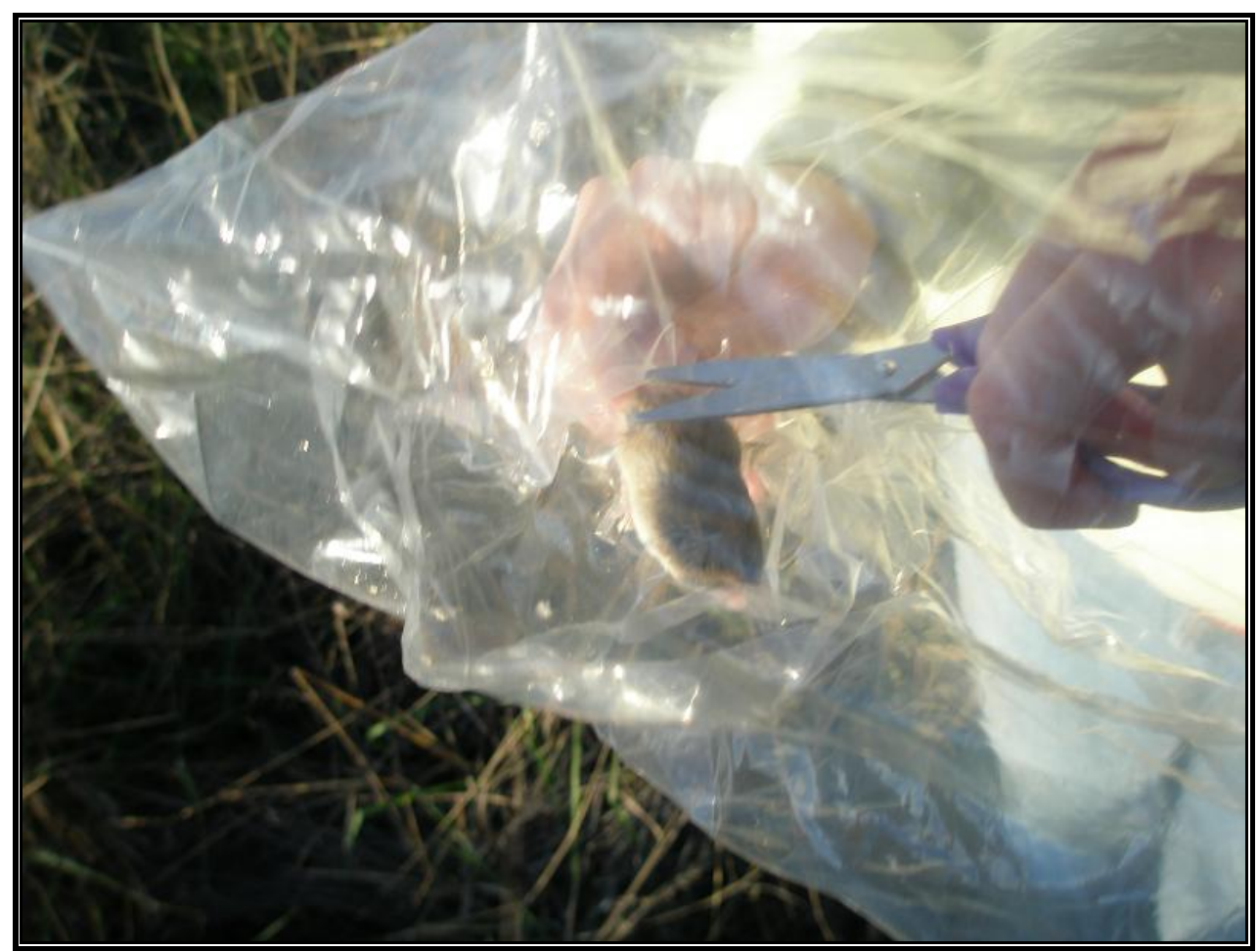

Photo 12. Close up of clipping guard hairs 
TRAPPING PHOTOS CONTINUED

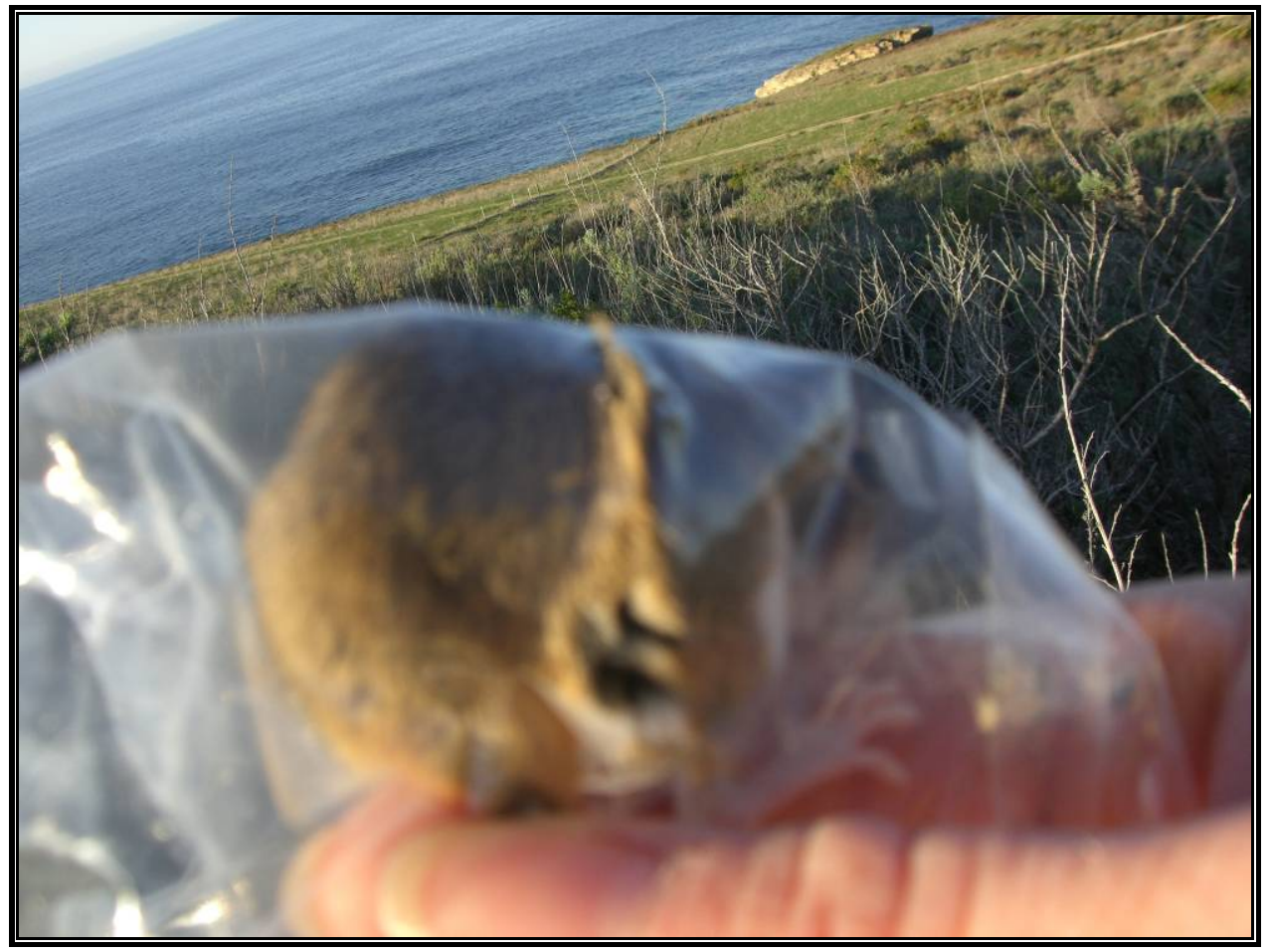

Photo 13. Mouse with guard hairs clipped

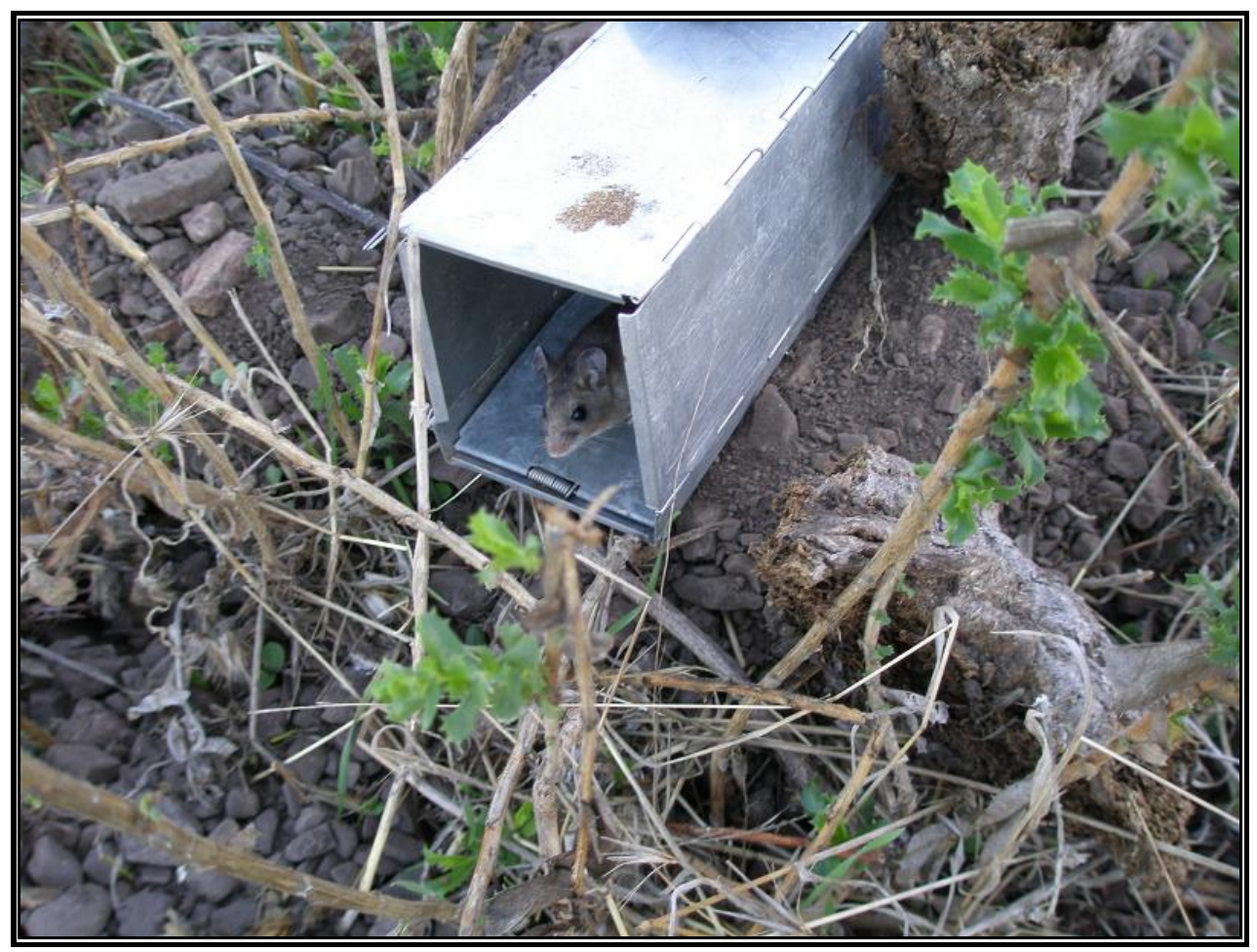

Photo 14. Mouse is released 
Appendix C: Maps 


\section{Montana De Oro State Park Trapping Plots}

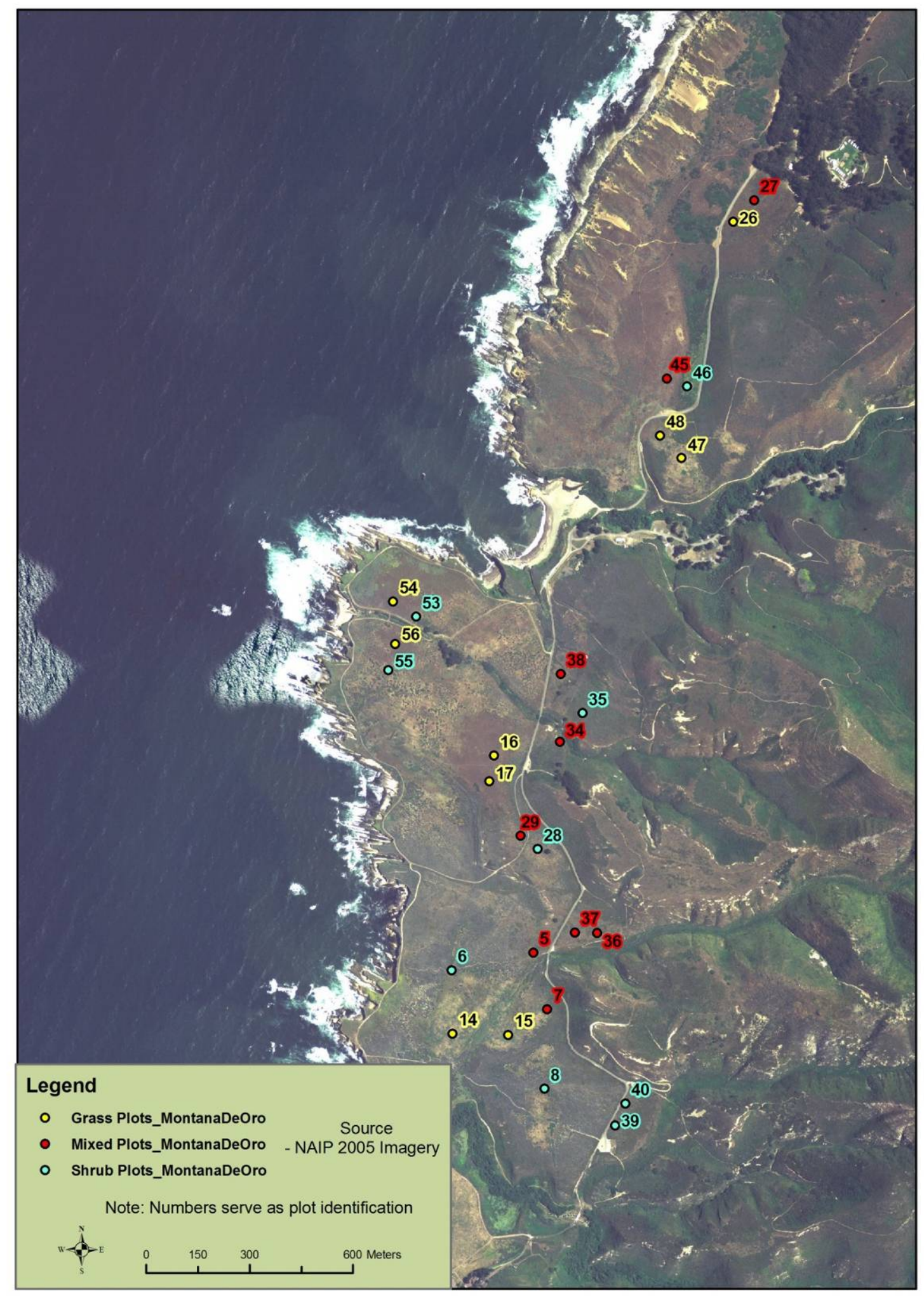




\section{Pecho Ranch Trapping Plots}

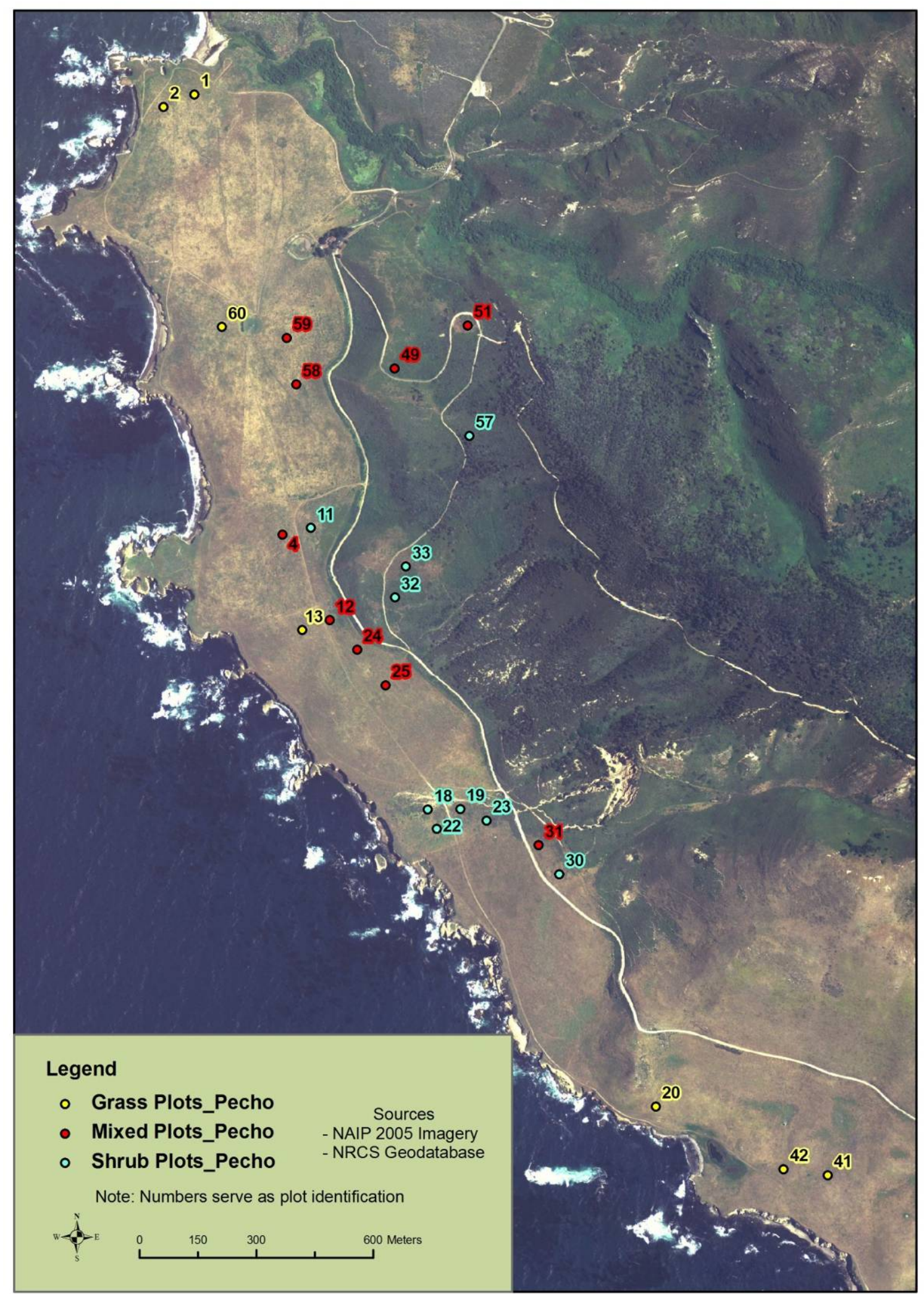




\section{Soils Surrounding State Park Trapping Plots}

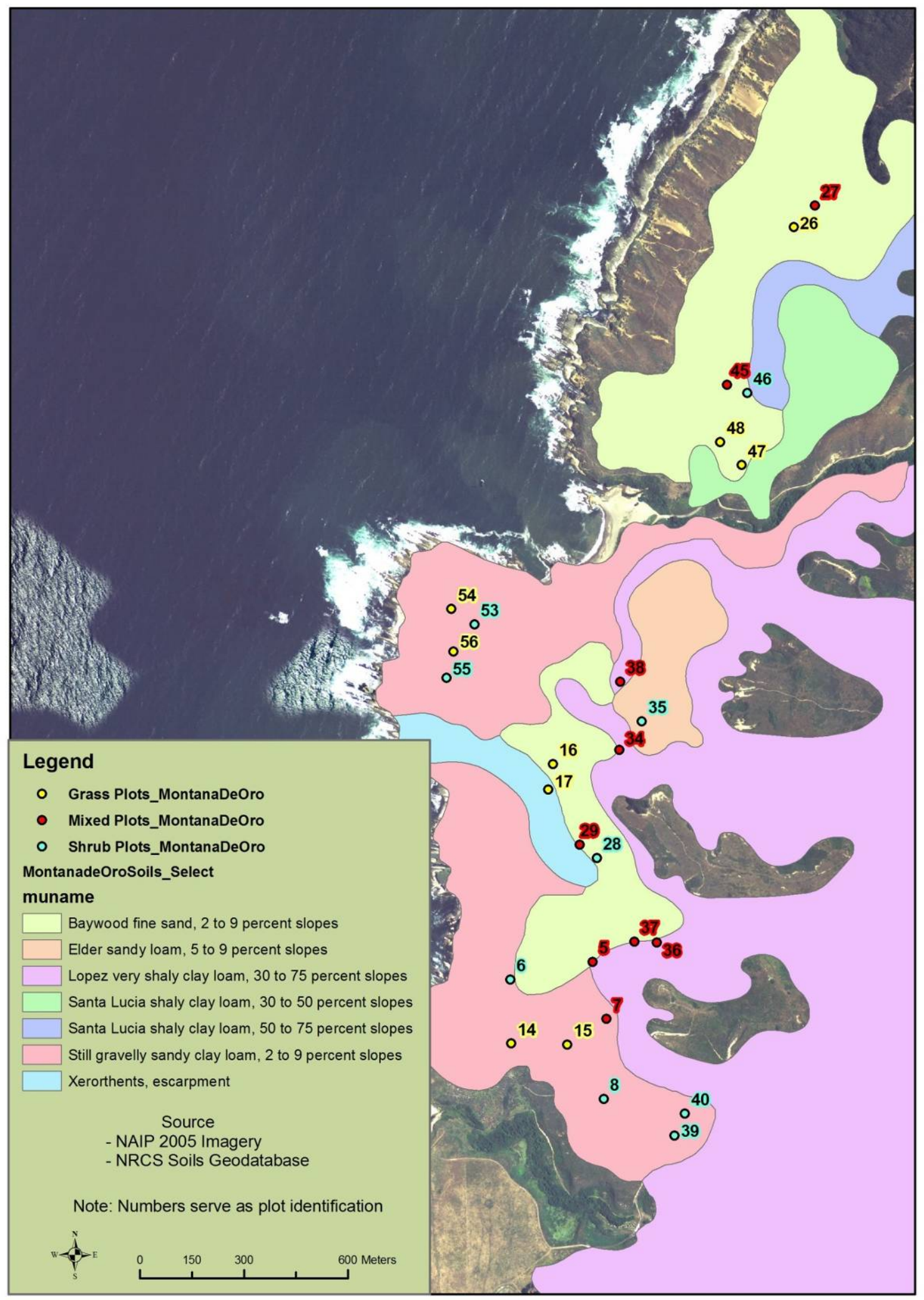




\section{Soils Surrounding Pecho Trapping Plots}

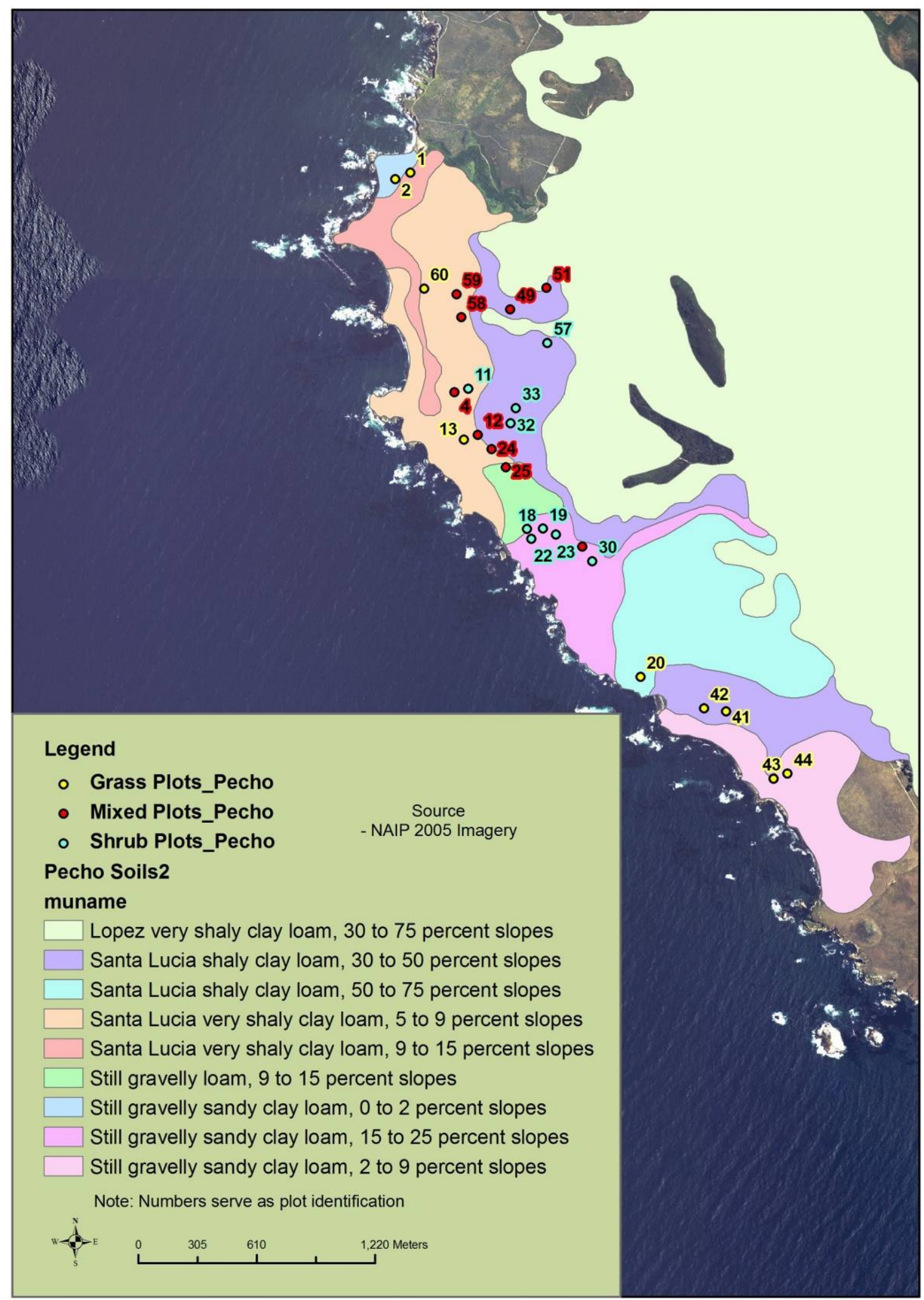




\section{Ecological Sites at State Park}

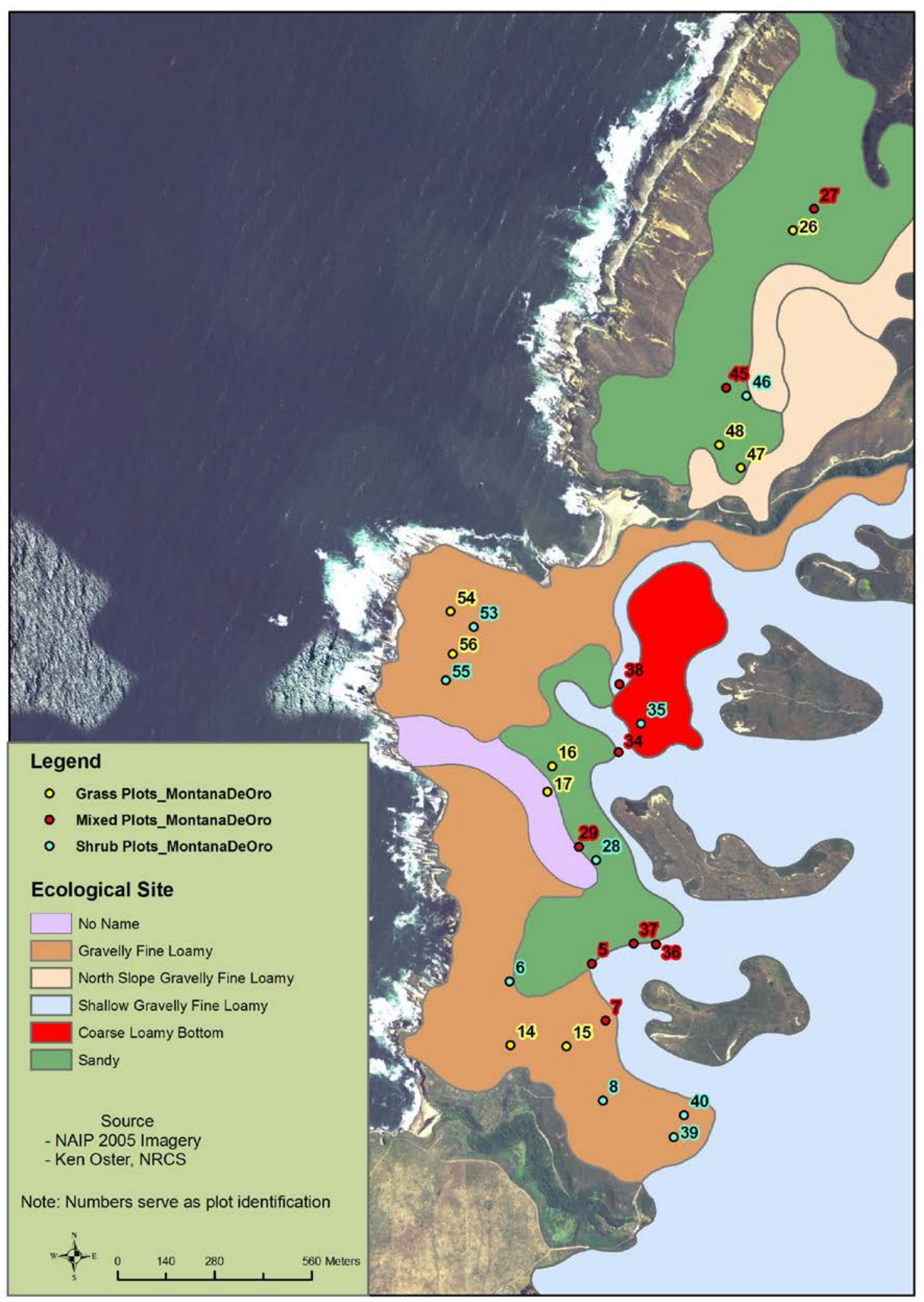




\section{Ecological Sites at Pecho Ranch}

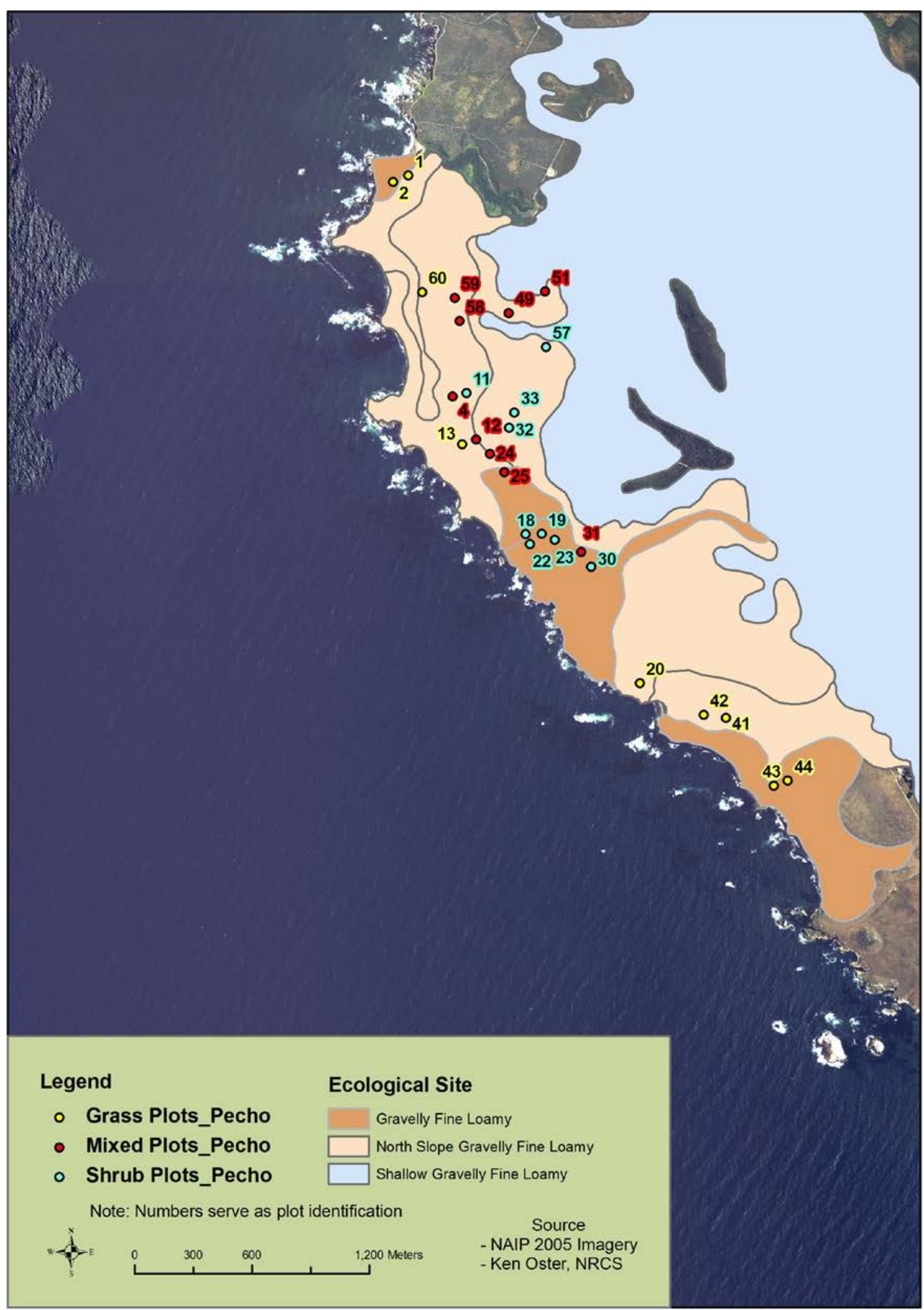


Appendix D: Data Summary 
Summary of trapping data during 486 trapnights.

Plots: the total number of plots containing species out of the 9 plots possible Counts: the total minimum number of species found in each plot per 486 trapnights (i.e. recaptures were not counted).

\begin{tabular}{|c|c|c|c|c|c|c|c|}
\hline \multirow[b]{2}{*}{ Species } & & \multicolumn{3}{|c|}{ Grazed } & \multicolumn{3}{|c|}{ Not Grazed } \\
\hline & & Grass & Mixed & Shrub & Grass & Mixed & Shrub \\
\hline North & Plots & 7 & 9 & 8 & 5 & 9 & 9 \\
\hline $\begin{array}{c}\text { American } \\
\text { deermouse }\end{array}$ & Counts & 17 & 66 & 42 & 54 & 27 & 91 \\
\hline California & Plots & 0 & 1 & 0 & 0 & 0 & 0 \\
\hline deermouse & Counts & 0 & 3 & 0 & 0 & 0 & 0 \\
\hline Brush & Plots & 0 & 2 & 1 & 0 & 3 & 5 \\
\hline deermouse & Counts & 0 & 3 & 3 & 0 & 11 & 16 \\
\hline Dusky- & Plots & 0 & 1 & 4 & 0 & 3 & 4 \\
\hline $\begin{array}{c}\text { footed } \\
\text { woodrat }\end{array}$ & Counts & 0 & 2 & 15 & 0 & 6 & 5 \\
\hline Desert & Plots & 0 & 0 & 2 & 1 & 0 & 0 \\
\hline woodrat & Counts & 0 & 0 & 2 & 1 & 0 & 0 \\
\hline California & Plots & 0 & 1 & 1 & 1 & 2 & 0 \\
\hline vole & Counts & 0 & 2 & 2 & 8 & 2 & 0 \\
\hline California & Plots & 0 & 0 & 2 & 0 & 2 & 3 \\
\hline $\begin{array}{l}\text { Pocket } \\
\text { mouse }\end{array}$ & Counts & 0 & 0 & 3 & 0 & 3 & 3 \\
\hline Western & Plots & 1 & 5 & 2 & 5 & 4 & 3 \\
\hline $\begin{array}{c}\text { Harvest } \\
\text { mouse }\end{array}$ & Counts & 1 & 9 & 9 & 21 & 11 & 4 \\
\hline
\end{tabular}


Shannon's diversity index observation means for each management type and plant community group. $\mathrm{SE}$ is \pm 1 .

\begin{tabular}{|l|c|cccccc|}
\hline \multicolumn{2}{|c|}{} & $\begin{array}{c}\text { Grazed } \\
\text { Grass }\end{array}$ & $\begin{array}{c}\text { Not } \\
\text { Grazed } \\
\text { Grass }\end{array}$ & $\begin{array}{c}\text { Grazed } \\
\text { Mixed }\end{array}$ & $\begin{array}{c}\text { Not } \\
\text { Grazed } \\
\text { Mixed }\end{array}$ & $\begin{array}{c}\text { Grazed } \\
\text { Shrub }\end{array}$ & $\begin{array}{c}\text { Not } \\
\text { Grazed } \\
\text { Shrub }\end{array}$ \\
\hline Shannon's & Mean & 0.05 & 0.44 & 0.72 & 0.27 & 0.74 & 0.58 \\
Diversity Index & SE & \pm 0.05 & \pm 0.11 & \pm 0.12 & \pm 0.14 & \pm 0.09 & \pm 0.14 \\
\hline
\end{tabular}

Observations of mean species counts per 486 trapnights.

\begin{tabular}{|l|c|cccccc|}
\hline \multicolumn{2}{|c|}{} & $\begin{array}{c}\text { Grazed } \\
\text { Grass }\end{array}$ & $\begin{array}{c}\text { Not } \\
\text { Grazed } \\
\text { Grass }\end{array}$ & $\begin{array}{c}\text { Grazed } \\
\text { Mixed }\end{array}$ & $\begin{array}{c}\text { Not } \\
\text { Grazed } \\
\text { Mixed }\end{array}$ & $\begin{array}{c}\text { Grazed } \\
\text { Shrub }\end{array}$ & $\begin{array}{c}\text { Not } \\
\text { Grazed } \\
\text { Shrub }\end{array}$ \\
\hline P. man & Mean & 1.89 & 6 & 7.33 & 3 & 4.67 & 10.11 \\
& SE & \pm 0.59 & \pm 3.69 & \pm 1.43 & \pm 0.75 & \pm 1.24 & \pm 2.84 \\
\hline R. & Mean & 0.11 & 2.33 & 2 & 1.22 & 1 & 1 \\
mega & SE & \pm 0.11 & \pm 1.19 & \pm 0.33 & \pm 0.76 & \pm 0.67 & \pm 0.24 \\
\hline
\end{tabular}




\begin{tabular}{|c|c|c|c|c|c|c|c|c|c|}
\hline Date & New Plot & Management & $\begin{array}{c}\text { Plant } \\
\text { Community }\end{array}$ & $\begin{array}{l}\text { Index H: } \\
\text { sum of } \\
\text { pi[In(pi)] }\end{array}$ & $\begin{array}{l}\text { total } \\
\text { counts }\end{array}$ & S Richness & $\begin{array}{l}\text { Peromyscus } \\
\text { maniculatus }\end{array}$ & $\begin{array}{c}\text { Reithrodontomys } \\
\text { megalotis }\end{array}$ & $\begin{array}{c}\text { Peromyscus } \\
\text { boylii }\end{array}$ \\
\hline Mar 07 & 1 & $\mathrm{G}$ & $\mathrm{G}$ & 0 & 1 & 1 & 1 & 0 & 0 \\
\hline Mar 07 & 2 & $\mathrm{G}$ & $\mathrm{G}$ & 0 & 0 & 0 & 0 & 0 & 0 \\
\hline Jul 07 & 13 & G & $\mathrm{G}$ & 0 & 4 & 1 & 4 & 0 & 0 \\
\hline Oct 07 & 20 & $\mathrm{G}$ & $\mathrm{G}$ & 0 & 1 & 1 & 1 & 0 & 0 \\
\hline Sep 08 & 41 & $\mathrm{G}$ & $\mathrm{G}$ & 0 & 2 & 1 & 2 & 0 & 0 \\
\hline Sep 08 & 42 & $G$ & $\mathrm{G}$ & 0 & 0 & 0 & 0 & 0 & 0 \\
\hline Sep 08 & 43 & $\mathrm{G}$ & $\mathrm{G}$ & 0 & 1 & 1 & 1 & 0 & 0 \\
\hline Sep 08 & 44 & $G$ & $\mathrm{G}$ & 0 & 3 & 1 & 3 & 0 & 0 \\
\hline Feb 09 & 60 & $G$ & $\mathrm{G}$ & 0.4505612 & 6 & 2 & 5 & 1 & 0 \\
\hline Mar 07 & 4 & $\mathrm{G}$ & $\mathrm{M}$ & 0 & 2 & 1 & 2 & 0 & 0 \\
\hline Jul 07 & 12 & $\mathrm{G}$ & $\mathrm{M}$ & 0 & 2 & 1 & 2 & 0 & 0 \\
\hline Jan 08 & 24 & $\mathrm{G}$ & $\mathrm{M}$ & 0.5004024 & 10 & 2 & 8 & 2 & 0 \\
\hline $\operatorname{Jan} 08$ & 25 & $G$ & $\mathrm{M}$ & 0.5982696 & 7 & 2 & 5 & 2 & 0 \\
\hline Jun 08 & 31 & $\mathrm{G}$ & $\mathrm{M}$ & 1.0397208 & 8 & 3 & 4 & 0 & 2 \\
\hline Dec 08 & 49 & $\mathrm{G}$ & $\mathrm{M}$ & 0.6559757 & 14 & 3 & 11 & 2 & 1 \\
\hline Dec 08 & 51 & $\mathrm{G}$ & $\mathrm{M}$ & 0.325083 & 10 & 2 & 9 & 1 & 0 \\
\hline Feb 09 & 58 & $\mathrm{G}$ & $\mathrm{M}$ & 0.429323 & 13 & 2 & 11 & 0 & 0 \\
\hline Feb 09 & 59 & $G$ & $\mathrm{M}$ & 0.3767702 & 16 & 2 & 14 & 2 & 0 \\
\hline Jul 07 & 11 & $\mathrm{G}$ & $S$ & 0.6869616 & 9 & 2 & 5 & 4 & 0 \\
\hline Oct 07 & 18 & $\mathrm{G}$ & $S$ & 0.9556999 & 7 & 3 & 4 & 0 & 0 \\
\hline Oct 07 & 19 & $\mathrm{G}$ & $S$ & 0.7963116 & 7 & 3 & 5 & 0 & 0 \\
\hline Jan 08 & 22 & $\mathrm{G}$ & $S$ & 0.6517566 & 14 & 2 & 9 & 5 & 0 \\
\hline $\operatorname{Jan} 08$ & 23 & $\mathrm{G}$ & $S$ & 0 & 12 & 1 & 12 & 0 & 0 \\
\hline Jun 08 & 30 & $\mathrm{G}$ & $S$ & 0.6931472 & 4 & 2 & 2 & 0 & 0 \\
\hline Jun 08 & 32 & $G$ & $S$ & 0.5859526 & 11 & 2 & 0 & 0 & 3 \\
\hline Jun 08 & 33 & $\mathrm{G}$ & $S$ & 0.6931472 & 6 & 2 & 3 & 0 & 0 \\
\hline Feb 09 & 57 & $\mathrm{G}$ & $S$ & 1.3689224 & 9 & 4 & 2 & 0 & 0 \\
\hline Oct 07 & 14 & $\mathrm{~N}$ & $\mathrm{G}$ & 0 & 0 & 0 & 0 & 0 & 0 \\
\hline Oct 07 & 15 & $\mathrm{~N}$ & $\mathrm{G}$ & 0 & 0 & 0 & 0 & 0 & 0 \\
\hline Oct 07 & 16 & $\mathrm{~N}$ & $\mathrm{G}$ & 0 & 2 & 1 & 0 & 2 & 0 \\
\hline Oct 07 & 17 & $\mathrm{~N}$ & $\mathrm{G}$ & 0 & 1 & 1 & 0 & 1 & 0 \\
\hline
\end{tabular}




\begin{tabular}{|c|c|c|c|c|c|c|c|c|c|}
\hline Date & New Plot & Management & $\begin{array}{c}\text { Plant } \\
\text { Community }\end{array}$ & $\begin{array}{l}\text { Index } H: \\
\text { sum of } \\
\text { pi[ln(pi)] }\end{array}$ & $\begin{array}{l}\text { total } \\
\text { counts }\end{array}$ & S Richness & $\begin{array}{l}\text { Peromyscus } \\
\text { maniculatus }\end{array}$ & $\begin{array}{c}\text { Reithrodontomys } \\
\text { megalotis }\end{array}$ & $\begin{array}{c}\text { Peromyscus } \\
\text { boylii }\end{array}$ \\
\hline $\operatorname{Jan} 08$ & 26 & $\mathrm{~N}$ & $G$ & 0 & 3 & 1 & 3 & 0 & 0 \\
\hline Dec 08 & 47 & $\mathrm{~N}$ & $G$ & 0.9164649 & 11 & 3 & 6 & 4 & 0 \\
\hline Dec 08 & 48 & $\mathrm{~N}$ & $G$ & 0.692013 & 21 & 2 & 10 & 11 & 0 \\
\hline Feb 09 & 54 & $\mathrm{~N}$ & $G$ & 0.8239592 & 12 & 3 & 1 & 3 & 0 \\
\hline Feb 09 & 56 & $\mathrm{~N}$ & $G$ & 0 & 34 & 1 & 34 & 0 & 0 \\
\hline Mar 07 & 5 & $\mathrm{~N}$ & $\mathrm{M}$ & 0.6730117 & 5 & 2 & 3 & 2 & 0 \\
\hline Mar 07 & 7 & $\mathrm{~N}$ & $\mathrm{M}$ & 0.5004024 & 10 & 2 & 8 & 0 & 0 \\
\hline $\operatorname{Jan} 08$ & 27 & $\mathrm{~N}$ & $\mathrm{M}$ & 0.6365142 & 3 & 2 & 2 & 1 & 0 \\
\hline $\operatorname{Jan} 08$ & 29 & $\mathrm{~N}$ & $\mathrm{M}$ & 0.4505612 & 6 & 2 & 5 & 0 & 0 \\
\hline Jun 08 & 34 & $\mathrm{~N}$ & $\mathrm{M}$ & 1.0042425 & 7 & 3 & 1 & 0 & 3 \\
\hline Jun 08 & 36 & $\mathrm{~N}$ & $\mathrm{M}$ & 0.5623351 & 4 & 2 & 3 & 0 & 0 \\
\hline Jun 08 & 37 & $\mathrm{~N}$ & $\mathrm{M}$ & 0.6365142 & 3 & 2 & 1 & 0 & 2 \\
\hline Sep 08 & 38 & $\mathrm{~N}$ & $\mathrm{M}$ & 1.3579779 & 12 & 5 & 2 & 1 & 6 \\
\hline Dec 08 & 45 & $\mathrm{~N}$ & $\mathrm{M}$ & 0.8018186 & 10 & 3 & 2 & 7 & 0 \\
\hline Mar 07 & 8 & $\mathrm{~N}$ & $S$ & 0.8222653 & 16 & 4 & 12 & 0 & 2 \\
\hline $\operatorname{Jan} 08$ & 28 & $\mathrm{~N}$ & $S$ & 0.6365142 & 3 & 2 & 2 & 1 & 0 \\
\hline Mar 07 & 6 & $\mathrm{~N}$ & $S$ & 0.9371559 & 13 & 4 & 9 & 0 & 2 \\
\hline Jun 08 & 35 & $\mathrm{~N}$ & $S$ & 0.8486856 & 9 & 3 & 1 & 0 & 6 \\
\hline Sep 08 & 39 & $\mathrm{~N}$ & $S$ & 0.4505612 & 6 & 2 & 5 & 0 & 1 \\
\hline Sep 08 & 40 & $\mathrm{~N}$ & $S$ & 0 & 6 & 1 & 6 & 0 & 0 \\
\hline Dec 08 & 46 & $\mathrm{~N}$ & $S$ & 1.1966127 & 17 & 5 & 9 & 1 & 5 \\
\hline Feb 09 & 53 & $\mathrm{~N}$ & $S$ & 0 & 27 & 1 & 27 & 0 & 0 \\
\hline Feb 09 & 55 & $\mathrm{~N}$ & $S$ & 0.3046361 & 22 & 2 & 20 & 2 & 0 \\
\hline
\end{tabular}




\begin{tabular}{|c|c|c|c|c|c|c|c|c|}
\hline Date & New Plot & Management & $\begin{array}{c}\text { Plant } \\
\text { Community }\end{array}$ & $\begin{array}{l}\text { Peromyscus } \\
\text { californicus }\end{array}$ & $\begin{array}{l}\text { Neotoma } \\
\text { fuscipes }\end{array}$ & $\begin{array}{c}\text { Neotoma } \\
\text { lepida }\end{array}$ & $\begin{array}{c}\text { Microtus } \\
\text { californicus }\end{array}$ & $\begin{array}{l}\text { Chaetodipus } \\
\text { californicus }\end{array}$ \\
\hline Mar 07 & 1 & $G$ & $G$ & 0 & 0 & 0 & 0 & 0 \\
\hline Mar 07 & 2 & $\bar{G}$ & $G$ & 0 & 0 & 0 & 0 & 0 \\
\hline Jul 07 & 13 & $\mathrm{G}$ & $\mathrm{G}$ & 0 & 0 & 0 & 0 & 0 \\
\hline Oct 07 & 20 & $G$ & $G$ & 0 & 0 & 0 & 0 & 0 \\
\hline Sep 08 & 41 & $\mathrm{G}$ & $\bar{G}$ & 0 & 0 & 0 & 0 & 0 \\
\hline Sep 08 & 42 & $\mathrm{G}$ & $\mathrm{G}$ & 0 & 0 & 0 & 0 & 0 \\
\hline Sep 08 & 43 & $\mathrm{G}$ & $\mathrm{G}$ & 0 & 0 & 0 & 0 & 0 \\
\hline Sep 08 & 44 & $G$ & $\bar{G}$ & 0 & 0 & 0 & 0 & 0 \\
\hline Feb 09 & 60 & $\mathrm{G}$ & $\mathrm{G}$ & 0 & 0 & 0 & 0 & 0 \\
\hline Mar 07 & 4 & $\mathrm{G}$ & $\bar{M}$ & 0 & 0 & 0 & 0 & 0 \\
\hline Jul 07 & 12 & $\bar{G}$ & $\bar{M}$ & 0 & 0 & 0 & 0 & 0 \\
\hline Jan 08 & 24 & $G$ & $\mathrm{M}$ & 0 & 0 & 0 & 0 & 0 \\
\hline $\operatorname{Jan} 08$ & 25 & $G$ & $\mathrm{M}$ & 0 & 0 & 0 & 0 & 0 \\
\hline Jun 08 & 31 & $\mathrm{G}$ & $\bar{M}$ & 0 & 2 & 0 & 0 & 0 \\
\hline Dec 08 & 49 & $G$ & $M$ & 0 & 0 & 0 & 0 & 0 \\
\hline Dec 08 & 51 & $G$ & $\mathrm{M}$ & 0 & 0 & 0 & 0 & 0 \\
\hline Feb 09 & 58 & $G$ & $\mathrm{M}$ & 0 & 0 & 0 & 2 & 0 \\
\hline Feb 09 & 59 & $G$ & $M$ & 0 & 0 & 0 & 0 & 0 \\
\hline Jul 07 & 11 & $G$ & $S$ & 0 & 0 & 0 & 0 & 0 \\
\hline Oct 07 & 18 & $\bar{G}$ & $S$ & 0 & 0 & 1 & 0 & 2 \\
\hline Oct 07 & 19 & $G$ & $S$ & 0 & 0 & 1 & 0 & 1 \\
\hline $\operatorname{Jan} 08$ & 22 & $\bar{G}$ & $S$ & 0 & 0 & 0 & 0 & 0 \\
\hline $\operatorname{Jan} 08$ & 23 & $\bar{G}$ & $S$ & 0 & 0 & 0 & 0 & 0 \\
\hline Jun 08 & 30 & $G$ & $S$ & 0 & 2 & 0 & 0 & 0 \\
\hline Jun 08 & 32 & $\bar{G}$ & $S$ & 0 & 8 & 0 & 0 & 0 \\
\hline Jun 08 & 33 & $\mathrm{G}$ & $S$ & 0 & 3 & 0 & 0 & 0 \\
\hline Feb 09 & 57 & $\mathrm{G}$ & $S$ & 3 & 2 & 0 & 2 & 0 \\
\hline Oct 07 & 14 & $\bar{N}$ & $G$ & 0 & 0 & 0 & 0 & 0 \\
\hline Oct 07 & 15 & $\mathrm{~N}$ & $G$ & 0 & 0 & 0 & 0 & 0 \\
\hline Oct 07 & 16 & $\mathrm{~N}$ & $\mathrm{G}$ & 0 & 0 & 0 & 0 & 0 \\
\hline Oct 07 & 17 & $\bar{N}$ & $\bar{G}$ & 0 & 0 & 0 & 0 & 0 \\
\hline
\end{tabular}




\begin{tabular}{|c|c|c|c|c|c|c|c|c|}
\hline Date & New Plot & Management & $\begin{array}{c}\text { Plant } \\
\text { Community }\end{array}$ & $\begin{array}{l}\text { Peromyscus } \\
\text { californicus }\end{array}$ & $\begin{array}{l}\text { Neotoma } \\
\text { fuscipes }\end{array}$ & $\begin{array}{c}\text { Neotoma } \\
\text { lepida }\end{array}$ & $\begin{array}{c}\text { Microtus } \\
\text { californicus }\end{array}$ & $\begin{array}{l}\text { Chaetodipus } \\
\text { californicus }\end{array}$ \\
\hline Jan 08 & 26 & $\mathrm{~N}$ & $G$ & 0 & 0 & 0 & 0 & 0 \\
\hline Dec 08 & 47 & $\mathrm{~N}$ & $G$ & 0 & 0 & 1 & 0 & 0 \\
\hline Dec 08 & 48 & $\bar{N}$ & $\mathrm{G}$ & 0 & 0 & 0 & 0 & 0 \\
\hline Feb 09 & 54 & $\bar{N}$ & $\bar{G}$ & 0 & 0 & 0 & 8 & 0 \\
\hline Feb 09 & 56 & $\mathrm{~N}$ & $G$ & 0 & 0 & 0 & 0 & 0 \\
\hline Mar 07 & 5 & $\mathrm{~N}$ & $\mathrm{M}$ & 0 & 0 & 0 & 0 & 0 \\
\hline Mar 07 & 7 & $\bar{N}$ & $\bar{M}$ & 0 & 0 & 0 & 0 & 2 \\
\hline $\operatorname{Jan} 08$ & 27 & $\mathrm{~N}$ & $M$ & 0 & 0 & 0 & 0 & 0 \\
\hline $\operatorname{Jan} 08$ & 29 & $\mathrm{~N}$ & $\mathrm{M}$ & 0 & 0 & 0 & 1 & 0 \\
\hline Jun 08 & 34 & $\mathrm{~N}$ & $\mathrm{M}$ & 0 & 3 & 0 & 0 & 0 \\
\hline Jun 08 & 36 & $\mathrm{~N}$ & $\bar{M}$ & 0 & 1 & 0 & 0 & 0 \\
\hline Jun 08 & 37 & $\mathrm{~N}$ & $\mathrm{M}$ & 0 & 0 & 0 & 0 & 0 \\
\hline Sep 08 & 38 & $\mathrm{~N}$ & $M$ & 0 & 2 & 0 & 1 & 0 \\
\hline Dec 08 & 45 & $\bar{N}$ & $\bar{M}$ & 0 & 0 & 0 & 0 & 1 \\
\hline Mar 07 & 8 & $\mathrm{~N}$ & $S$ & 0 & 1 & 0 & 0 & 1 \\
\hline Jan 08 & 28 & $\mathrm{~N}$ & $S$ & 0 & 0 & 0 & 0 & 0 \\
\hline Mar 07 & 6 & $\mathrm{~N}$ & $S$ & 0 & 1 & 0 & 0 & 1 \\
\hline Jun 08 & 35 & $\mathrm{~N}$ & $S$ & 0 & 2 & 0 & 0 & 0 \\
\hline Sep 08 & 39 & $\mathrm{~N}$ & $S$ & 0 & 0 & 0 & 0 & 0 \\
\hline Sep 08 & 40 & $\mathrm{~N}$ & $S$ & 0 & 0 & 0 & 0 & 0 \\
\hline Dec 08 & 46 & $\mathrm{~N}$ & $S$ & 0 & 1 & 0 & 0 & 1 \\
\hline Feb 09 & 53 & $\mathrm{~N}$ & $S$ & 0 & 0 & 0 & 0 & 0 \\
\hline Feb 09 & 55 & $\mathrm{~N}$ & $S$ & 0 & 0 & 0 & 0 & 0 \\
\hline
\end{tabular}


Appendix E: Statistical Output 


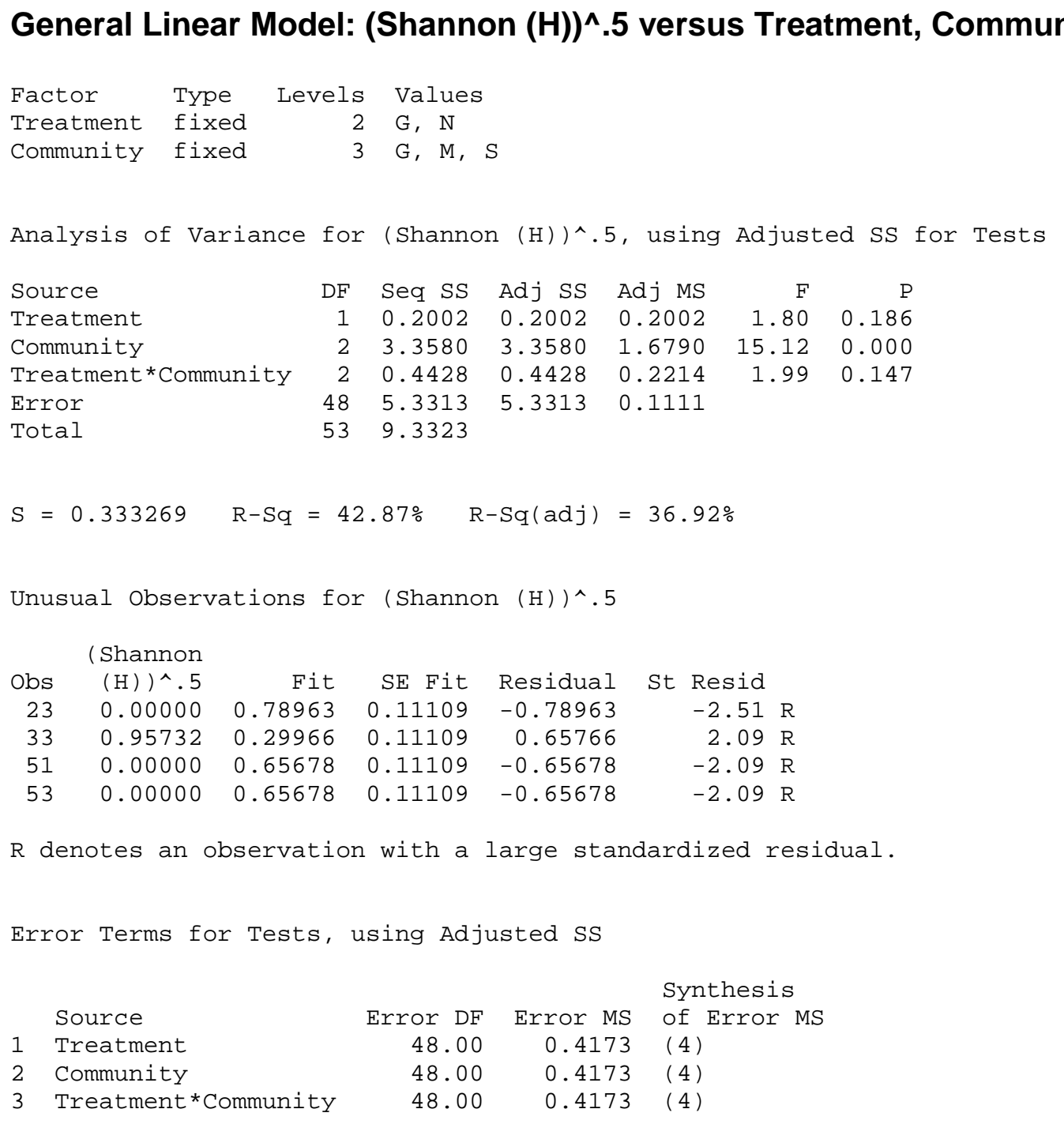




\section{General Linear Model: $(\text { Shannon }(\mathrm{H}))^{\wedge} .5$ versus Treatment, Community}

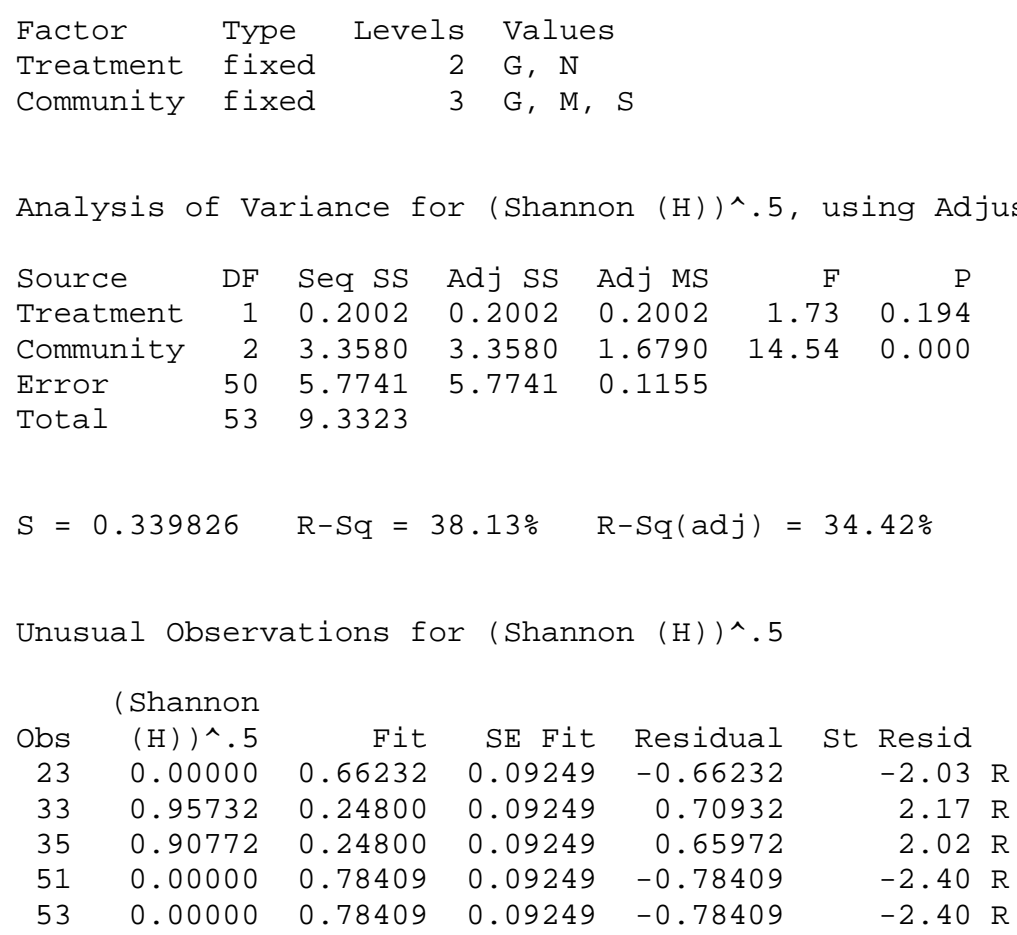

$\mathrm{R}$ denotes an observation with a large standardized residual.

Tukey 95.๑\% Simultaneous Confidence Intervals

Response Variable (Shannon $(\mathrm{H}))^{\wedge} .5$

All Pairwise Comparisons among Levels of Treatment

Treatment $=\mathrm{G}$ subtracted from:

\begin{tabular}{|c|c|c|c|c|}
\hline \multirow[t]{2}{*}{$\begin{array}{l}\text { Treatment } \\
\mathrm{N}\end{array}$} & $\begin{array}{r}\text { Lower } \\
-\odot .0640 \odot\end{array}$ & $\begin{array}{l}\text { Center } \\
0.1218\end{array}$ & $\begin{array}{r}\text { Upper } \\
\odot .3075\end{array}$ & 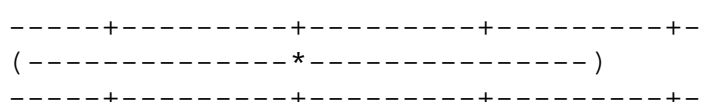 \\
\hline & & & & $\begin{array}{ccc}0.12 & 0.24 & 0.36\end{array}$ \\
\hline
\end{tabular}

Tukey Simultaneous Tests

Response Variable (Shannon $(\mathrm{H}))^{\wedge} .5$

All Pairwise Comparisons among Levels of Treatment

Treatment $=\mathrm{G}$ subtracted from:

$\begin{array}{lrrrr} & \text { Difference } & \text { SE of } & \text { Adjusted } \\ \text { Treatment } & \text { of Means } & \text { Difference } & \text { T-Value } & \text { P-Value } \\ \mathrm{N} & 0.1218 & 0.09249 & 1.317 & 0.1940\end{array}$


Tukey 95.๑\% Simultaneous Confidence Intervals

Response Variable (Shannon $(\mathrm{H}))^{\wedge} .5$

All Pairwise Comparisons among Levels of Community

Community $=\mathrm{G}$ subtracted from:

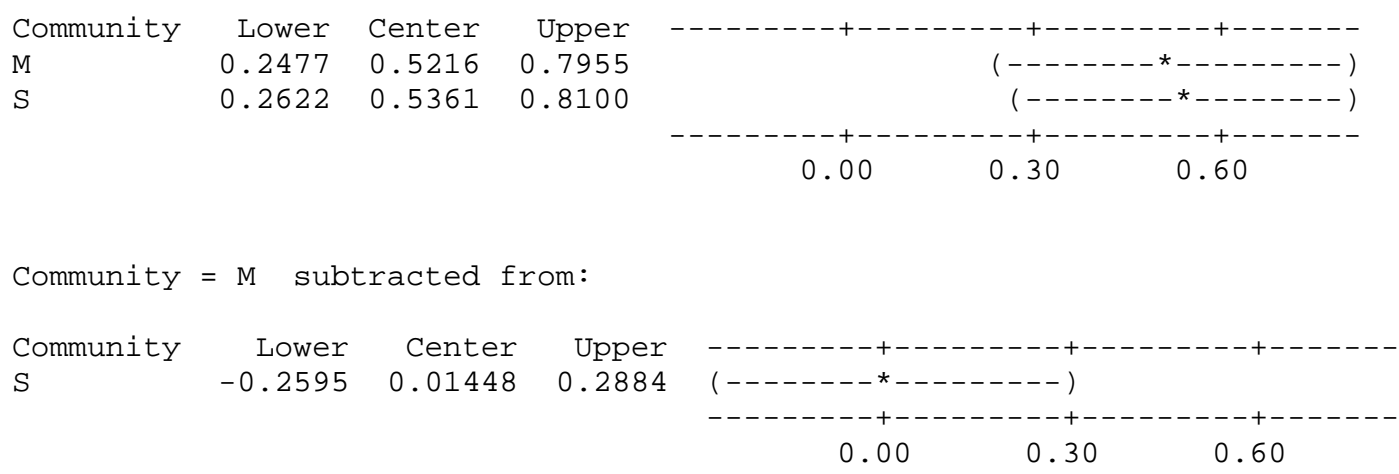

Tukey Simultaneous Tests

Response Variable (Shannon $(\mathrm{H}))^{\wedge} .5$

All Pairwise Comparisons among Levels of Community

Community $=\mathrm{G}$ subtracted from:

$\begin{array}{lrrrr} & \text { Difference } & \text { SE of } & \text { Adjusted } \\ \text { Community } & \text { of Means } & \text { Difference } & \text { T-Value } & \text { P-Value } \\ \text { M } & 0.5216 & 0.1133 & 4.605 & 0.0001 \\ \text { S } & 0.5361 & 0.1133 & 4.733 & 0.0001\end{array}$

Community $=M$ subtracted from:

$\begin{array}{lrrrr} & \text { Difference } & \text { SE of } & \text { Adjusted } \\ \text { Community } & \text { of Means } & \text { Difference } & \text { T-Value } & \text { P-Value } \\ \text { S } & 0.01448 & \odot .1133 & \odot .1278 & \odot .9910\end{array}$

\section{Residual Plots for (Shannon $(\mathrm{H}))^{\wedge} .5$}

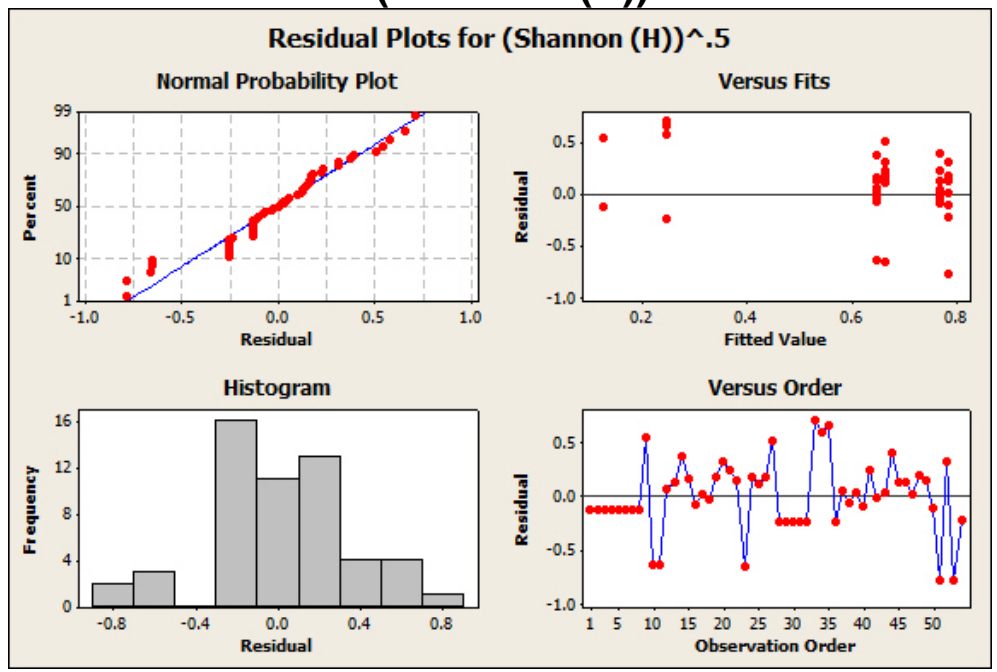




\section{Test for Equal Variances for (Shannon $(\mathrm{H}))^{\wedge} .5$}

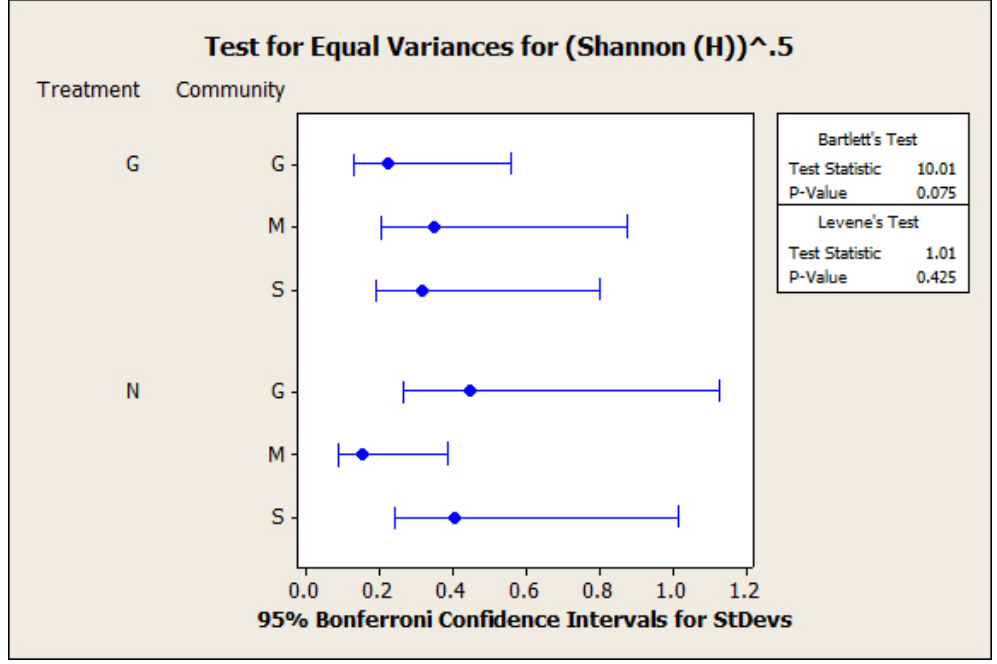

\section{Probability Plot for $(\text { Shannon }(\mathrm{H}))^{\wedge} .5$}

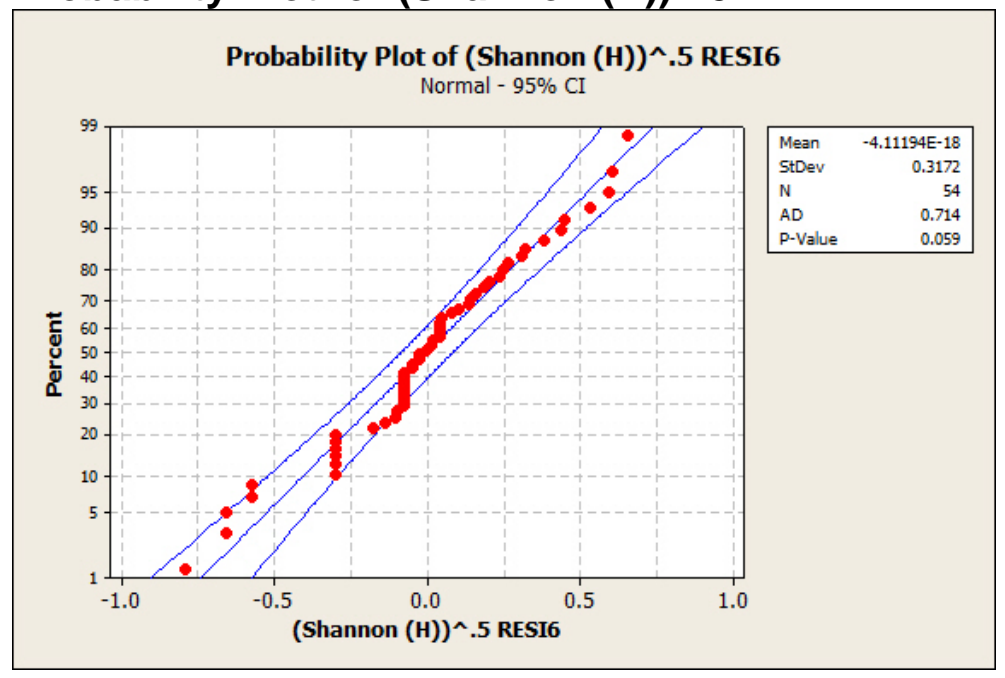




\section{Results: Peromyscus Maniculatus}

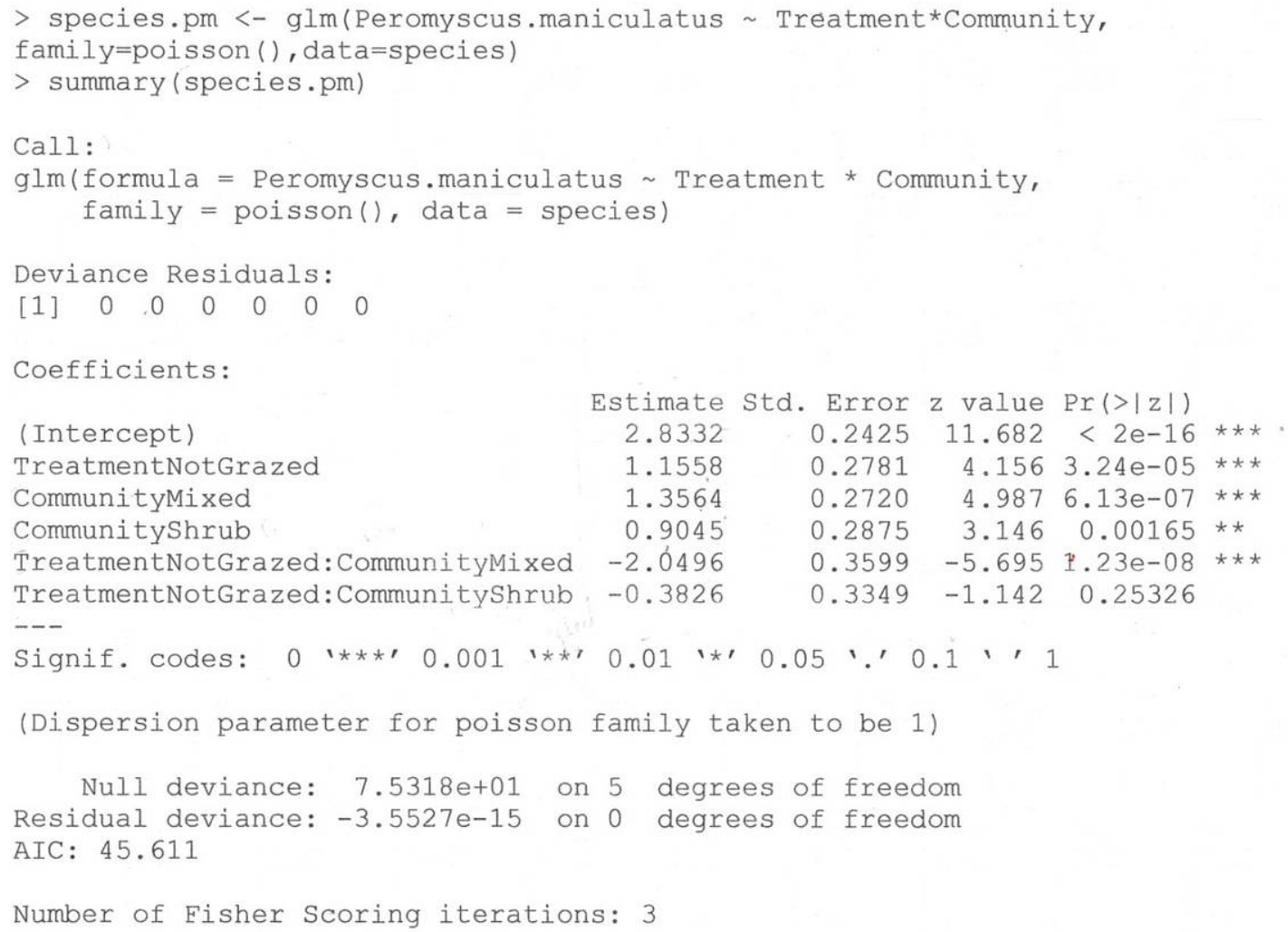

\section{Results: Reithrodontomys megalotis}

$>\operatorname{summary}($ species.pm)

Call:

glm(formula = Reithrodontomys.megalotis Treatment * Community, family $=$ poisson(), data = species)

Deviance Residuals:

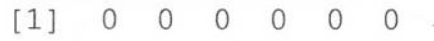

Coefficients:

(Intercept)

TreatmentNotGrazed

CommunityMixed

Communityshrub

$4.676 \mathrm{e}-11 \quad 1.000 \mathrm{e}+00 \quad 4.68 \mathrm{e}-11 \quad 1.00000$

$2.197 \mathrm{e}+00 \quad 1.054 \mathrm{e}+00$

TreatmentNotGrazed:CommunityMixed $-2.844 \mathrm{e}+00 \quad 1.118 \mathrm{e}+00$

TreatmentNotGrazed:CommunityShrub $-3.855 e+00 \quad 1.187 e+00$

$2.9750 .00293 * *$

$2.0840 .03712 *$

$2.0840 .03712 *$

$---$

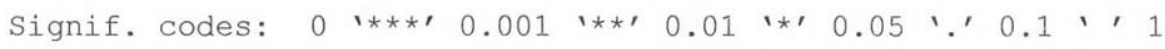

(Dispersion parameter for poisson family taken to be 1)

Null deviance: $2.7101 e+01$ on 5 degrees of freedom

Residual deviance: $-2.1864 \mathrm{e}-21$ on 0 degrees of freedom

AIC: 34.514 
Poisson Regression Results

\section{Model Information}

\begin{tabular}{|l|l|}
\hline Dependent Variable & Peromyscusmaniculatus \\
Probability Distribution & Poisson \\
Link Function & Log \\
\hline
\end{tabular}

\section{Case Processing Summary}

\begin{tabular}{|l|r|r|}
\hline & $\mathrm{N}$ & \multicolumn{1}{|c|}{ Percent } \\
\hline Included & 54 & $48.2 \%$ \\
Excluded & 58 & $51.8 \%$ \\
Total & 112 & $100.0 \%$ \\
\hline
\end{tabular}

\section{Categorical Variable Information}

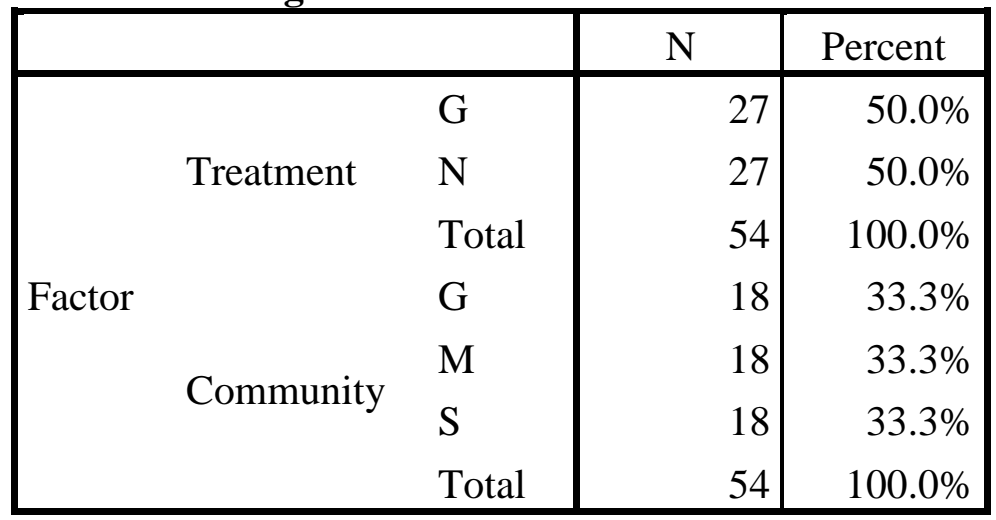


Continuous Variable Information

\begin{tabular}{|lc|r|r|r|r|r|}
\hline & N & Minimum & Maximum & \multicolumn{1}{c|}{ Mean } & Std. Deviation \\
\hline Dependent Variable & Peromyscusmaniculatus & 54 & 0 & 34 & 5.50 & 6.570 \\
\hline
\end{tabular}

\begin{tabular}{|l|r|r|r|}
\hline & Goodness of Fit \\
\hline & Value & df & Value/df \\
\hline Deviance & 249.880 & 48 & 5.206 \\
Scaled Deviance & 249.880 & 48 & \\
Pearson Chi-Square & 291.142 & 48 & 6.065 \\
Scaled Pearson Chi-Square & 291.142 & 48 & \\
Log Likelihood & -202.811 & & \\
Akaike's Information & 417.621 & & \\
Criterion (AIC) & & & \\
Finite Sample Corrected & 419.409 & & \\
AIC (AICC) & & & \\
Bayesian Information & 429.555 & & \\
Criterion (BIC) & & & \\
Consistent AIC (CAIC) & 435.555 & & \\
\hline
\end{tabular}

Dependent Variable: Peromyscusmaniculatus

Model: (Intercept), Treatment, Community, Treatment *

Community

a. Information criteria are in small-is-better form.

b. The full log likelihood function is displayed and used in computing information criteria. 
Omnibus Test ${ }^{\mathrm{a}}$

\begin{tabular}{|r|r|r|}
\hline $\begin{array}{c}\text { Likelihood } \\
\text { Ratio Chi- } \\
\text { Square }\end{array}$ & df & \multicolumn{1}{c|}{ Sig. } \\
\hline 75.318 & & 5 \\
\hline
\end{tabular}

Dependent Variable:

Peromyscusmaniculatus

Model: (Intercept), Treatment,

Community, Treatment * Community

a. Compares the fitted model against the intercept-only model.

Tests of Model Effects

\begin{tabular}{|l|r|r|r|}
\hline \multirow{2}{*}{ Source } & \multicolumn{3}{|c|}{ Type III } \\
\cline { 2 - 4 } & $\begin{array}{c}\text { Wald Chi- } \\
\text { Square }\end{array}$ & df & \multicolumn{1}{c|}{ Sig. } \\
\hline (Intercept) & 534.602 & 1 & .000 \\
Treatment & 6.521 & 1 & .011 \\
Community & 19.489 & 2 & .000 \\
Treatment * Community & 43.159 & 2 & .000 \\
\hline
\end{tabular}

Dependent Variable: Peromyscusmaniculatus

Model: (Intercept), Treatment, Community, Treatment *

Community 
Parameter Estimates

\begin{tabular}{|c|c|c|c|c|c|c|c|}
\hline \multirow[t]{2}{*}{ Parameter } & \multirow[t]{2}{*}{$\mathrm{B}$} & \multirow[t]{2}{*}{ Std. Error } & \multicolumn{2}{|c|}{$\begin{array}{l}\text { 95\% Wald Confidence } \\
\text { Interval }\end{array}$} & \multicolumn{3}{|c|}{ Hypothesis Test } \\
\hline & & & Lower & Upper & $\begin{array}{l}\text { Wald Chi- } \\
\text { Square }\end{array}$ & $\mathrm{df}$ & Sig. \\
\hline (Intercept) & 2.314 & .1048 & 2.108 & 2.519 & 487.114 & 1 & .000 \\
\hline [Treatment=G] & -.773 & .1865 & -1.139 & -.408 & 17.180 & 1 & .000 \\
\hline [Treatment=N] & $0^{\mathrm{a}}$ & & & & & . & \\
\hline [Community=G] & -.522 & .1718 & -.859 & -.185 & 9.230 & 1 & .002 \\
\hline [Community=M] & -1.215 & .2191 & -1.645 & -.785 & 30.739 & 1 & .000 \\
\hline [Community=S] & & & & & & . & \\
\hline [Treatment=G] * & -.383 & .3349 & -1.039 & .274 & 1.305 & 1 & .253 \\
\hline [Community=G] & & & & & & & \\
\hline$[$ Treatment=G] * & 1.667 & .2949 & 1.089 & 2.245 & 31.946 & 1 & .000 \\
\hline [Community=M] & & & & & & & \\
\hline$[$ Treatment=G] * & $0^{\mathrm{a}}$ & & & & & & \\
\hline [Community=S] & & & & & & & \\
\hline$[$ Treatment=N] * & $0^{\mathrm{a}}$ & & & . & & & \\
\hline [Community=G] & & & & & & & \\
\hline [Treatment=N] * & $0^{\mathrm{a}}$ & & & 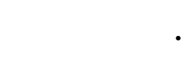 & • & . & . \\
\hline [Community=M] & & & & & & & \\
\hline$[$ Treatment $=\mathrm{N}] *$ & $0^{\mathrm{a}}$ & & & & & & \\
\hline [Community=S] & & & & & & & \\
\hline (Scale) & $1^{b}$ & & & & & & \\
\hline
\end{tabular}


Dependent Variable: Peromyscusmaniculatus

Model: (Intercept), Treatment, Community, Treatment * Community

a. Set to zero because this parameter is redundant.

b. Fixed at the displayed value. 
Estimated Marginal Means 1: Treatment

Estimates

\begin{tabular}{|l|r|r|r|r|}
\hline \multirow{2}{*}{ Treatment } & \multicolumn{1}{|c|}{ Mean } & Std. Error & \multicolumn{1}{|c|}{ 95\% Wald Confidence Interval } \\
\cline { 4 - 5 } & & & \multicolumn{1}{c|}{ Lower } & \multicolumn{1}{c|}{ Upper } \\
\hline G & 4.01 & .418 & 3.27 & 4.92 \\
$\mathrm{~N}$ & 5.67 & .487 & 4.79 & 6.71 \\
\hline
\end{tabular}

Pairwise Comparisons

\begin{tabular}{|ll|r|r|r|r|r|r|}
\hline (I) Treatment & (J) Treatment & $\begin{array}{c}\text { Mean } \\
\text { Difference (I-J) }\end{array}$ & Std. Error & df & \multicolumn{2}{|c|}{ Sig. } & \multicolumn{2}{|c|}{$\begin{array}{c}\text { W5\% Wald Confidence Interval } \\
\text { for Difference }\end{array}$} \\
\cline { 5 - 8 } & & & & & \multicolumn{2}{|c|}{ Lower } & Upper \\
\hline $\mathrm{G}$ & $\mathrm{N}$ & $-1.65^{\mathrm{a}}$ & .642 & 1 & .010 & -2.91 & -.39 \\
$\mathrm{~N}$ & $\mathrm{G}$ & $1.65^{\mathrm{a}}$ & .642 & 1 & .010 & .39 & 2.91 \\
\hline
\end{tabular}

Pairwise comparisons of estimated marginal means based on the original scale of dependent variable Peromyscusmaniculatus

a. The mean difference is significant at the .05 level. 
Overall Test Results

\begin{tabular}{|r|r|r|}
\hline $\begin{array}{c}\text { Wald Chi- } \\
\text { Square }\end{array}$ & df & \multicolumn{1}{c|}{ Sig. } \\
\hline 6.631 & & .010 \\
\hline
\end{tabular}

The Wald chi-square tests the effect of

Treatment. This test is based on the

linearly independent pairwise

comparisons among the estimated

marginal means.

Estimated Marginal Means 2: Community

Estimates

\begin{tabular}{|l|r|r|r|r|}
\hline Community & Mean & Std. Error & \multicolumn{2}{|c|}{ 95\% Wald Confidence Interval } \\
\cline { 4 - 5 } & & & \multicolumn{1}{|c|}{ Lower } & Upper \\
\hline G & 3.37 & .468 & 2.56 & 4.42 \\
M & 4.69 & .536 & 3.75 & 5.87 \\
S & 6.87 & .641 & 5.72 & 8.25 \\
\hline
\end{tabular}


Pairwise Comparisons

\begin{tabular}{|c|c|c|c|c|c|c|c|}
\hline \multirow[t]{2}{*}{ (I) Community } & \multirow[t]{2}{*}{ (J) Community } & \multirow[t]{2}{*}{$\begin{array}{c}\text { Mean } \\
\text { Difference (I-J) }\end{array}$} & \multirow[t]{2}{*}{ Std. Error } & \multirow[t]{2}{*}{$\mathrm{df}$} & \multirow[t]{2}{*}{ Sig. } & \multicolumn{2}{|c|}{$\begin{array}{l}\text { 95\% Wald Confidence Interval } \\
\text { for Difference } \\
\end{array}$} \\
\hline & & & & & & Lower & Upper \\
\hline \multirow{2}{*}{$G$} & $\mathrm{M}$ & -1.32 & .711 & 1 & .063 & -2.72 & .07 \\
\hline & $\mathrm{S}$ & $-3.50^{\mathrm{a}}$ & .793 & 1 & .000 & -5.06 & -1.95 \\
\hline \multirow{3}{*}{ M } & $\mathrm{G}$ & 1.32 & .711 & 1 & .063 & -.07 & 2.72 \\
\hline & $\mathrm{S}$ & $-2.18^{\mathrm{a}}$ & .835 & 1 & .009 & -3.82 & -.54 \\
\hline & G & $3.50^{\mathrm{a}}$ & .793 & 1 & .000 & 1.95 & 5.06 \\
\hline $\mathrm{S}$ & $M$ & $2.18^{\mathrm{a}}$ & .835 & 1 & .009 & .54 & 3.82 \\
\hline
\end{tabular}

Pairwise comparisons of estimated marginal means based on the original scale of dependent variable Peromyscusmaniculatus a. The mean difference is significant at the .05 level.

Overall Test Results

\begin{tabular}{|c|c|c|}
\hline $\begin{array}{c}\text { Wald Chi- } \\
\text { Square }\end{array}$ & df & \multicolumn{1}{c|}{ Sig. } \\
\hline 19.511 & & 2 \\
\hline
\end{tabular}

The Wald chi-square tests the effect of Community. This test is based on the linearly independent pairwise comparisons among the estimated marginal means. 
Estimated Marginal Means 3: Treatment* Community

Estimates

\begin{tabular}{|c|c|c|c|c|c|}
\hline \multirow[t]{2}{*}{ Treatment } & \multirow[t]{2}{*}{ Community } & \multirow[t]{2}{*}{ Mean } & \multirow[t]{2}{*}{ Std. Error } & \multicolumn{2}{|c|}{ 95\% Wald Confidence Interval } \\
\hline & & & & Lower & Upper \\
\hline \multirow{4}{*}{ G } & $\mathrm{G}$ & 1.89 & .458 & 1.17 & 3.04 \\
\hline & M & 7.33 & .903 & 5.76 & 9.33 \\
\hline & $\mathrm{S}$ & 4.67 & .720 & 3.45 & 6.31 \\
\hline & $\mathrm{G}$ & 6.00 & .816 & 4.60 & 7.83 \\
\hline \multirow[t]{2}{*}{$\mathrm{N}$} & M & 3.00 & .577 & 2.06 & 4.37 \\
\hline & $\mathrm{S}$ & 10.11 & 1.060 & 8.23 & 12.42 \\
\hline
\end{tabular}


Pairwise Comparisons

\begin{tabular}{|c|c|c|c|c|c|c|c|}
\hline \multirow[t]{2}{*}{ (I) Treatment*Community } & \multirow[t]{2}{*}{ (J) Treatment*Community } & \multirow{2}{*}{$\begin{array}{c}\text { Mean } \\
\text { Difference } \\
(\mathrm{I}-\mathrm{J})\end{array}$} & \multirow[t]{2}{*}{$\begin{array}{l}\text { Std. } \\
\text { Error }\end{array}$} & \multirow[t]{2}{*}{$\mathrm{df}$} & \multirow[t]{2}{*}{ Sig. } & \multicolumn{2}{|c|}{$\begin{array}{l}\text { 95\% Wald Confidence } \\
\text { Interval for Difference }\end{array}$} \\
\hline & & & & & & Lower & Upper \\
\hline & $\begin{array}{l}\text { [Treatment }=\mathrm{G}] *[\text { Communit } \\
\mathrm{y}=\mathrm{M}]\end{array}$ & $-5.44^{\mathrm{a}}$ & 1.012 & 1 & .000 & -7.43 & -3.46 \\
\hline & $\begin{array}{l}{[\text { Treatment }=G] *[\text { Communit }} \\
\mathrm{y}=\mathrm{S}]\end{array}$ & $-2.78^{\mathrm{a}}$ & .853 & 1 & .001 & -4.45 & -1.11 \\
\hline \multirow[t]{5}{*}{$\begin{array}{l}{[\text { Treatment }=G] *[\text { Communit }} \\
\mathrm{y}=\mathrm{G}]\end{array}$} & $\begin{array}{l}{[\text { Treatment }=\mathrm{N}] *[\text { Communit }} \\
\mathrm{y}=\mathrm{G}]\end{array}$ & $-4.11^{\mathrm{a}}$ & .936 & 1 & .000 & -5.95 & -2.28 \\
\hline & $\begin{array}{l}\text { [Treatment }=\mathrm{N}] *[\text { Communit } \\
\mathrm{y}=\mathrm{M}]\end{array}$ & -1.11 & .737 & 1 & .132 & -2.56 & .33 \\
\hline & $\begin{array}{l}{[\text { Treatment }=N] *[\text { Communit }} \\
\mathrm{y}=\mathrm{S}]\end{array}$ & $-8.22^{\mathrm{a}}$ & 1.155 & 1 & .000 & -10.49 & -5.96 \\
\hline & $\begin{array}{l}\text { [Treatment }=\mathrm{G}] *[\text { Communit } \\
\mathrm{y}=\mathrm{G}]\end{array}$ & $5.44^{\mathrm{a}}$ & 1.012 & 1 & .000 & 3.46 & 7.43 \\
\hline & $\begin{array}{l}\text { [Treatment }=\mathrm{G}] *[\text { Communit } \\
\mathrm{y}=\mathrm{S}]\end{array}$ & $2.67^{\mathrm{a}}$ & 1.155 & 1 & .021 & .40 & 4.93 \\
\hline \multirow[t]{3}{*}{$\begin{array}{l}{[\text { Treatment }=G] *[\text { Communit }} \\
\mathrm{y}=\mathrm{M}]\end{array}$} & $\begin{array}{l}\text { [Treatment }=N] *[\text { Communit } \\
\mathrm{y}=\mathrm{G}]\end{array}$ & 1.33 & 1.217 & 1 & .273 & -1.05 & 3.72 \\
\hline & $\begin{array}{l}\text { [Treatment }=N] *[\text { Communit } \\
\mathrm{y}=\mathrm{M}]\end{array}$ & $4.33^{\mathrm{a}}$ & 1.072 & 1 & .000 & 2.23 & 6.43 \\
\hline & $\begin{array}{l}{[\text { Treatment }=N] *[\text { Communit }} \\
\mathrm{y}=\mathrm{S}]\end{array}$ & $-2.78^{\mathrm{a}}$ & 1.392 & 1 & .046 & -5.51 & -.05 \\
\hline $\begin{array}{l}{[\text { Treatment }=\mathrm{G}] *[\text { Communit }} \\
\mathrm{y}=\mathrm{S}]\end{array}$ & $\begin{array}{l}\text { [Treatment }=\mathrm{G}] *[\text { Communit } \\
\mathrm{y}=\mathrm{G}]\end{array}$ & $2.78^{\mathrm{a}}$ & .853 & 1 & .001 & 1.11 & 4.45 \\
\hline
\end{tabular}




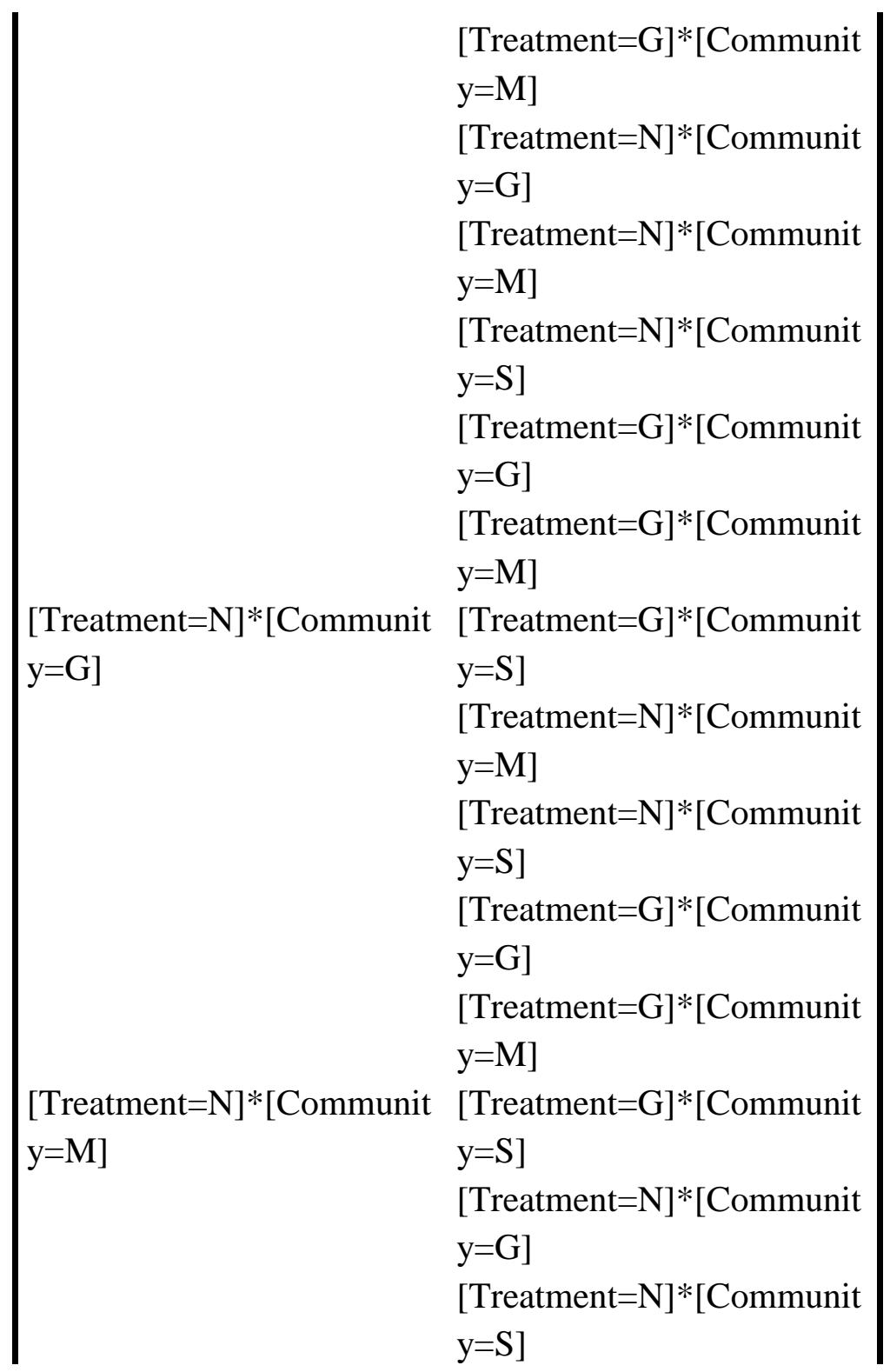

\begin{tabular}{|c|c|c|c|c|c|}
\hline$-2.67^{\mathrm{a}}$ & 1.155 & 1 & .021 & -4.93 & -.40 \\
\hline-1.33 & 1.089 & 1 & .221 & -3.47 & .80 \\
\hline 1.67 & .923 & 1 & .071 & -.14 & 3.48 \\
\hline$-5.44^{a}$ & 1.281 & 1 & .000 & -7.96 & -2.93 \\
\hline $4.11^{\mathrm{a}}$ & .936 & 1 & .000 & 2.28 & 5.95 \\
\hline-1.33 & 1.217 & 1 & .273 & -3.72 & 1.05 \\
\hline 1.33 & 1.089 & 1 & .221 & -.80 & 3.47 \\
\hline $3.00^{\mathrm{a}}$ & 1.000 & 1 & .003 & 1.04 & 4.96 \\
\hline$-4.11^{\mathrm{a}}$ & 1.338 & 1 & .002 & -6.73 & -1.49 \\
\hline 1.11 & .737 & 1 & .132 & -.33 & 2.56 \\
\hline$-4.33^{a}$ & 1.072 & 1 & .000 & -6.43 & -2.23 \\
\hline-1.67 & .923 & 1 & .071 & -3.48 & .14 \\
\hline$-3.00^{\mathrm{a}}$ & 1.000 & 1 & .003 & -4.96 & -1.04 \\
\hline$-7.11^{\mathrm{a}}$ & 1.207 & 1 & .000 & -9.48 & -4.75 \\
\hline
\end{tabular}




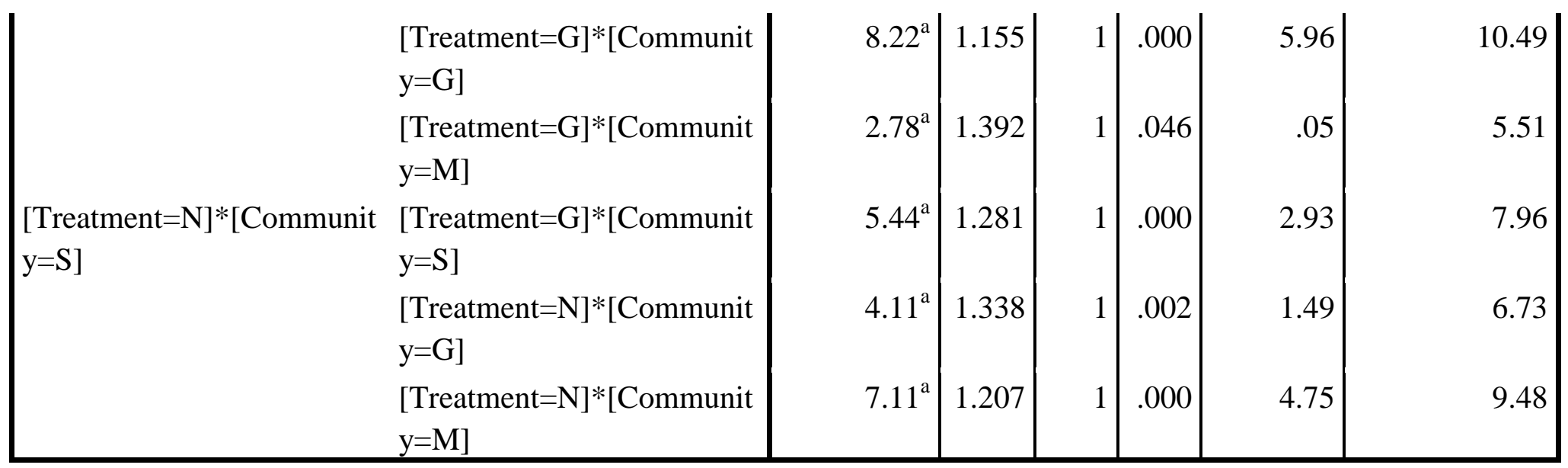

Pairwise comparisons of estimated marginal means based on the original scale of dependent variable Peromyscusmaniculatus

a. The mean difference is significant at the .05 level.

\begin{tabular}{|c|c|c|}
\hline \multicolumn{3}{|c|}{ Overall Test Results } \\
\hline $\begin{array}{l}\text { Wald Chi- } \\
\text { Square }\end{array}$ & $\mathrm{df}$ & Sig. \\
\hline 77.927 & 5 & .000 \\
\hline
\end{tabular}

The Wald chi-square tests the effect of

Treatment*Community. This test is based

on the linearly independent pairwise

comparisons among the estimated

marginal means. 


\section{Generalized Linear Models}

Model Information

Dependent Variable

Probability Distribution

Reithrodontomysmegalotis

Link Function

Poisson

Log

Case Processing Summary

\begin{tabular}{|l|l|l|}
\hline \multicolumn{1}{|c|}{} & $\mathrm{N}$ & Percent \\
\hline Included & 54 & $48.2 \%$ \\
Excluded & 58 & $51.8 \%$ \\
Total & 112 & $100.0 \%$ \\
\hline
\end{tabular}

Categorical Variable Information

\begin{tabular}{|c|c|c|c|c|}
\hline & & & $\mathrm{N}$ & Percent \\
\hline \multirow{7}{*}{ Factor } & \multirow{3}{*}{ Treatment } & $\bar{G}$ & 27 & $50.0 \%$ \\
\hline & & $\mathrm{N}$ & 27 & $50.0 \%$ \\
\hline & & Total & 54 & $100.0 \%$ \\
\hline & \multirow{4}{*}{ Community } & G & 18 & $33.3 \%$ \\
\hline & & M & 18 & 33.3\% \\
\hline & & S & 18 & $33.3 \%$ \\
\hline & & Total & 54 & $100.0 \%$ \\
\hline
\end{tabular}

Continuous Variable Information

\begin{tabular}{|ll|l|l|l|l|l|}
\hline & $\mathrm{N}$ & Minimum & Maximum & Mean & Std. Deviation \\
\hline Dependent Variable & Reithrodontomysmegalotis & 54 & 0 & 11 & 1.02 & 2.014 \\
\hline
\end{tabular}


Goodness of Fit ${ }^{\mathrm{a}}$

\begin{tabular}{|l|l|l|l|}
\hline & Value & df & Value/df \\
\hline Deviance & 115.152 & 48 & 2.399 \\
Scaled Deviance & 115.152 & 48 & \\
Pearson Chi-Square & 135.214 & 48 & 2.817 \\
Scaled Pearson Chi-Square & 135.214 & 48 & \\
Log Likelihood & -84.255 & & \\
Akaike's Information & 180.510 & & \\
Criterion (AIC) & & & \\
Finite Sample Corrected AIC & 182.298 & & \\
(AICC) & & & \\
Bayesian Information & 192.444 & & \\
Criterion (BIC) & & & \\
Consistent AIC (CAIC) & 198.444 & & \\
\hline
\end{tabular}

Dependent Variable: Reithrodontomysmegalotis

Model: (Intercept), Treatment, Community, Treatment *

Community

a. Information criteria are in small-is-better form.

b. The full log likelihood function is displayed and used in computing information criteria.

Omnibus Test $^{\mathrm{a}}$

\begin{tabular}{|l|l|l|}
\hline $\begin{array}{l}\text { Likelihood Ratio } \\
\text { Chi-Square }\end{array}$ & df & Sig. \\
\hline 27.101 & 5 & .000 \\
\hline
\end{tabular}

Dependent Variable:

Reithrodontomysmegalotis

Model: (Intercept), Treatment,

Community, Treatment * Community

a. Compares the fitted model against the intercept-only model.

Appendix E: Statistical Output 
Tests of Model Effects

\begin{tabular}{|l|l|l|l|}
\hline \multirow{2}{*}{ Source } & \multicolumn{3}{|l|}{ Type III } \\
\cline { 2 - 4 } & Wald Chi-Square & df & Sig. \\
\hline (Intercept) & 2.385 & 1 & .122 \\
Treatment & 3.679 & 1 & .055 \\
Community & 3.016 & 2 & .221 \\
Treatment * Community & 10.553 & 2 & .005 \\
\hline
\end{tabular}

Dependent Variable: Reithrodontomysmegalotis

Model: (Intercept), Treatment, Community, Treatment * Community 
Parameter Estimates

\begin{tabular}{|c|c|c|c|c|c|c|c|}
\hline \multirow[t]{2}{*}{ Parameter } & \multirow[t]{2}{*}{$B$} & \multirow[t]{2}{*}{ Std. Error } & \multicolumn{2}{|c|}{$\begin{array}{l}\text { 95\% Wald Confidence } \\
\text { Interval }\end{array}$} & \multicolumn{3}{|c|}{ Hypothesis Test } \\
\hline & & & Lower & Upper & $\begin{array}{l}\text { Wald Chi- } \\
\text { Square }\end{array}$ & df & Sig. \\
\hline (Intercept) & -.811 & .5000 & -1.791 & .169 & 2.630 & 1 & .105 \\
\hline [Treatment $=\mathrm{G}$ ] & .811 & 6009 & -.367 & 1.989 & 1.821 & 1 & .177 \\
\hline [Treatment=N] & $0^{\mathrm{a}}$ & & & & & & \\
\hline [Community=G] & 1.658 & 5455 & .589 & 2.727 & 9.239 & 1 & .002 \\
\hline [Community=M] & 1.012 & .5839 & -.133 & 2.156 & 3.002 & 1 & .083 \\
\hline$[$ Community $=\mathrm{S}]$ & $0^{\mathrm{a}}$ & & & & & & \\
\hline$[$ Treatment $=\mathrm{G}] *$ & -3.855 & 1.1869 & -6.182 & -1.529 & 10.552 & 1 & .001 \\
\hline$[$ Community=G] & & & & & & & \\
\hline$[$ Treatment=G] $*$ & -1.012 & .7504 & -2.482 & .459 & 1.817 & 1 & .178 \\
\hline [Community=M] & & & & & & & \\
\hline$[$ Treatment=G] $*$ & $0^{\mathrm{a}}$ & & & & & & \\
\hline$[$ Community=S] & & & & & & & \\
\hline$[$ Treatment $=\mathrm{N}] *$ & $0^{\mathrm{a}}$ & & & & & & \\
\hline$[$ Community=G] & & & & & & & \\
\hline$[$ Treatment $=\mathrm{N}] *$ & $0^{\mathrm{a}}$ & & & & & & \\
\hline [Community=M] & & & & & & & \\
\hline$[$ Treatment $=\mathrm{N}] *$ & $0^{\mathrm{a}}$ & & & & & & \\
\hline$[$ Community=S] & & & & & & & \\
\hline (Scale) & $1^{\mathrm{b}}$ & & & & & & \\
\hline
\end{tabular}

Dependent Variable: Reithrodontomysmegalotis

Model: (Intercept), Treatment, Community, Treatment * Community

a. Set to zero because this parameter is redundant.

b. Fixed at the displayed value. 
Estimated Marginal Means 1: Treatment

Estimates

\begin{tabular}{|c|c|c|c|c|}
\hline \multirow[t]{2}{*}{ Treatment } & \multirow[t]{2}{*}{ Mean } & \multirow[t]{2}{*}{ Std. Error } & \multicolumn{2}{|c|}{ 95\% Wald Confidence Interval } \\
\hline & & & Lower & Upper \\
\hline $\begin{array}{l}\mathrm{G} \\
\mathrm{N}\end{array}$ & $\begin{array}{l}48 \\
1.08\end{array}$ & $\begin{array}{l}.177 \\
.225\end{array}$ & $\begin{array}{l}.23 \\
.72\end{array}$ & $\begin{array}{l}.99 \\
1.63\end{array}$ \\
\hline
\end{tabular}

Pairwise Comparisons

\begin{tabular}{|ll|l|l|l|l|l|l|}
\hline (I) Treatment & (J) Treatment & $\begin{array}{l}\text { Mean Difference } \\
\text { (I-J) }\end{array}$ & & Std. Error & df & $\begin{array}{l}\text { Bonferroni } \\
\text { Sig. }\end{array}$ & \multicolumn{2}{|l|}{$\begin{array}{l}\text { 95\% Wald Confidence Interval } \\
\text { for Difference }\end{array}$} \\
\cline { 5 - 8 } & & & & & Lower & Upper \\
\hline $\mathrm{G}$ & $\mathrm{N}$ & $-.60^{\mathrm{a}}$ & .286 & 1 & .036 & -1.16 & -.04 \\
$\mathrm{~N}$ & $\mathrm{G}$ & $.60^{\mathrm{a}}$ & .286 & 1 & .036 & .04 & 1.16 \\
\hline
\end{tabular}

Pairwise comparisons of estimated marginal means based on the original scale of dependent variable Reithrodontomysmegalotis

a. The mean difference is significant at the .05 level.

Overall Test Results

\begin{tabular}{|l|l|l|}
\hline Wald Chi-Square & df & Sig. \\
\hline 4.415 & 1 & .036 \\
\hline
\end{tabular}

The Wald chi-square tests the effect of

Treatment. This test is based on the

linearly independent pairwise comparisons

among the estimated marginal means. 
Estimated Marginal Means 2: Community

Estimates

\begin{tabular}{|l|l|l|l|l|}
\hline Community & Mean & \multirow{2}{*}{ Std. Error } & \multicolumn{3}{|c|}{$95 \%$ Wald Confidence Interval } \\
\cline { 4 - 5 } & & & Lower & Upper \\
\hline $\mathrm{G}$ & .51 & .261 & .19 & 1.39 \\
$\mathrm{M}$ & 1.11 & .248 & .71 & 1.72 \\
$\mathrm{~S}$ & .67 & .200 & .37 & 1.20 \\
\hline
\end{tabular}

Pairwise Comparisons

\begin{tabular}{|c|c|c|c|c|c|c|c|}
\hline \multirow[t]{2}{*}{ (I) Community } & \multirow[t]{2}{*}{$\begin{array}{l}\text { (J) } \\
\text { Community }\end{array}$} & \multirow[t]{2}{*}{$\begin{array}{l}\text { Mean Difference } \\
(\mathrm{I}-\mathrm{J})\end{array}$} & \multirow[t]{2}{*}{$\begin{array}{l}\text { Std. } \\
\text { Error }\end{array}$} & \multirow[t]{2}{*}{ df } & \multicolumn{3}{|c|}{\begin{tabular}{l|l} 
Bonferroni $95 \%$ Wald Confidence Interval fol \\
Sig. & Difference \\
\end{tabular}} \\
\hline & & & & & & Lower & Upper \\
\hline \multirow{6}{*}{$\mathbb{M}$} & $\mathrm{M}$ & -.60 & .360 & 1 & .293 & -1.46 & .27 \\
\hline & S & -.16 & .329 & 1 & 1.000 & -.94 & .63 \\
\hline & $\mathrm{G}$ & .60 & .360 & 1 & .293 & -.27 & 1.46 \\
\hline & $\mathrm{S}$ & .44 & 319 & 1 & .507 & -.33 & 1.20 \\
\hline & G & .16 & .329 & 1 & 1.000 & -.63 & .94 \\
\hline & $\mathrm{M}$ & -.44 & .319 & 1 & .507 & -1.20 & .33 \\
\hline
\end{tabular}

Pairwise comparisons of estimated marginal means based on the original scale of dependent variable Reithrodontomysmegalotis 
Overall Test Results

\begin{tabular}{|l|l|l|}
\hline Wald Chi-Square & df & Sig. \\
\hline 3.075 & 2 & .215 \\
\hline
\end{tabular}

The Wald chi-square tests the effect of

Community. This test is based on the

linearly independent pairwise comparisons

among the estimated marginal means.

Estimated Marginal Means 3: Treatment* Community

Estimates

\begin{tabular}{|ll|l|l|l|l|}
\hline Treatment & Community & Mean & Std. Error & \multicolumn{2}{|l|}{ |s\% Wald Confidence Interval } \\
\cline { 5 - 6 } & & & & Lower & Upper \\
\hline \multirow{3}{*}{$\mathrm{G}$} & $\mathrm{G}$ & .11 & .111 & .02 & .79 \\
& $\mathrm{M}$ & 1.00 & .333 & .52 & 1.92 \\
& $\mathrm{~S}$ & 1.00 & .333 & .52 & 1.92 \\
$\mathrm{~N}$ & $\mathrm{G}$ & 2.33 & .509 & 1.52 & 3.58 \\
& $\mathrm{M}$ & 1.22 & .369 & .68 & 2.21 \\
& $\mathrm{~S}$ & .44 & .222 & .17 & 1.18 \\
\hline
\end{tabular}


Pairwise Comparisons

\begin{tabular}{|c|c|c|c|c|c|c|c|}
\hline \multirow[t]{2}{*}{ (I) Treatment*Community } & \multirow[t]{2}{*}{ (J) Treatment*Community } & \multirow{2}{*}{$\begin{array}{l}\text { Mean } \\
\text { Difference } \\
(\mathrm{I}-\mathrm{J})\end{array}$} & \multirow[t]{2}{*}{$\begin{array}{l}\text { Std. } \\
\text { Error }\end{array}$} & \multirow[t]{2}{*}{$\mathrm{df}$} & \multicolumn{3}{|c|}{\begin{tabular}{l|l} 
Bonfer & $95 \%$ Wald Confidence \\
roni & Interval for Difference \\
\end{tabular}} \\
\hline & & & & & & Lower & Upper \\
\hline & $\begin{array}{l}\text { [Treatment }=\mathrm{G}] *[\text { Community } \\
=\mathrm{M}]\end{array}$ & -.89 & .351 & 1 & .171 & -1.92 & .14 \\
\hline & $\begin{array}{l}\text { [Treatment }=\mathrm{G}] *[\text { Community } \\
=\mathrm{S}]\end{array}$ & -.89 & .351 & 1 & .171 & -1.92 & .14 \\
\hline \multirow[t]{5}{*}{$\begin{array}{l}{[\text { Treatment }=\mathrm{G}] *[\text { Community }} \\
=\mathrm{G}]\end{array}$} & $\begin{array}{l}\text { [Treatment }=\mathrm{N}] *[\text { Community } \\
=\mathrm{G}]\end{array}$ & $-2.22^{\mathrm{a}}$ & .521 & 1 & .000 & -3.75 & -.69 \\
\hline & $\begin{array}{l}\text { [Treatment }=\mathrm{N}] *[\text { Community } \\
=\mathrm{M}]\end{array}$ & -1.11 & .385 & 1 & .058 & -2.24 & .02 \\
\hline & $\begin{array}{l}{[\text { Treatment }=\mathrm{N}] *[\text { Community }} \\
=\mathrm{S}]\end{array}$ & -.33 & .248 & 1 & 1.000 & -1.06 & .40 \\
\hline & $\begin{array}{l}\text { [Treatment }=\mathrm{G}] *[\text { Community } \\
=\mathrm{G}]\end{array}$ & .89 & .351 & 1 & .171 & -.14 & 1.92 \\
\hline & $\begin{array}{l}\text { [Treatment }=\mathrm{G}] *[\text { Community } \\
=\mathrm{S}]\end{array}$ & .00 & .471 & 1 & 1.000 & -1.38 & 1.38 \\
\hline \multirow[t]{4}{*}{$\begin{array}{l}{[\text { Treatment }=\mathrm{G}] *[\text { Community }} \\
=\mathrm{M}]\end{array}$} & $\begin{array}{l}\text { [Treatment }=\mathrm{N}] *[\text { Community } \\
=\mathrm{G}]\end{array}$ & -1.33 & .609 & 1 & .427 & -3.12 & .45 \\
\hline & $\begin{array}{l}{[\text { Treatment }=\mathrm{N}] *[\text { Community }} \\
=\mathrm{M}]\end{array}$ & -.22 & .497 & 1 & 1.000 & -1.68 & 1.24 \\
\hline & $\begin{array}{l}{[\text { Treatment }=\mathrm{N}] *[\text { Community }} \\
=\mathrm{S}]\end{array}$ & .56 & .401 & 1 & 1.000 & -.62 & 1.73 \\
\hline & $\begin{array}{l}{[\text { Treatment }=\mathrm{G}] *[\text { Community }} \\
=\mathrm{G}]\end{array}$ & .89 & .351 & 1 & .171 & -.14 & 1.92 \\
\hline$=\mathrm{S}]$ & $\begin{array}{l}\text { [Treatment }=\mathrm{G}] *[\text { Community } \\
=\mathrm{M}]\end{array}$ & .00 & .471 & 1 & 1.000 & -1.38 & 1.38 \\
\hline
\end{tabular}




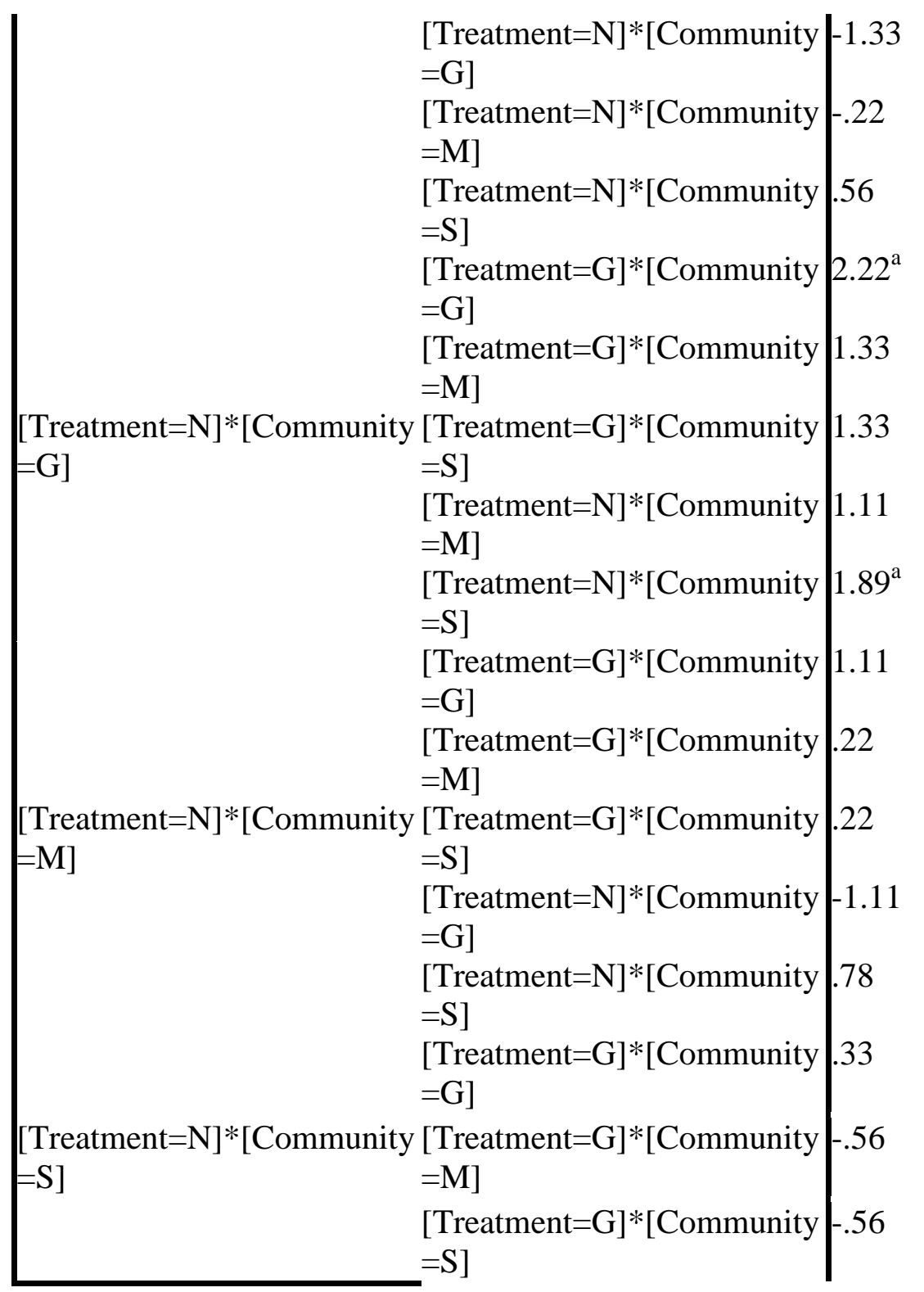

\begin{tabular}{|l|l|l|l|l}
.609 & 1 & .427 & -3.12 & .45 \\
.497 & 1 & 1.000 & -1.68 & 1.24 \\
.401 & 1 & 1.000 & -.62 & 1.73 \\
.521 & 1 & .000 & .69 & 3.75 \\
.609 & 1 & .427 & -.45 & 3.12 \\
.609 & 1 & .427 & -.45 & 3.12 \\
.629 & 1 & 1.000 & -.73 & 2.96 \\
.556 & 1 & .010 & .26 & 3.52 \\
.385 & 1 & .058 & -.02 & 2.24 \\
.497 & 1 & 1.000 & -1.24 & 1.68 \\
.497 & 1 & 1.000 & -1.24 & 1.68 \\
.629 & 1 & 1.000 & -2.96 & .73 \\
.430 & 1 & 1.000 & -.49 & 2.04 \\
.248 & 1 & 1.000 & -.40 & 1.06 \\
.401 & 1 & 1.000 & -1.73 & .62 \\
.401 & 1 & 1.000 & -1.73 & .62 \\
\hline
\end{tabular}

Appendix E: Statistical Output 


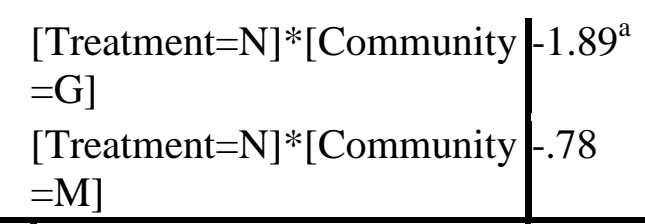

\begin{tabular}{ll|l|l|l}
.556 & 1 & .010 & -3.52 \\
.430 & 1 & 1.000 & -2.04 \\
\hline
\end{tabular}

$-.26$

Pairwise comparisons of estimated marginal means based on the original scale of dependent variable

Reithrodontomysmegalotis

a. The mean difference is significant at the .05 level.

Overall Test Results

\begin{tabular}{|l|l|l|}
\hline Wald Chi-Square & df & Sig. \\
\hline 32.650 & 5 & .000 \\
\hline
\end{tabular}

The Wald chi-square tests the effect of

Treatment*Community. This test is based

on the linearly independent pairwise

comparisons among the estimated marginal means. 